\title{
REVEALING MEMORY
}

Rehabilitating Pedestrian Experience at The Central Experimental Farm

By Hillary Little

A thesis submitted to the Faculty of Graduate and Postdoctoral Affairs

in partial fulfilment of the requirements for the degree of

\author{
Master of Architecture
}

Azrieli School of Architecture \& Urbanism

Carleton University

Ottawa, Ontario

(C) 2017

Hillary Little 


\begin{abstract}
The landscape is one of the richest historical records available to us. A mirror of our beliefs, ideologies, and memories - each layer is gradually built up over time, contributing to the complex spirit of place. By learning to read the landscape we can begin to pull apart these layers of time, revealing memory, and therefore enabling us to better understand ourselves and our history. This thesis proposes the reading of a monumental cultural landscape in the heart of the Nation's Capital: The Central Experimental Farm. A unique mix of national heritage, scientific legacy, and active research landscape, the Farm provides a multitude of ecological, economic, social, recreational, and educational opportunities to Ottawa. By investigating the complex layers of this cultural landscape, this thesis seeks to share those discoveries through a renewed pedestrian experience throughout the Farm, ensuring the resilience and longevity of this historic landscape in the face of change.
\end{abstract}




\section{Acknowledgements}

Thank you to my advisor, Mariana Esponda, for introducing me to the world of heritage conservation and for all your encouragement throughout this year. Thank you to the many heritage professionals and community organizations for sharing your passion and insights on the Farm. Thank you to all the staff and faculty for your guidance throughout all my years at the Azrieli School of Architecture and Urbanism. And finally, thank you to my family and friends - you are my rocks. 


\section{Prologue}

For several years I lived around the periphery of the Central Experimental Farm. First on Baseline Road, and second in a high-rise apartment on Fisher Avenue. Having not been native to Ottawa I knew little of this experimental farm, but found its open fields intriguing. Perhaps for their reminiscence of my home in Southwestern Ontario, or perhaps for their mysterious position in the centre of the city. Regardless, a fascination with the place began, as did regular walks and bikes through the site to get to Carleton University, and morning jogs around its farm roads. Despite the enjoyment of the Farm's spaces on most days, the Farm had its challenges: some walks were rendered impossible due to high winds or deep snow, the presence of an unwelcomeness due to the stares of the circulating security vehicles, and confusion; because I had no idea purpose of this farm or how it had come to be in the middle of our Capital city. In 2014, when talk of the hospital expansion onto the site arose, I was struck by the possible disappearance of this place I have come to enjoy. Through this thesis, I hope to protect and enhance those experiences which I have come to know and appreciate greatly about the Farm, as well as remediate those obstacles which prove frustrating for the place. I believe the Farm is a valuable part of Ottawa's heritage, and has the potential to become an oasis in the heart of our city. 


\section{Table of Contents}

Abstract

Acknowledgements iii

Prologue iv

Table of Contents $\mathrm{V}$

List of Illustrations vi

$\begin{array}{lr}\text { Introduction } & 9\end{array}$

Part One THEORY

1.1 Landscape as Cultural Construct 16

1.2 Cultural Landscapes 18

1.3 The Conservation of Historic Landscapes 20

Part Two NATIONAL CONTEXT

2.1 The Dominion Experimental Farm System 27

2.2 Research at the Farm 31

2.3 Agricultural Landscapes of Canada 36

2.4 Memory of the Agricultural Landscape 40

Part Three SITE CONTEXT

3.1 Existing Context 44

3.2 History of the Landscape 51

3.3 Character Defining Elements $\quad 70$

3.4 Existing Pedestrian Experience 71

3.5 Precedent Study $\quad 74$

Part Four DESIGN PROPOSAL

4.1 Program $\quad 77$

$\begin{array}{ll}4.2 \text { Site Plan } & 79\end{array}$

4.3 The Memories 84

Conclusion

109

Bibliography

111 


\section{List of Illustrations}

Introduction

FIGURE $1 \quad$ View of Central Experimental Farm Looking East

MAP 1

MAP 2

FIGURE 2
Greater Ottawa and Gatineau Area

Ottawa And Gatineau Core

Forces Acting on Cultural Landscapes

\section{Part One}

FIGURE 1

FIGURE 2

FIGURE 3

FIGURE 4

FIGURE 5

FIGURE 6

FIGURE 7

\section{Part Two}

MAP 3

MAP 4

FIGURE 2

FIGURE 3

MAP 5
Defining Landscape

The Archimedes Palimpsest

Identity

The Farm's Evolution as a Cultural Landscape Conservation Actions

The Farm Compared to the Front Lawn of Parliament Hill. National Historic Site Plaque

Timeline of Establishment of Experimental Farm System

Experimental Farms Across Canada

Satellite Images of the Original Experimental Farms

Crop Map

Soil Varieties Map

First Generation Farm

Aerial Photo of Rural Ottawa

The Arable Lands vs. The Populated Areas of Canada

\section{Part Three}

MAP 1

FIGURE 1

MAP 2

FIGURE 2

$M A P 3$

FIGURE 3

FIGURE 4

FIGURE 5

FIGURE 6

$M A P 4$

FIGURE 7

MAP 5

FIGURE 8

FIGURE 9

Major Landscaped Zones

Farm Structures, Pasture, and Research Fields

Existing Program

Sir John Carling Building Cafeteria

Surrounding Context

Skyline of the Research Fields

View from Core Zone

View of Civic Hospital

View of Dow's Lake

Vehicular Transportation

NCC Scenic Driveway

Possible Future Development

Under-construction Sit John Carling Building

Proposed National Botanic Garden 


$\begin{array}{ll}\text { FIGURE 10 } & \text { Proposed Rapid-Transit System } \\ \text { FIGURE 11 } & \text { Surficial Geology } \\ \text { MAP 6 } & \text { Surficial Geology } \\ \text { FIGURE 12 } & \text { Urban Growth of Ottawa and Gatineau } \\ \text { FIGURE 13 } & \text { Thomas Clark Farm } \\ \text { FIGURE 14 } & \text { Labourers Who Transformed the Rough Landscape } \\ \text { MAP 7 } & \text { Land Use 1879 } \\ \text { FIGURE 14 } & \text { Model Farm Set in a Picturesque Landscape } \\ \text { FIGURE 15 } & \text { The Ornamental Gardens in the Late 1880's } \\ \text { FIGURE 16 } & \text { 1903 Todd Plan } \\ \text { MAP 8 } & \text { Land Use 1886 } \\ \text { FIGURE 17 } & \text { The Saunders' Building } \\ \text { FIGURE 18 } & \text { The NCC Driveway in the 1950's } \\ \text { FIGURE 19 } & \text { Aerial View of Civic Hospital in 1924 } \\ \text { FIGURE 20 } & \text { Site Plan of Civic Hospital in 1965 } \\ \text { MAP 9 } & \text { Proposed Land Use 1950 Gréber Plan } \\ \text { MAP 10 } & \text { Land Use 1950 } \\ \text { MAP 11 } & \text { Land Use 1960's } \\ \text { FIGURE 21 } & \text { Inhabitants of The Site } \\ \text { FIGURE 22 } & \text { Journey Through the Site } \\ \text { FIGURE 23 } & \text { Types of Pathways } \\ \text { FIGURE 24 } & \text { Sohlbergplassen Viewpoint } \\ \text { FIGURE 25 } & \text { Aurland Lookout } \\ \text { FIGURE 26 } & \text { Tungeneset Rest Area } \\ \end{array}$

\section{Part Four}

FIGURE 1 Diagrammatic Site Plan

FIGURE 2 Conceptual Planning Relating to City

FIGURE 3 The Passage Sketch

FIGURE 4 The Passage Perspective

FIGURE 5 The Passage Diagram

FIGURE 6 The Clearing, the Meadow, and the Forest Sketch

FIGURE 7 The Clearing, the Meadow, and the Forest Perspective

FIGURE 8 The Clearing, the Meadow, and the Forest Diagram

FIGURE 9 The Swamp and the Shelterbelt Sketch

FIGURE 10 The Swamp and the Shelterbelt Perspective

FIGURE 11 The Swamp and the Shelterbelt Diagram

FIGURE 12 The Grave Sketch

FIGURE 13 The Grave Perspective

FIGURE 14 The Grave Diagram

FIGURE 15 The River and the Shelterbelt Sketch

FIGURE 16 The River and the Shelterbelt Perspective

FIGURE 17 The River and the Shelterbelt Diagram 


\section{Introduction}

Through an investigation into the inextricable link between landscape and memory, this thesis seeks to develop a design proposal advocating for the rehabilitation of the pedestrian experience throughout the Central Experimental Farm to protect this historic cultural landscape located in the heart of Canada's capital.

In the latter half of the nineteenth century, the federal government established a network of five experimental farms across Canada to support and improve agricultural production across the country. Each experimental farm was strategically placed in different growth regions across the Dominion; from the Maritimes to the Prairies, to the Okanagan Valley in the far west. The legacy of this network of Experimental Farms is indisputable. Since establishment, the Farms' research has significantly contributed to Canada's multi-billion dollar agri-food industry and continues to contribute today through ongoing research. Most notably, the Experimental Farms' greatest research contribution is adapting crops to Canadian soil and climate conditions, thus expanding agricultural production across Canada's vast territory. ${ }^{1}$

At the heart of these experimental research stations is Ottawa's Central Experimental Farm (The Farm), established in 1886. The first to be established, it became the directing and coordinating centre to the network of experimental farms, while also providing specific agricultural knowledge to the Quebec and Ontario regions. ${ }^{2}$ Beginning as a model research farm located on the outskirts of the national Capital, the Farm has since become inextricably linked - both physically and metaphysically - to the surrounding city. The physical connections lie in its proximity to the surrounding urban fabric, where its metaphysical connections lie in its association as a place of ongoing scientific research and a place of National Historic value. The Farm possesses both cultural significances to the surrounding city as well as symbolic significances to the greater nation. The intersection of the physical and mental reality makes the Farm a rare cultural landscape in the national capital. The combination of its natural, built, and landscaped elements together designate the place a cultural landscape, from its variety of eclectic and picturesque structures, Arbouretum, gardens, to the vast expanses of research farmland. ${ }^{3}$ See FIGURE 1.

\footnotetext{
'Stephen Morgan Jones, "Agricultural Research Stations," The Canadian Encyclopedia, accessed December 02, 2016, http://www.thecanadianencyclopedia.ca/en/article/agricultural-research-stations/. 2 Ron Williams, Landscape Architecture in Canada (Montreal: McGill-Queen's University Press, 2014), 148. ${ }^{3}$ HistoricPlaces.ca - HistoricPlaces.ca, accessed January 02, 2017, http://www.historicplaces.ca/en/rep-reg/placelieu.aspx?id=13811.
} 


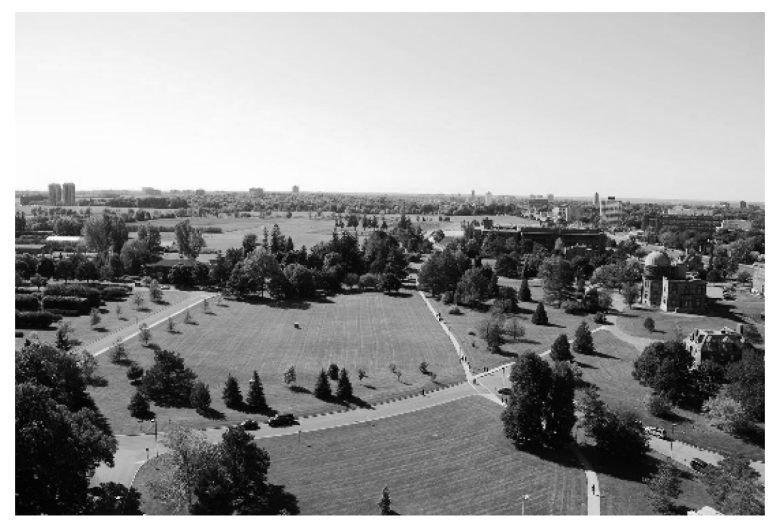

\section{| FIGURE 1}

View of Central Experimental Farm looking east (Photo: PFS Studio).

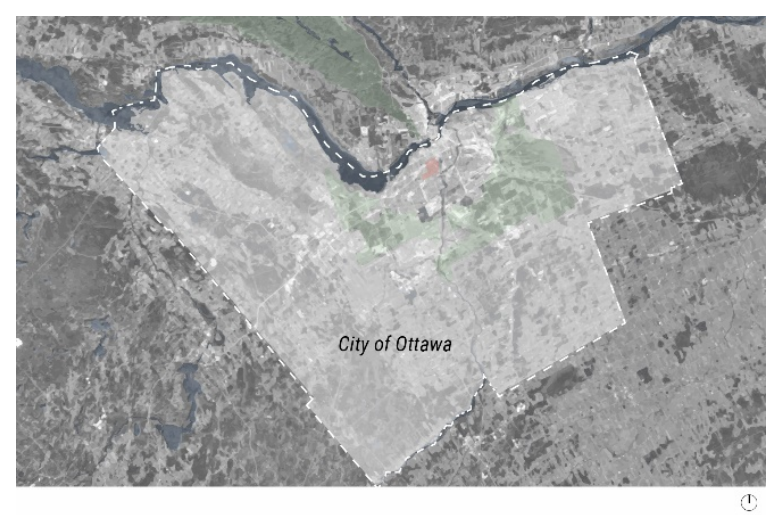

MAP 1

Greater Ottawa and Gatineau area.

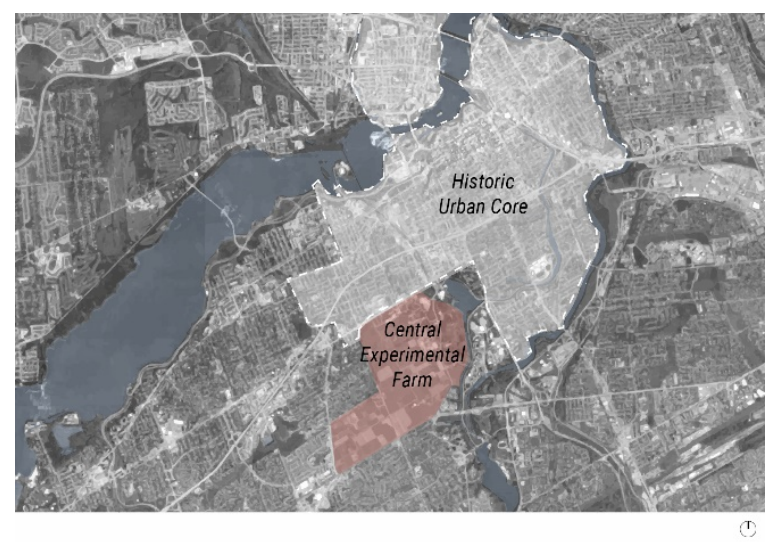

MAP 2

Ottawa and Gatineau core.

Within this 427-hectare (1,055 acres) landscape, which borders the UNESCO World Heritage Rideau Canal, are over 130 years of agricultural research, cultural events, and scientific achievement. However, perhaps greater than the activity of the last century on the landscape is the activity of the landscape of the time before the Farm. Various peoples have shared the 
lands of the Ottawa region for more than 10,000 years. As they evolved over time, their connections and interactions have shaped the land to reflect who they were as a society. Over time, as the land has transformed into a historic urban landscape, much of the before history has become hidden. This thesis will explore this palimpsest landscape to uncover the history, identity, and ultimately the forgotten memories of the previous landscapes. UNESCO's Recommendation on the Historic Urban Landscape (2011) advocates that urban heritage is an asset to our communities "defined by [a] historic layering of values that have been produced by successive and existing cultures and an accumulation of traditions and experiences, recognised as such in their diversity." " ${ }^{4}$ t is our duty to understand, protect, and interpret those layers to strengthen our communities, celebrate our diversity, and ensure the longevity of this historic landscape for future generations.

Cultural landscapes are defined as the "combined works of nature and of man. ${ }^{5}$ A relatively new aspect of heritage conservation and receiving only formal recognition in 1992 by the World Heritage Committee, cultural landscapes tell the story of human society and settlement throughout time. The key to the approach of conserving cultural landscapes is understanding the place over time and over an area. A holistic framework recognises that cultural landscapes can expand across a broad area and are continually under change due to several interrelated internal and external forces. They include the natural, socio-cultural, economic, and technical, making the management of these critical areas complex (FIGURE 2). These forces can act positively or pose threats to the landscapes. To ensure the appropriate management of the Farm as a cultural landscape, the Central Experimental Farm National Historic Site Management Plan was created in 2004 by Julian Smith Architects, Contentworks, and PFS Studio to guide this historic cultural landscape into the $21^{\text {st }}$ century. ${ }^{6}$ This thesis uses the Management Plan as a base to understand the components which aid in sustaining the Farm as a cultural landscape including its heritage value, character-defining elements, and proposed directions.

\footnotetext{
4 "Recommendation on the Historic Urban Landscape, including a glossary of definitions." Recommendation on the Historic Urban Landscape, including a glossary of definitions, accessed February 05, 2017. http://portal.unesco.org/en/ev.php-

URL_ID = 48857\&URL_DO=DO_TOPIC\&URL_SECTION=201.html.

5 Fowler, P. J. World Heritage Cultural Landscapes, 1992-2002. Article 1. Paris: UNESCO World Heritage Centre 2003.

6 "Central Experimental Farm." PFS Studio. Accessed January 02, 2017. http://pfsstudio.com/project/centralexperimental-farm/.
} 


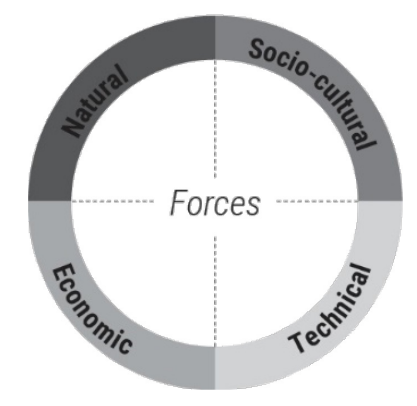

| FIGURE 2

Forces acting on cultural landscapes can be threats or opportunities.

The Management Plan concludes that the main challenge in maintaining the ongoing significance of the of the Farm is balancing its identities as a place of current scientific research and a place of national heritage. National Historic Sites are places which reflect the diverse heritage of Canada and invite Canadians to learn about their rich history, ${ }^{7}$ whereas a scientific landscape is one which requires a highly controlled environment to facilitate research. The two identities are diverse, and as mentioned previously, are present in both the physical and mental reality. This research aims to rehabilitate this increasingly complex relationship by allowing people to understand better and experience this place of national heritage while respecting the functional requirements of the site as an active research laboratory. The research will culminate in a design proposal for the Farm which aims to answer the following question:

How can architecture be employed to protect both the scientific research and national historic significance of the Central Experimental Farm in the present time and for future generations, while simultaneously expressing the tangible and intangible memory of the site?

7 Parks Canada Agency, Government of Canada. "Parks Canada - National Historic Sites - National Historic Sites." Parks Canada - National Historic Sites - National Historic Sites. February 14, 2017. Accessed March 02, 2017. http://www.pc.gc.ca/eng/progs//hn-nhs/index.aspx. 


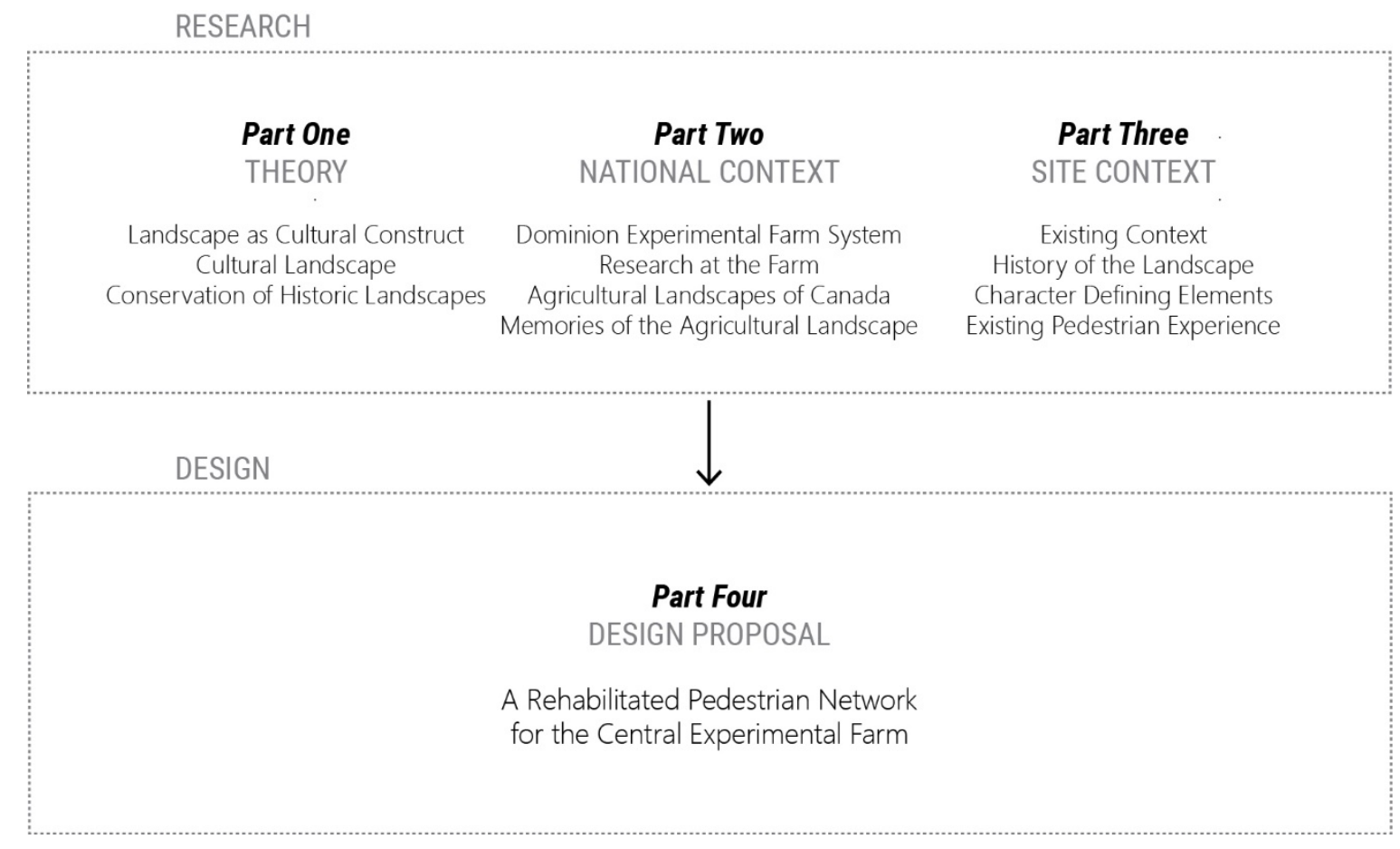




\section{Part One THEORY}

This part will explore and understand the link between our memory, identity, and sense of place as it relates to the landscape, and more specifically the landscape of our everyday lives. This part will also look at the evolvement of the study of cultural landscapes and their conservation, by understanding the importance of heritage places in strengthening communities, and the conservation steps which require consideration when intervening on historic landscapes.

\section{Part Two NATIONAL CONTEXT}

Part two will look at the impact of the national network of experimental research stations in expanding agriculture across the country as well as their present role in agricultural research. This part also explores the history of the agriculture and agri-food industry and its socio-economic impacts in Canada presently and historically - including methods which have been practised on the land for thousands of years versus the contrasting methods of European colonisers. This part will also look at Canadians relationship to rural and "natural" landscapes and their role in defining cultural memory and identity.

\section{Part Three SITE CONTEXT}

This part will investigate the landscape of the Farm before and after its establishment, through historical documents, photographs, maps, and the Central Experimental Farm National Historic Site Management Plan. This part will also understand the influences of the wider city on the Farm landscape, determine its heritage value, and character-defining elements. This part will also determine whether the forces acting on the Farm - the natural, socio-cultural, economic, and technical - are either threats or opportunities to prepare for the design proposal in Part Four.

\section{Part Four DESIGN PROPOSAL}

This section will illustrate the design proposal based on the findings and conclusions from the first three Parts. Throughout the first three parts FORCES, CHARACTER DEFINING ELEMENIS, and MEMORIES of importance are highlighted and used in forming the design proposal. The design proposal will seek to consolidate the research and national heritage identities of the Farm by employing the pedestrian experience as the mediator between these two identities. The rehabilitation of the pedestrian pathway network will respond to the current needs of the Farm and surrounding area and will aim to strengthen the future of the Farm.

\author{
FORCES \\ NATURAL \\ SOCIO-CULTURAL \\ ECONOMIC \\ TECHNICAL

\section{CHARACTER DEFINING ELEMENT} \\ EVIDENCE OF LAND USE \\ EVIDENCE OF TRADITIONAL PRACTICES \\ LAND PATTERNS \\ SPATIAL ORGANIZATION \\ VISUAL RELATIONSHIPS \\ CIRCULATION \\ ECOLOGICAL FEATURES \\ VEGETATION \\ LAND FORMS \\ WATER FEATURES \\ BUILT FEATURES
}

\section{MEMORY}

LOCAL

REGIONAL

NATIONAL 


\section{OBJECTIVE OF DESIGN PROPOSAL}

Furthermore, the architectural language of the pathways will bring forth the currently hidden or intangible memory of the agricultural landscape. The objectives of the design proposal are as follows:

I. This proposal seeks to balance and protect the identities of the Central Experimental Farm as both a National Historic Site and as an active research landscape, now and for future generations.

II. This proposal seeks to foster Ottawa's relationship with the Farm by improving upon pedestrian life and providing safe, accessible, and scenic pathways throughout the Farm.

III. This proposal seeks to make evident the uses and transformations of the agricultural landscape during and before Canada.

\section{UNDERSTANDING THE CONTEXT}

As stated in Ron William's Landscape Architecture in Canada, "landscapes of the past can only be fully understood in terms of the events and values of the times and places in which they were created." ${ }^{8}$ It is important when looking back on historic landscapes to decipher them within their own time. It is easy and often compulsory to impose today's values on the landscape of the past. However, landscape gives us the opportunity to look back on our history with an unobscured lens, allowing us to freely read our history thus enabling us to understand our own time better.

${ }^{8}$ Williams, 5 


\section{Part One}

1.1 Landscape as Cultural Construct

1.2 Cultural Landscapes

1.3 The Conservation of Historic Landscapes 


\subsection{Landscape as Cultural Construct}

\section{THE WORD ITSELF}

The long history and various definitions of the word landscape have frequently centred around two meanings. Firstly, space which has been shaped by humans, and secondly the interaction between the actual and mental images of the place. ${ }^{9}$ For centuries humans have associated themselves in both the physical and metaphysical reality of the land. From its Old English predecessor - landskipe - one can understand the first part of the word, land, as being a "well-defined portion of the earth's surface" (including a ploughed field or a sovereign territory). ${ }^{10}$ The suffix skipe is defined as a collection or composition of similar objects (FIGURE 1). By this definition, it appears landscape is a synthetic space. ${ }^{11}$ The landscape does not evolve purely under natural law but evolves under the intricately layered system of human created spaces. Therefore, the landscape does not exist as a passive backdrop to our lives, but rather is inextricably linked to every facet of our existence.

\section{LAYERS OF MEANING}

As we live within these created landscapes, they become embedded with meaning and significance, contributing to our identities of who we are. The association of events, people, or traditions can come to define meanings in the landscape. ${ }^{12}$ The ascribing of values to landscape is a common denominator for all humans as the need for a sense of belonging and identity is part of our innate nature. ${ }^{13}$ As Ken Taylor states in his paper Landscape and Memory presented at the $3^{\text {rd }}$ International Memory of the World Conference: "Landscape can ... be seen as a cultural construct in which our sense of place and memories inhere. ${ }^{\prime 14}$ As successive generations transform the landscape, reworking it to suit their needs and values, it resembles a palimpsest - a document written over multiple times showing visible traces of previous lives - with its layers of physical evidence, history, and memory. A palimpsest text or landscape displays the visible traces of the past, but what is no longer visible may hold as much weight as what still exists (FIGURE 2). "Its scenery is built up as much in from the strata of memory as from layers of rock." 15 Simon Shama acknowledges the weight of the intangible against the tangible and their superimposition upon one another in the landscape in his book Landscape and Memory.

\footnotetext{
${ }^{9}$ Chris Wilson and Paul E. Grith, Everyday America: Cultural Landscape Studies after J.B. Jackson (Berkeley: University of California Press, 2003), 2.

${ }^{10}$ J.B. Jackson. Discovering the Vernacular Landscape (New Haven: Yale University Press, 2009), 6.

${ }^{11}$ Ibid., 8.

12 Williams, 5.

${ }^{13}$ Ken Taylor, "Landscape and Memory" (paper presented at the UNESCO Third International Memory of the World Conference, Australia, February 19-22, 2008), 1.

${ }^{14}$ lbid., 1.

${ }^{15}$ Simon Schama, Landscape and Memory (London: HarperCollins, 1995), 6-7.
}

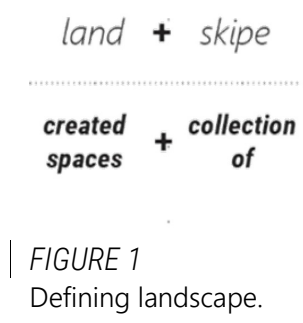

Defining landscape. 


\section{PLACE AND IDENTITY}

If landscapes are a cultural construct, a way of viewing the world, then they are more than "what we see, but a way of seeing." ${ }^{16}$ What we see every day extends beyond our eyes, into our minds, and becomes a part of our memories. Over time, the activities of our everyday weave the web of our identity - ordinary - but "ordinarily sacred."17 Thus crucial to the formation of identity - sense of place and therefore human meaning - are ordinary experiences. Canadian geographer, Edward Relph examines our relationship with everyday spaces in Place and Placelessness. Relph defines three types of everyday spatial experience: the pragmatic, perceptual, and the existential. These experiences contribute to the formation of place identity: the act of differentiating the "persistent sameness and unity" of a place from others. ${ }^{18}$ This identity of place is made up of three components: the physical, the activities, and meanings derived from experience. ${ }^{19}$ See FIGURE 3.

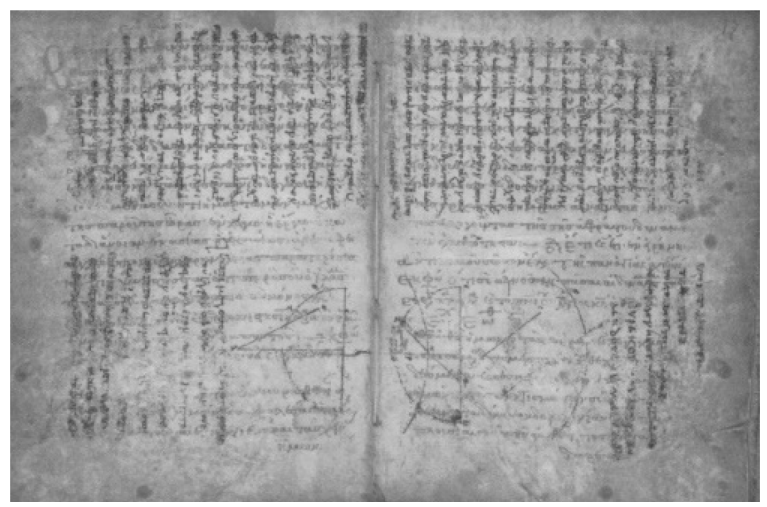

FIGURE 2

The Archimedes Palimpsest (Photo: https://dmwordoftheweek.wordpress.com/ 2014/04/25/palimpsest/).

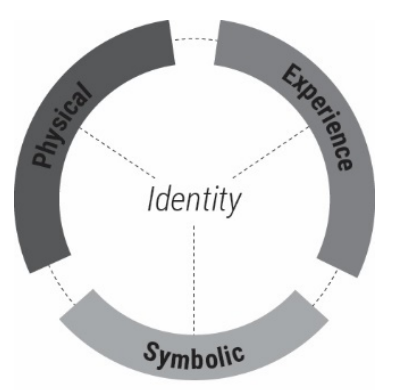

FIGURE 3

The formation of identity in determining a sense of place (as illustrated by Ken Taylor, 2008, based on Edward Relph, 1976).

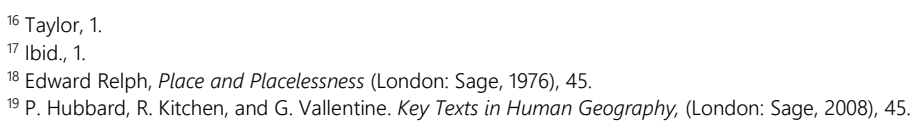




\subsection{Cultural Landscapes}

The fascination with the everyday web of interactions that make up human existence began to gain immense popularity in the late 1950's. Studies shifted away from individual buildings and landmark structures, towards the spaces between these structures, the built landscape, and the cultural frameworks in which they exist. ${ }^{20}$ Popularised by the writings of J.B. Jackson, the French-born, American naturalised writer, the term cultural landscape, or rather landscape as it is often referred to, came to describe the interaction of people and place. The concept of cultural landscape had been used before Jackson, particularly by cultural geographers. The formal use of the term occurred at the beginning of the $20^{\text {th }}$ century by Otto Schlüter, a German geographer who advocated to think of geography as the science of landscape: Landschaftskunde. He advocated for geographers to study the development of human cultures by looking at the cultural landscape: Kulturlandschaft. ${ }^{21}$

This concept was popularised in America in the 1920's and 30's by geographer Carl Sauer who was dissatisfied with the viewpoint of environmental determinism which was the dominant theory among his colleagues at the time. 22 Sauer believed the relationship between human beings and their environment was reciprocal; that humans had as much of an impact on their physical environments as it had on them. Sauer advocated instead: "the cultural landscape is fashioned out of a natural landscape by a cultural group." ${ }^{23}$ Sauer saw the cultural group as the mediator, the natural area as the medium, and the cultural landscape as a result. ${ }^{24}$ The overarching theme which remained common between these growing studies in cultural landscapes was that cultural landscapes exist at the interface of culture and nature. At this interface, there exists a complex web of scientific, political, social, ecological, and economic interactions present in both tangible and intangible realities. The study of these interactions promotes the visual literacy of the landscape, in effect fostering a deeper understanding of people and their cultures. This knowledge can be used to protect and manage the landscape today.

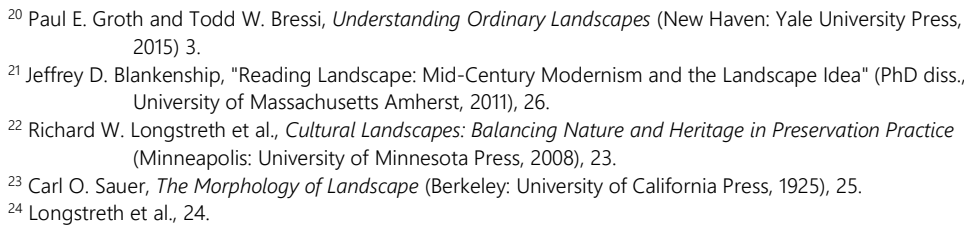

environmental determinism

A concept which argues that both general features and regional variations of human cultures and societies are determined by the physical and biological forms that make up the earth's many natural landscapes (John L. Brooke, Ohio State University). 
In 1982, ICOMOS adopted the Florence Charter as an addendum to the 1964 Venice Charter. The Florence Charter outlined the preservation of historic gardens: "an architectural and horticultural composition of interest to the public from the historical or artistic point of view. ${ }^{25}$ It acknowledged the importance of its plan, topography, vegetation (species, proportions, colour schemes, spacing, and heights), and structural and decorative feature as part of a composition of the whole.

25 The Florence Charter (London: ICOMOS UK, 1981), Article 1. 


\subsection{The Conservation of Historic Landscapes}

\section{THE EXPANDING DEFINITION OF HERITAGE PLACE}

Although the term cultural landscapes originated amongst geography professionals; architects, landscape architects, historians of the built environment, most commonly practice the preservation of these landscapes. ${ }^{26}$ In the last thirty years, cultural landscapes have been adopted by international legal organisations to ensure the protection and management of these historic places. In 1992, the $16^{\text {th }}$ session of the World Heritage Convention saw the first adoption of guidelines concerning their protection. As designated in Article 1 of the Convention, cultural landscapes represent "combined works of nature and of man."27 In keeping with international trends in the field of heritage conservation, Canada has also seen an expansion in their definition of historical place. The definition has expanded from single properties, to include a varying number of building types, historic districts, and finally to include cultural landscapes. Focus has shifted to "social history and the diverse people that have contributed to the country's development." ${ }^{28}$ In the last two decades, Parks Canada has begun to acknowledge significant places associated with Aboriginal history, cultural communities, and women's history. Canada now recognises the value of historic places for their contributions to sustainable and social development. As listed in UNESCO's Recommendation on the Historic Urban Landscape, the wider context of heritage conservation has expanded to include: the site's topography, geomorphology, hydrology, natural features, historic and contemporary built elements, above and below ground infrastructure, open spaces and gardens, land use patterns and spatial organization, perceptions and visual relationships, as well as all other elements of the urban setting. ${ }^{29}$ The context also includes the intangible elements of importance such as social and cultural practices and values, economic processes, and other elements related to diversity and identity. ${ }^{30}$ As determined in the previous section, all landscapes have a degree of culture embedded in them.

How can a landscape having cultural associations be distinguished from and a formally designated cultural landscape?

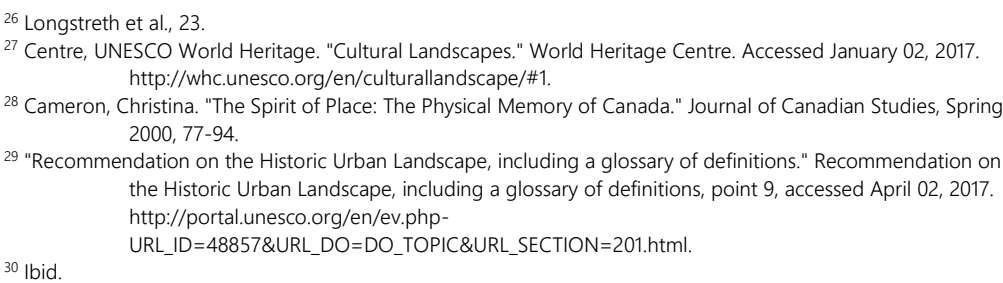

cultural landscape

1906 Human culture acting on the primeval [cultural] landscape through the medium of time (Otto Schlüter).

1925 The cultural landscape is fashioned from a natural landscape by a cultural group. Culture is the agent, the natural area is the medium, the cultural landscape is the result (Carl Sauer, The Morphology of Landscape).

1992 Combined works of nature and of man (WHC).

1994 A geographic area, including both cultural and natural resource and the wildlife or domestic animals therein, associated with a historic event, activity, or person or exhibiting other cultural or aesthetic values (U.S. Department of the Interior).

1999 A concrete and characteristic product of the interplay between a given human community, embodying certain cultural preferences and potentials, and a set of natural circumstances. It is a heritage of many eras of natural evolution and of many generations of human effort (Peter Fowler, Cultural landscape - Archaeology, Ancestors and Archive)

2004 A set of ideas and practices, embedded in a place. This definition is used to capture the relationship between the intangible and tangible qualities of these sites (National Capital Commission). 2010 Geographical area that has been modified, influenced or given special cultural meaning by people (The Standards and Guidelines). 


\section{CATEGORIES OF CULTURAL LANDSCAPES}

The Standards and Guidelines for the Conservation of Historic Places

in Canada and UNESCO World Heritage Committee agree that there are three categories of cultural landscapes: designed landscapes, evolved landscapes, and associative landscapes with many cultural landscapes encompassing more than one type simultaneously or at different times, and the shared understanding of the place differentiating between cultural groups. Urban heritage districts may also be considered cultural landscapes. The Farm encompasses all three categories of cultural landscape, beginning as a designed landscape, evolving to suit new times, and now has intangible associations with many different cultural groups and events (FIGURE 4). The Farm is also located in an urban area so can be considered a historic urban landscape.

\section{O designed landscape 1886-1936 \\ - evolved landscape 1936-1986 \\ - associative landscape \\ 1986 to Present}

FIGURE 4

The expanding definition of the Farm as a cultural landscape.

\section{METHODOLOGY}

The conservation of historic places is not about freezing the past in time, but rather is about understanding, protecting, and interpreting the rich layers which make up our history. As mentioned previously, UNESCO asserts in Recommendations on the Historic Urban Landscape (2011) that historic landscapes, such as the Central Experimental Farm, should be viewed as an asset to our community. There are many benefits to be gained from the preservation of historic landscapes including ecological, economic, scenic, social, recreational, and educational opportunities. ${ }^{31}$ As individuals, communities, and as a nation these opportunities help us to understand ourselves better, foster a sense of identity, and improve our lives, and the lives of future generations. ${ }^{32}$ Conserving our heritage landscapes now will ensure present, and future generations can discover, learn, and benefit from the "creativity, imagination, wisdom, and knowledge of our ancestors." 33

\footnotetext{
31 "Preservation Brief 36: Protecting Cultural Landscapes: Planning, Treatment and Management of Historic Landscapes." National Parks Service, accessed December 01, 2016. https://www.nps.gov/tps/howto-preserve/briefs/36-cultural-landscapes.htm.

32 lbid.

${ }^{33}$ Beth Hanna, "Voices of the Landscape." Heritage Matters, Heritage Trust Ontario 14, no. 2 (September 2016),
}

designed landscape

Encompass planning and creation by humans include examples such as gardens and parks. The originally imagined design is physically evident in the landscape.

associative landscape

Rely heavily on intangible evidence rather than physical evidence. Through intangible associations, the landscape illustrates a specific cultural region.

evolved landscape

Have organically responded to cultural forces and its natural environment. These changes over time are evident in their physical features. However, the traditional intentions of the place are still active. 
Various people have occupied the land known as Canada for more than 10,000 years, shaping and transforming the landscape - in varying capacities - but nonetheless successively accumulating tradition, experiences, and forming a connection with the landscape. The beliefs and ideologies of these diverse societies and their evolvement of the landscape over time should be protected, reflected, and celebrated in our communities. Landscapes are vast, complex, and extend beyond its visual components and into the minds and memories of people.

How do we protect a landscape?

\section{SPIRIT OF PLACE}

To protect a landscape, it is important first to understand its history including the people who inhabited the place, their beliefs, and their values, and most importantly understanding these aspects under the peoples' culture. $^{34}$ This complex relationship between culture and landscape is defined as the spirit of place, and as described in UNESCO's Declaration on the Protection of the Spirit of Place is as follows:

Spirit of place is defined as the tangible (buildings, sites, landscapes, routes, objects) and the intangible elements (memories, narratives, written documents, rituals, festivals, traditional knowledge, values, textures, colors, odors, etc.), that is to say the physical and the spiritual elements that give meaning, value, emotion and mystery to place. ${ }^{35}$

To safeguard the spirit of place within a cultural landscape threats must be identified, values must be protected, and meaning must be communicated to the public. ${ }^{36}$ This thesis will employ The Standards and Guidelines for the Conservation of Historic Places in Canada as a framework to appropriately investigate the Farm. The Standards and Guidelines, most recently revised in 2010, helps designers perform the most appropriate conservation practices when dealing with historic sites. ${ }^{37}$ It favours a "values-based context" on which to assess historic places and is "an essential tool to guide decisions that will give historic places new life while protecting their heritage value." ${ }^{38}$ The sequence of conservations actions is understanding, planning, and intervening. Although initially performed in that order, the conservation

\footnotetext{
${ }^{34}$ Hanna, 3.

35 "Quebec City Declaration on The Preservation of The Spirit of Place." Quebec 2008 ICOMOS. Accessed March ${ }^{36}$ Hanna, 2 15, 2017. http://quebec2008.icomos.org/en/99_intro_blog.htm.

${ }^{37}$ Standards and Guidelines for the Conservation of Historic Places in Canada: A Federal, Provincial and Territorial ${ }^{38}$ lbid., v. Collaboration, viii.
}

\footnotetext{
heritage value

The aesthetic, historic, scientific, cultural, social or spiritual importance or significance for past, present and future generations. The heritage value of an historic place is embodied in its character-defining materials, forms, location, spatial configurations, uses and cultural associations or meanings (Standards \& Guidelines).
} 
process is cyclical, as understood in FIGURE 5. Re-visiting steps to ensure appropriate actions is common. ${ }^{39}$ Below are the conservations actions are broken down to indicate where in this thesis each of the actions is addressed.

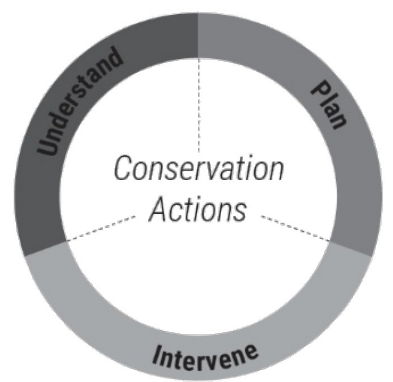

FIGURE 5

Conservation Actions (Standards \& Guidelines).

Understanding RESEARCH

Refer to Heritage Value and Character-defining Elements

Section 3.3

Investigate \& document condition \& change understanding

Section 3.1, 3.2, 3.4

\section{Planning DESIGN PROPOSAL}

Maintain or select an appropriate and sustainable use

Section 4.1

Identify project requirements

Section 4.1

Determine the primary treatment

Section 4.1

Review the standards

Section 4.3

Follow the guidelines

Section 4.3

Intervening CONCLUSION

Undertake the project work

Conclusion

Carry out regular maintenance

Conclusion

${ }^{39}$ Standards and Guidelines for the Conservation of Historic Places in Canada, 3. 


\section{DESIGNATION AS A NATIONAL HISTORIC SITE}

To receive designation as a National Historic Site, the person, place, or event must have had a nationally significant impact, or demonstrate a nationally important aspect of Canadian history. ${ }^{40}$ In 1997, the Central Experimental Farm was designated a National Historic Site of Canada, and the entire 427 hectares (1055 acres) (FIGURE 6) of the site are included in the designation. The heritage value of the place lies in the composition of its natural, built, and landscaped elements which together define its character as a distinct cultural landscape. As stated in the Statement of Significance the three most important contributors to Farm's heritage value are ${ }^{41}$.

1. The picturesque composition of its various programmatic elements which reflect the $19^{\text {th }}$ century philosophy of agriculture.

11. The significant contribution to agriculture in Canada since its establishment.

1II. The symbolical representation of the central role agriculture has played in shaping the country as well as its central position in the city.

Designation as a National Historic Site is merely "honorific." A plaque designating its historic significance is located at the corner of the National Capital Commission Scenic Driveway and Maple Drive (FIGURE 7). Unlike provincial designation, federal designation as a historic site does not provide protection against changes or development to the place, proving increasingly problematic for the Farm in the face of urban development pressures. The Central Experimental Farm National Historic Site Management Plan, as mentioned in the Introduction, is a long-term framework based on a cultural landscape approach to land management. The plan focuses on understanding the place in its entirety before making recommendations about its parts.
CHARACTER DEFINING ELEMENT

SPATIAL ORGANIZATION

Picturesque nature of the site

\footnotetext{
${ }^{40}$ Parks Canada Agency, Government of Canada. "Parks Canada - Historic Sites and Monuments Board of Canada - The Evaluation Criteria of the National Commemoration Program." Parks Canada -

Historic Sites and Monuments Board of Canada - The Evaluation Criteria of the National

Commemoration Program. January 10, 2011, accessed November 10, 2016 http://www.pc.gc.ca/clmhc-hsmbc/ncp-pcn/evaluation.aspx.

${ }^{41}$ HistoricPlaces.ca - HistoricPlaces.ca, accessed January 02, 2017, http://www.historicplaces.ca/en/repreg/place-lieu. .aspx?id=13811.
} 


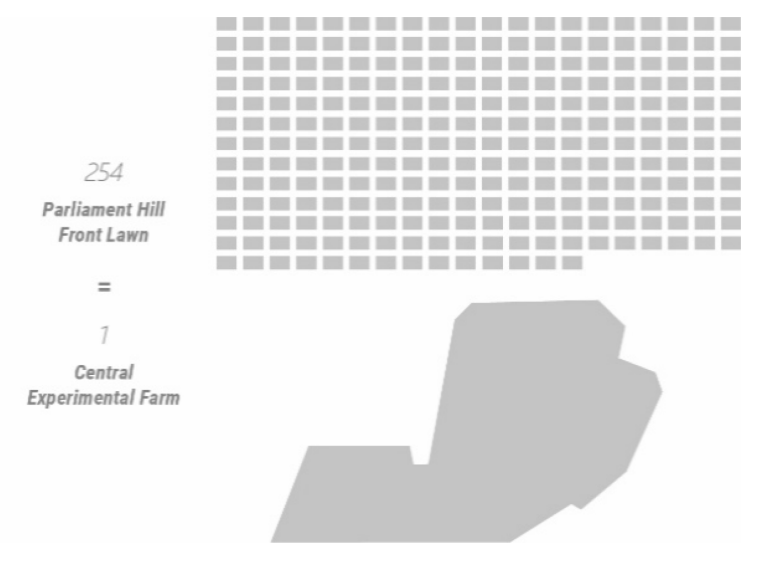

| FIGURE 6

The Farm compared to the Front Lawn of Parliament Hill.

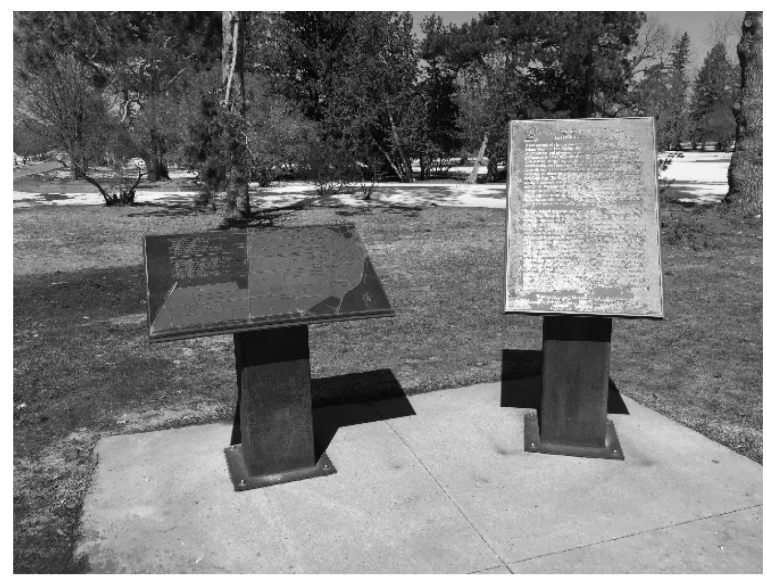

FIGURE 7

National Historic Site plaque located at the corner of the central lawn (Little, 2017). 


\section{Part Two}

NATIONAL CONTEXT

2.1 The Dominion Experimental Farm System

2.2 Research at the Central Experimental Farm

2.3 Agricultural Landscapes of Canada

2.4 Memory of the Agricultural Landscape 


\subsection{The Dominion Experimental Farm System}

The Central Experimental Farm was one of five experimental farm stations established across Canada in the late $19^{\text {th }}$ century to advance agricultural production in the young nation. ${ }^{42}$ The establishment of these farms was the fourth attempt to establish experimental research facilities in Canada after abandoned attempts in 1821, 1831, and 1838 (FIGURE 1). In 1884 a committee was formed by the House of Commons to investigate how to improve agricultural production across the country. The committee concluded that an experimental farm which would test foreign grain, trees, fertilisers, and plant seeds across the territory of the Dominion was the solution. ${ }^{43}$ After further studies, legislation passed in 1886 which allowed the establishment of five experimental farms. Professor William Saunders from the University of Western Ontario was appointed the Director of this Experimental Farm Service.

The farms included: The Central Farm in Ottawa for the Québec and Ontario regions; Nappan, Nova Scotia for the Maritime provinces; Brandon, Manitoba for the central area; Indian Head, NWT for the Prairies; and Agassiz, British Columbia for the West Coast. These new experimental farms were to test crops and fertilisers, livestock housing, nutrition and management of animals, as well as promote the planting of shelterbelts around the perimeters, and various species of trees, shrubs, perennials, and flowers at all farm locations. ${ }^{44}$ The original five sites have since expanded to include a nationwide network of stations, substations, and field sites. ${ }^{45}$ The network of farms have contributed to research and development of the Canadian agricultural industry, particularly in adapting grain varieties to Canadian soil and climate. Characteristic of this time in scientific research was the use of chemistry and genetics to improve upon plants species. Of the five experimental farms, the Central Experimental Farm was designed to be the headquarters of the network of Experimental Farms and a national and international showpiece of Canada's agricultural ambition due to the proximity to the seat of government. See MAP 1 denoting the nationwide network of experimental research stations.

\footnotetext{
${ }^{42}$ Central Experimental Farm Integrated Services; Agriculture and Agri-Food Canada; Government of Canada "About the Central Experimental Farm," Central Experimental Farm Integrated Services; Agriculture and Agri-Food Canada; Government of Canada, December 23, 2015, accessed December 2, 2016, http://agr.gc.ca/eng/about-us/offices-and-locations/central-experimentalfarm/about-the-central-experimental-farm/?id=1169564397864.

${ }^{43}$ Stephen Morgan Jones, "Agricultural Research Stations," The Canadian Encyclopedia, accessed December 2

${ }^{44} \mathrm{Ibid}$. 2016, http://www.thecanadianencyclopedia.ca/en/article/agricultural-research-stations/.

${ }^{45}$ Central Experimental Farm Integrated Services, accessed December 2, 2016, http://agr.gc.ca/eng/aboutus/offices-and-locations/central-experimental-farm/about-the-central-experimentalfarm/?id=1169564397864.
}

\section{CHARACTER DEFINING ELEMIEN}

LAND PATTERNS

Location in the urban centre of Ottawa 


\section{AN URBAN FARM}

As seen in MAP 2, the conditions surrounding the Farm are unique from the other four experimental farms established at the same time. The other four farms have remained surrounded by rural fabric, making them less distinguishable from their surroundings. The Farm has gradually become surrounded by urban fabric on all sides, making the threshold between farm and city more immediate. The urban conditions of the Farm also make the land highly vulnerable to the encroachment of the development and often degrading environmental conditions of the city. Developers see the Farm as prime real estate for the development of open space; rare in the core of Ottawa. Maintaining open spaces as Ottawa continues to densify is "critical for the health and benefit if the full spectrum of residents and visitors." ${ }^{46}$ The Farm works to clean our city air while offering a place to relax and take a break from city life with its open spaces and impressive views.

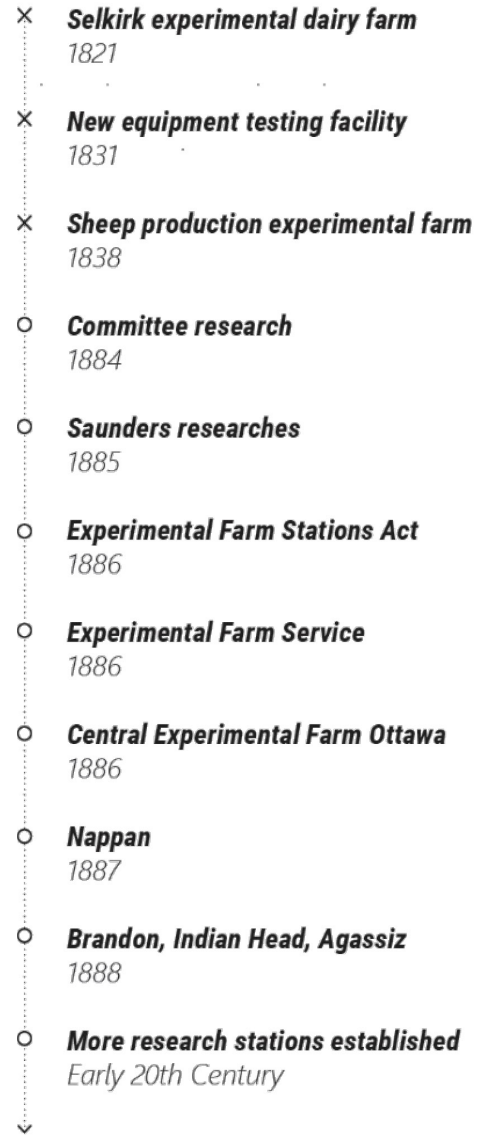

${ }^{46}$ Jones, Eric. "Friends of the Farm Presidents Warn of Development Creep." Friends of the Central Experimental Farm (Ottawa), November 13, 2014 


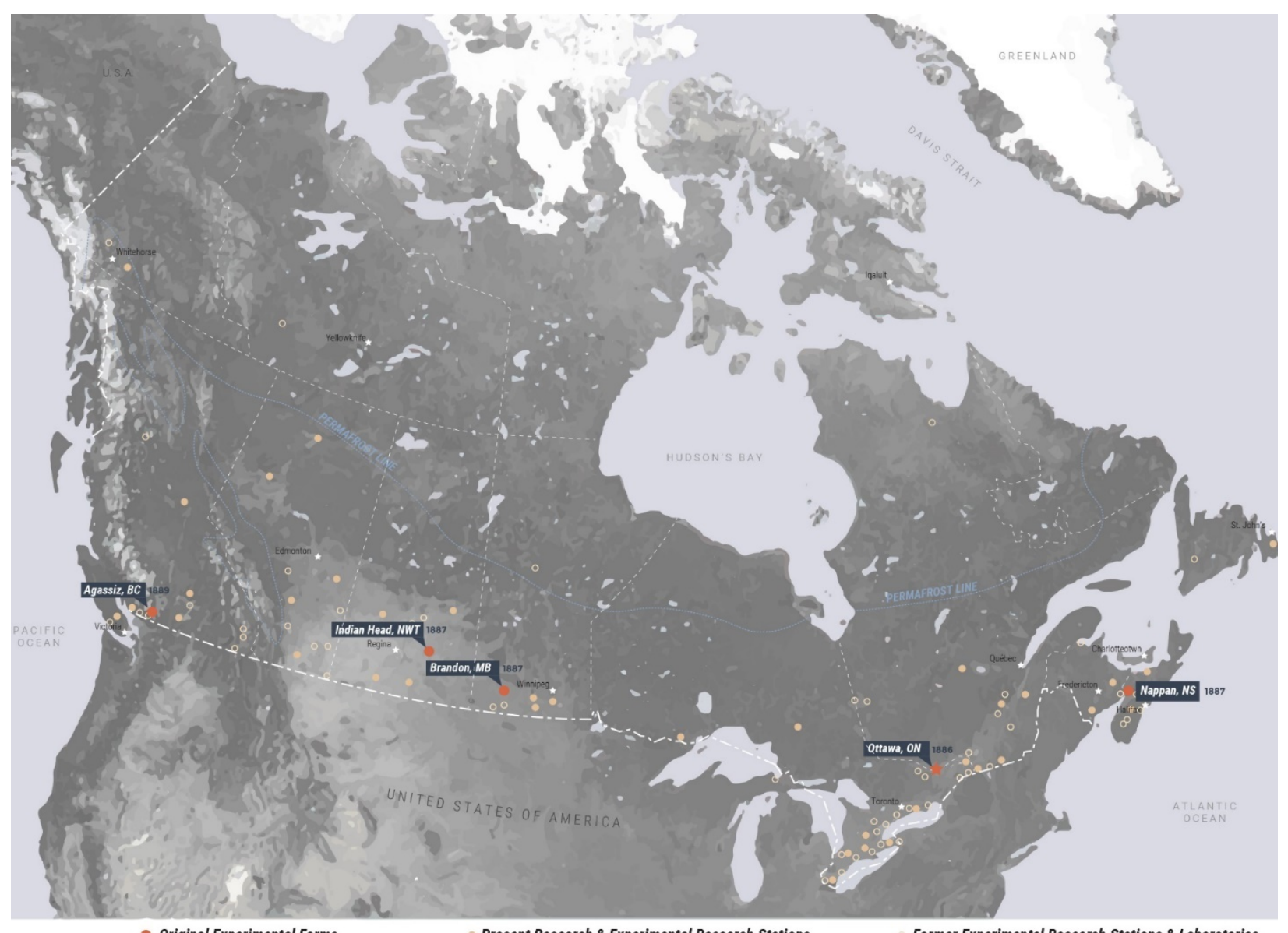

MAP 1

Experimental farms, stations, and laboratories of the Research Branch of Agriculture Canada across the nation. 

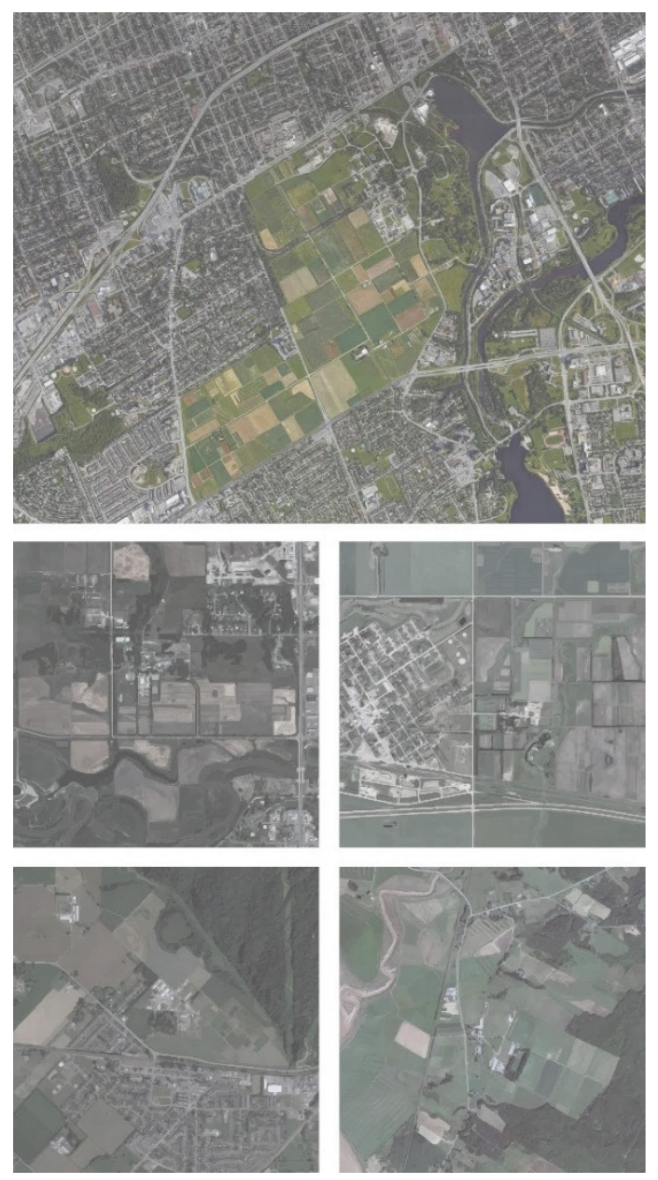

MAP 2

The original five experimental farms shown at same scale as they exist today. Clockwise from top: Central Experimental Farm, Indian Head Research Station, Nappan Research Station, Agassiz Research Station, and Brandon Research Station. 


\subsection{Research at the Farm}

The Farm has formed the building blocks on which the Canadian agricultural industry has depended for over a century. The farmland which makes up the Farm is foremost a research laboratory. The 427-hectare urban property is home to the Ottawa Research and Development Centre, the research branch of the Department of Agriculture and Agri-food, and includes research fields, laboratories, offices, barns, outbuildings, greenhouses, gardens, scientific collections, research records, and workforce which fuels the scientific focus of the Farm. The research of the Farm does not instantly solve agricultural problems, but over time continuously contributes to improving rural farming practices. ${ }^{47}$

\section{AGRICULTURE AND AGRI-FOOD INDUSTRY}

At the heart of this massive industry lies the knowledge, research, and innovation of the federally managed Department of Agriculture and Agri-food (Agriculture and Agri-food Canada/AAFC). The AAFC is responsible for the policies governing agriculture and agri-food production, farming income, inspection, regulating of animals and plants, and research and development. ${ }^{48}$ From its beginning, AAFC's research has been vital to Canada's rich agricultural system. AAFC's research has provided agricultural expertise to farmers for over 130 years, equipping farmers with the knowledge to effectively manage their plant and animal crops. Research includes fighting disease, improving crop varieties and yields, sustainable practices, and ensuring the healthy, safety, and quality of the products. ${ }^{49}$

From feeding us to employing us, Canada's agriculture and agri-food sector are greatly interwoven into the lives of all Canadians. Canada is the fifth largest agricultural exporter in the world and leads the production and exportation of flax seed, canola, pulses and durum wheat. The agriculture and agri-food industry employs 2.1 million Canadians, making up 1 in every 8 jobs, and contributes $\$ 100$ billion annually to Canada's gross domestic product (GDP). ${ }^{50}$ The scope of the agriculture and agri-food sector goes beyond the farm. The manufacturing sector also relies heavily on the agriculture and agri-food industry turning harvested crop into usable products. For example, the milling of grain to flour. Besides harvesting food agriculture

The production of crops and animals (NAICS, 111 \& 112).

agri-food

The manufacturing of all food and beverage products (NAICS, 311 \& 312).

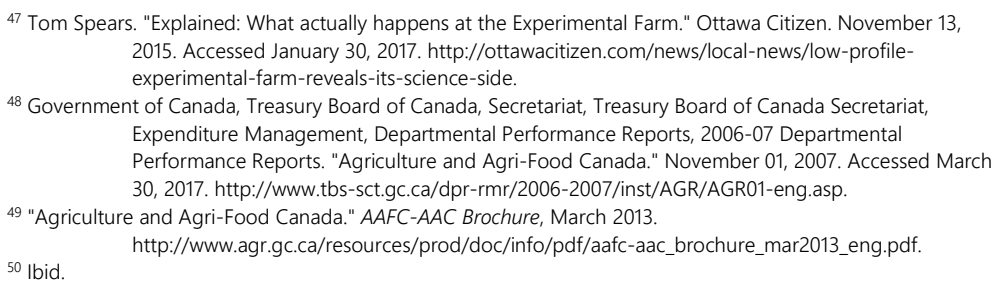


for our consumption, the agricultural sector harvest products which are used in many daily household and healthcare products. As predicted by the "2018 Canadian Agricultural Outlook", the world population is expected to increase by $10 \%$ by 2025 , therefore increasing the global food demand and creating opportunities for the Canadian Agriculture and Agri-food Sector. ${ }^{51}$

What makes this agricultural landscape scientific, or for its namesake; what makes the Farm experimental?

The Farm's scientific identity has been described as "hiding in plain sight." 52 Despite occupying 425 hectares of experimental fields and plots on Farm in the core of Ottawa, $27,000 \mathrm{~m}^{2}$ of laboratory space, and $2,300 \mathrm{~m}^{2}$ of greenhouses (integrated growth facility), the research of the Ottawa Research and Development Centre is not overtly clear. The rows of wheat, corn, and oats are visible while driving down Baseline Road, Fisher Avenue, and just about anywhere along the perimeter of the Farm. The rows of crops are visible as they grown throughout the summer and harvested in the fall, appearing like a pastoral piece of agricultural landscape. The fields are display a variable collection of colour, texture, scales, and seasonal variations.
CHARACTER DEFINING ELEMENT VISUAL RELATIONSHIPS

Views from the periphery

\section{CHARACTER DEFINING ELEMENT}

SPATIAL ORGANIZATION

Pastoral appearance

\section{CHARACTER DEFINING ELEMENT}

LAND PATTERNS

Variable sizes, colours, textures,

seasonal variations of fields

\section{Is the research still relevant?}

The Ottawa Research and Development Centre leads Eastern Canada in crop development with a focus on soy, spring wheat, winter wheat, oats and barley. ${ }^{53}$ The Centre's main areas of research focus on:

- Crop genetic enhancement and genomics

- Biodiversity of vascular plant, fungi and bacteria, and invertebrates

- Integrated assessment of long-term environmental effect of agricultural practices ${ }^{54}$

Experiments carried out at the Farm include: improving crops' resistance to drought, invasive worms and insect studies, and improving soil conditions. ${ }^{55}$ The crop map in MAP 3 shows the variety of experiments carried out in 2013 from barley, canola, corn, oats, spring and winter wheat, sunflower research. The map also includes crop plots for hay and pasture.

\footnotetext{
${ }^{51}$ Agriculture and Agri-Food Canada; Government of Canada. "2017 Canadian Agricultural Outlook." Agriculture and Agri-Food Canada; Government of Canada. February 17, 2017. Accessed February 20, 2017. http://www.agr.gc.ca/eng/about-us/publications/economic-publications/2017-canadian- 


\section{Could the Farm be moved to another location?}

Due to the prime location of the Farm, developers argue that the Farm could be moved to another location outside the city. It is possible to move the Farm; however, it would be a major project. Much of the climatic history of the site would be lost and in the coming years, this information will become more vital than ever before. The new growing conditions arriving with climate change will make for longer seasons, higher temperatures, and an increased frequency of drought. These conditions are most effectively tested outdoors on land with existing historical data. Developing a piece of the research plots is analogous to "tearing down a research laboratory," as stated by the Associate Dean of the Ontario Agricultural College, Rene Van Acker. There is over a century of data accumulated on this farmland. Research which continually contributes to the research of the Ottawa Research and Development Centre's body of work. Some research plots have been continuously monitored since the Farm's establishment in 1886. The site was also chosen for its unique variety of soils (MAP 4) and climatic conditions which mimic that of Ontario and Quebec as well as for the proximity to the seat of government - both physically and symbolically.

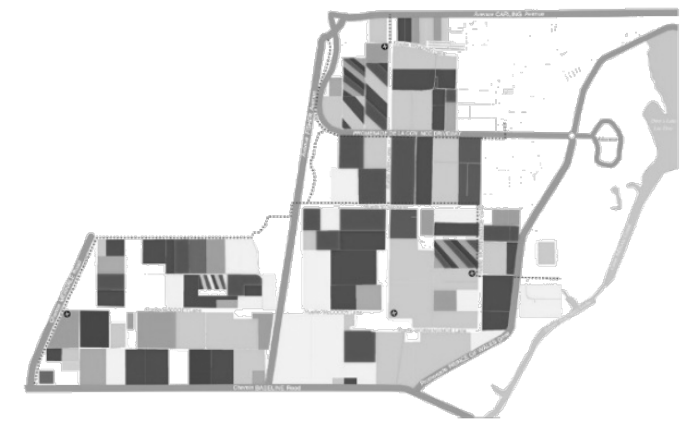

\section{MAP 3}

A crop map of the Farm from 2013. Crops include Yellow indicates corn research; dark green indicates soybean research; and the different shades of pink indicate spring and winter wheat (Agriculture and Agri-food Canada).

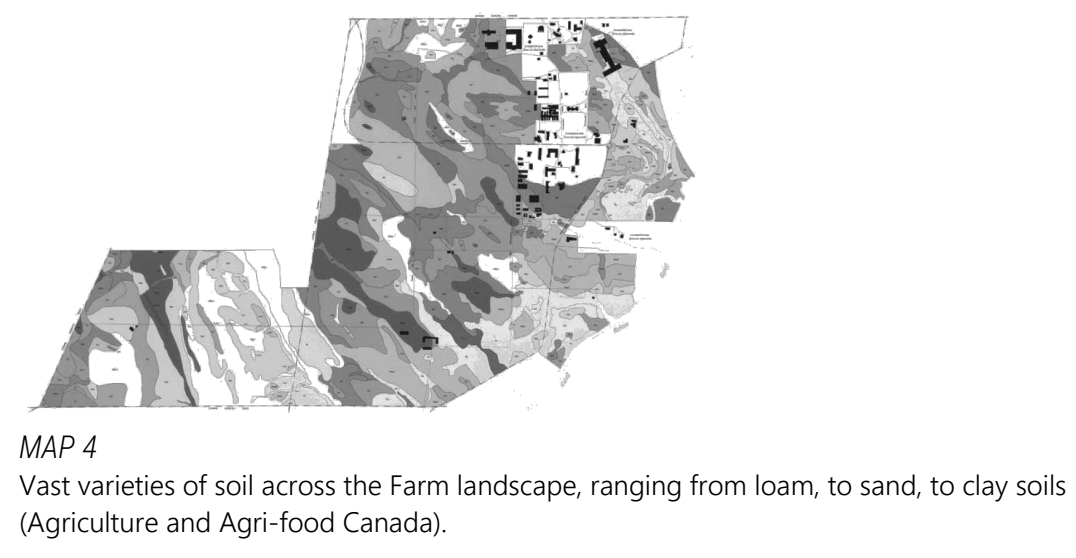

CHARACTER DEFINING ELEMIENT

EVIDENCE OF LAND USE Variety of soil types, cleared fields, and various buildings 
Can the research be done indoors?

As stated by the Associate Dean of the Ontario Agricultural College, Rene Van Acker, "agriculture happens outside." Although there are growth rooms and facilities, and greenhouses located on the property, it is difficult to duplicate the precise factors which influence the growth of the plants in the field. The temperature fluctuations, rainfall, early frost, and late frost cannot be duplicated in a greenhouse or growth chamber. The initial selection of crops is tested at the Farm and then tested at six other sites throughout eastern Canada for yield and quality, making it difficult to duplicate all the diverse climate regions of Canada indoors.

\section{What about sections of the Farm where research does not take place?}

Recently, areas of the Farm which are not used primarily for research have been targeted for redevelopment. They include the area southwest of Fletcher Wildlife Gardens for the National Botanical Garden (Canadensis: The Garden of (anada) and the site of the demolished Sir John Carling Building, vacant since 2014, for the new Civic Hospital. These sites are currently ancillary to the primary research function of the Farm. The National Botanical Garden is less of a threat than the proposed Civic Hospital expansion on to the Sir John Carling site, as a botanical garden was a part of the original vision of the Farm, and could compliment the "horticultural node" which includes the Arbouretum, the Fletcher Wildlife Garden and the ornamental gardens. ${ }^{56}$ Allowing these types of developments onto the site sets a precedent for other non-agricultural research development. As indicated in the Management Plan, the vision for an agricultural science identity is vital for the longevity of the Farm, therefore allowing other institutional or commercial endeavours which could be detrimental to the agricultural research campus identity. Another uncertainty which these types of development bring is the unclear boundaries which these developments propose. Per Heritage Ottawa's Leslie Maitland, the limits of the 50-acre Civic Hospital site have changed compared to the map used by the National Capital Commission when looking at possible sites for the hospital expansion last year. ${ }^{57}$ This thesis recognises the importance of health care developments in the city. The ancillary spaces which come along with these types of developments, including parking, propose environmental uncertainty as the urban border will be pushed further into the site. However, another serviced, uncontaminated, and a historically less significant site

\footnotetext{
${ }^{56}$ Laucius, Joanne. "Planting the seed: Group aims to break ground for national botanical garden in 2017." Ottawa Citizen, June 16, 2016. http://ottawacitizen.com/news/local-news/planting-theseed-group-aims-to-break-ground-for-national-botanical-garden-in-2017.

${ }^{57}$ Elizabeth Payne, "Cleanup costs for new Sir John Carling hospital site in the millions." Ottawa Sun, accessed March 23, 2017. http://www.ottawasun.com/2017/03/22/cleanup-costs-for-new-sir-john-carling hospital-site-in-the-millions.
}

CHARACTER DEFINING ELEMENT

BUILT FEATURES

Glass and metal greenhouse frames

CHARACTER DEFINING ELEMENT

BUILT FEATURES

Buildings named after key

figures in Canadian agriculture

\section{FORCES}

ECONOMIC

Urban development which lacks alignment

with scientific research ambitions

\section{FORCES}

SOCIO-CULTURAL

Lack of appropriate development of

vacant Sir John Carling site 
would be more appropriate. Other areas of the Farm in which development has been proposed include the lands south of Carling Avenue including the historic Plot \#1. The land adjacent to Baseline Road a rapid transitway proposes to impede approximately seven metres into the Farm contributing to the gradual "erosion" of the Farm's physical space and intangible legacy.58 The research plots on Carling Avenue and Baseline Road are already facing degradation due to salt contamination on these edges. Pushing the edges of the Farm in further without proper shelterbelt protection will only increase the salt damages to these active research plots. Once the open space of the Farm is developed, it is unlikely it could ever be restored.

The Dominion Arbouretum is also an area of the Farm where active research does not take place, however it is considered an important part of Ottawa's park network, and developers would not consider proposing development. It is estimated 175,000 visitors come to the Arbouretum each year to enjoy the result of the oldest plant hardiness research programs in the country - some plants and shrubs planted in 1889 - and wander around its Picturesque pathways. The Dominion Arbouretum is a recognised link in the Capital's green urban space network. ${ }^{59}$ Unlike the Research Fields, it is protected from wind and sun, provides a pedestrian scale scenic walk, and has several comfortable resting spots.

\section{FORCES}

ECONOMIC

Rapid Transitway development

on Baseline Road and Carling Avenue

\section{FORCES}

NATURAL

Salt contamination to research plots adjacent to Baseline

Road and Carling Avenue

\section{CHARACTER DEFINING ELEMENT}

\section{CIRCULATION}

Paths in the Arbouretum

\section{CHARACTER DEFINING ELEMENI}

VEGETATION

Arbouretum's wide variety of specimen trees and shrubs

\section{FORCES}

TECHNICAL

Lack of pedestrian rest

spots in the Research Fields

\footnotetext{
${ }^{58}$ Waubgeshig Rice, "Strip of Central Experimental Farm could be lost to Baseline rapid transit corridor." CBC News. February 01, 2017, accessed February 04, 2017.

http://www.cbc.ca/news/canada/ottawa/baseline-rapid-transit-experimental-farm-expropriation1.3960257 .

59 Plan for Canada's Capital, 2017-2067: Public Consultation Report Summer 2016. Ottawa: CNN / NCC, 2016, accessed February 04, 2017. http://www.ncc-ccn.gc.ca/sites/default/files/pubs/08.1_2017-p68e__appendix_3_-_pfcc_public_consultation_report.pdf, 38.
} 


\subsection{Agricultural Landscapes of Canada}

\section{THE FIRST MANAGED LANDSCAPE}

Agriculture had been practised in North America long before the arrival of Europeans. Beyond gathering plants, and hunting animals First Nations "cared for, nurtured, and controlled wild plants and animals" diligently for centuries to yield sufficient quantities. ${ }^{60}$ The Ojibways and Anishinabe weeded and reseeded wild rice marshes annually. In the Maritime provinces, the Mi'kmaq created sophisticated pond and weir systems, and the Haida of the West Coast built rock walls and used an intricate system of nets to catch fish moving with the tides. ${ }^{61}$ Beyond the gathering of wild plants, some First Nations intensively practised agriculture. The Iroquoian peoples of the St. Lawrence Valley and the Great Lakes region and the Algonquians - including the Mi'kmaqs, Maliseets, and Abenakis also cultivated crops based on methods developed in Mexico over 3,000 years ago. ${ }^{62}$ The cultivation of two types of corn, winter squashes, and beans "The Three Sisters" - was a staple to these peoples. These crops were often sowed together in alternating rows to take advantage of their complementary qualities. ${ }^{63}$ The low-lying leaves of squash suppressed weeds and retained moisture in the soil, while the cornstalks acted as stakes for the bean vines and helped to return nitrogen from the air to the earth. ${ }^{64}$ Aboriginal agriculture was also an important part of trading. Agricultural aboriginals traded corn with woodland hunters in exchange for skins and meat. After the arrival of French traders, the Algonquian continued to trade with more northern peoples and subsequently traded those furs with the French until the late $18^{\text {th }}$ century. First Nations were the first managers of the agricultural landscape in North America and practised this management with sensitivity and sustainability. A strategy the European colonisers of "Canada" would not employ in their methods for decades. Approximately half of the global food crops, including peppers, peanuts, potatoes, and vanilla, were grown in North and South America long before the arrival of the first Europeans. $^{65}$

Harvesting food from the landscape differed greatly in the approaches of the First Nations and the first European colonisers - in both theory and practice. The First Nation's maintained a sacred relationship with Nature and believed that humans were fully a part of Nature, not in opposition to Nature. ${ }^{66}$ This relationship to Nature shared by the First

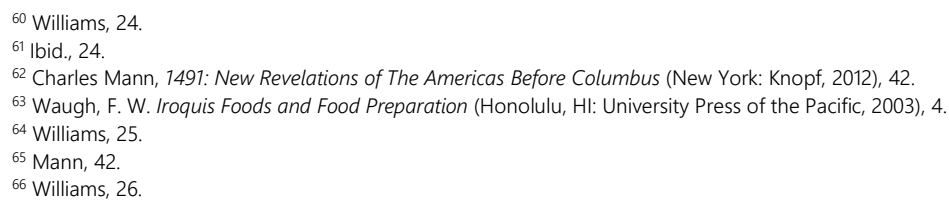

${ }^{62}$ Charles Mann, 1491: New Revelations of The Americas Before Columbus (New York: Knopf, 2012), 42.

63 Waugh, F. W. Iroquis Foods and Food Preparation (Honolulu, HI: University Press of the Pacific, 2003), 4.

${ }^{64}$ Williams, 25

${ }^{65}$ Mann, 42.

${ }^{66}$ Williams, 26 
Nation's, however, should not be exaggerated to suggest Native peoples had no impact on the landscape which they lived. It is a false assumption to believe that the First Nations live in "perfect harmony" with Nature. The scale of which Native peoples cultivated crops extended over "hundred of hectares" yielding significant quantities. ${ }^{67}$ Also, the lack of fertilisers and crop rotation when growing corn depletes the soil of minerals, causing the abandonment of fields and the relocation of communities at least every twelve years. ${ }^{68}$ In addition to deforestation due to the relocation of agricultural communities, the deforestation for hunting purposes had an impact on the landscape. "Controlled fires" set by the First Nation's attracted wild game to the improved grazing conditions after the burning of the underbrush and the subsequent regrowth of plants. ${ }^{69} \mathrm{~A}$ generation after the first colonists arrived, new growth began to show in these controlled burn areas, after Native populations diminished in areas.

Although the First Nations had a visible impact on the land, the scale at which Europeans transformed the landscape is unprecedented. The first generation of European farms in Ontario was far from the rural landscape as it is seen today throughout the province. The rural landscape of the nineteenth century was defined by mass land clearing with little regard for an environmental approach to sustainable land clearing and the impacts on the landscape were colossal - both aesthetically and environmentally. In Ron William's book Landscape Architecture in Canada, he describes the transformation of the rural agricultural landscape by European colonisers specifically in Ontario in three distinct stages. Throughout the new Dominion, colonisers developed the landscape for agriculture with specific vernaculars. For example, the seigneuries system in New France resulted in long strips of agricultural plots that located along a body of water. ${ }^{70}$

\section{THE FIRST EUROPEAN LANDSCAPE $1780^{\prime}$ ' TO 1830'S}

Small clearings in the primitive forest characterised the first stage where a farmer set up a homestead. ${ }^{71}$ Location of these clearings was chosen for their proximity to an existing road - often created by First Nations - and an abundance of fertile soil. To select a fertile area to clear farmers looked at the characteristics of the forest vegetation for an indication of soil quality. ${ }^{72}$ The clearing of the chosen area began by cutting and burning the underbrush, unfortunately often starting forest fires in the process. The trees were then cut down and were used to build simple log cabins. The remaining
MEMORY

LOCAL, REGIONAL, AND NATIONAL

Controlled burns resulting in

grazing meadows to attract animals

\section{MEMORY}

REGIONAL

The seigneurial system in New France

\section{MEMORY}

LOCAL, REGIONAL

Existing passages through forests created by First Nations were used by colonisers to set up first homestead

subsistence agriculture

The practice of growing crops and raising livestock sufficient only for one's own use, without any surplus for trade (Oxford English Dictionaries)

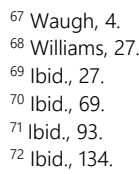


stumps decomposed in place before being removed. ${ }^{73}$ These early pioneers were subsistent farmers, keeping animals and harvesting the land to feed only themselves and their families. ${ }^{74}$ Primitive roads joined these first farm clearings and were often difficult to navigate depending on the season. The frozen winter months often proved easier than the muddy summer months. ${ }^{75}$ As seen in FIGURE 2, an area of primitive forest was cleared for a small farm as indicated by the remaining tree stumps and simple log cabin assembled from tree trunks. The first farm clearing reads as a homestead surrounded by wilderness.

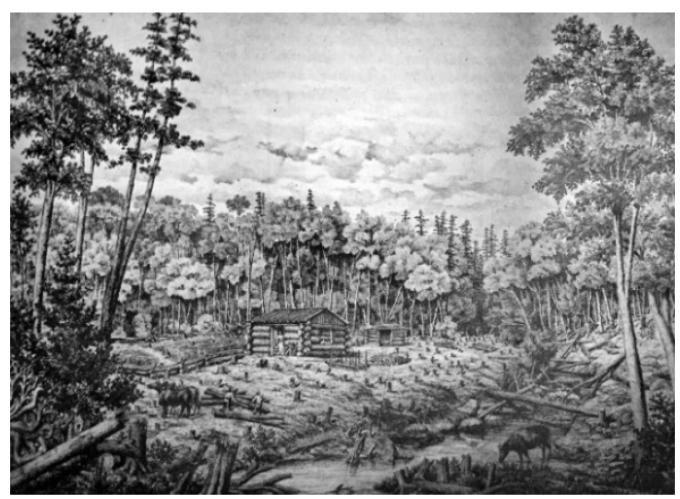

FIGURE 2

An artist's rendering of a first-generation farm - the clearing in the bush (Library and Archives Canada).

\section{THE SECOND EUROPEAN LANDSCAPE 1830'S TO 1860'S}

The second stage expanded the initial small homestead clearings to large open fields of 16 hectares (40 acres) or more. ${ }^{76}$ This mass and rapid deforestation of the landscape was economically driven, opening up the land to farming and yielding wood for fuel and construction. ${ }^{77}$ Economically driven, but technologically enabled, new railways allowed for the transportation of crops to ports for transport to the European markets. ${ }^{78}$ Prosperity in the European markets allowed farmers to replace the log cabins of the first generation farmers to more intricate wood framed houses and barns. The greatly uneducated expansion of farming over the province came with many unanticipated consequences. Firstly, the monoculture of grain crops, specifically wheat, had a progressively negative impact on the soil. The significant demand for these crops and the lack of crop rotation gradually diminished soil quality. ${ }^{79}$ The soil was also made vulnerable to wind erosion

\section{MEMORY}

LOCAL, REGIONAL, AND NATIONAL A clearing in the forest

monoculture

The cultivation of a single crop in an area (Oxford English Dictionaries).

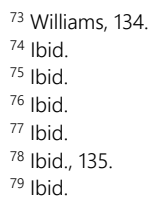


on the newly barren landscape leading to less absorption of spring run-off and subsequent soil erosion and flooding. ${ }^{80}$ The construction of dams enabled navigation through waterways, however greatly disrupted the water levels of lakes and rivers. In some areas, this caused the eradication of native plants. Plants which for centuries had been harvested by First Nations, including wild rice fields. ${ }^{81}$ The open fields prevented snow from settling on fields. Instead was carried across the unprotected fields and provided hostile environments around the homestead. ${ }^{82}$

\section{THE THIRD EUROPEAN LANDSCAPE 1860'S TO 1950'S}

In the third stage, a period of regeneration of the landscape occurred, particularity due to the advanced methods and techniques developed by the network of Experimental Farms across the country. Fields became more sheltered from the prevailing winds by the division of large fields to smaller and more protected allotments and the planting of trees and shrubs also helped to futher shelter these small fields. ${ }^{83}$ Farmers began to cultivate a variety of more specific crops, moving away from the monoculture of grains crops which dominated the previous decades. With greater knowledge of prosperous agricultural practices, including crop rotation and choosing crops adapted to the local soil and climate, farmers could yield exceptional harvests while regenerating the landscape. ${ }^{84}$ The transition from large monoculture plots to smaller market gardening included cash crops like grains, oils, vegetables, tobacco, and potatoes.

\section{MEMORY}

LOCAL, REGIONAL, AND NATIONAL

The planting of shelterbelts

market garden

The relatively small-scale production of fruits, vegetables and flowers as cash crops, frequently sold directly to consumers and restaurants (Oxford English Dictionaries).

${ }^{80}$ Williams, 135
${ }^{81}$ Ibid., 136.
${ }^{2}$ Ibid., 135.
${ }^{83}$ Ibid., 136.
84 Ibid. 


\subsection{Memory of the Agricultural Landscape}

As explored in the previous section, the agricultural landscape, from pre-colonial territory to the present, has changed drastically and has had varying positive and adverse effects on groups of people and their environment. Even in the last seventy years, the agricultural landscape has changed in the eyes of many Canadians. From being the landscape of everyday life to the periphery landscape of our cities, as more and more Canadians urbanise, our identity with the agricultural landscape continues to change. In FIGURE 3, Ottawa's surrounding agricultural landscape shows a landscape which seems very distant to the core of the city and removed from daily lives. Despite the distance from today's urban centres, it is evident that many Canadians have some memory of an agricultural landscape. As shown in MAP 5, the most arable lands in the country are also the most populated, meaning that much of the inhabited land today was first chosen for its potential to cultivate.

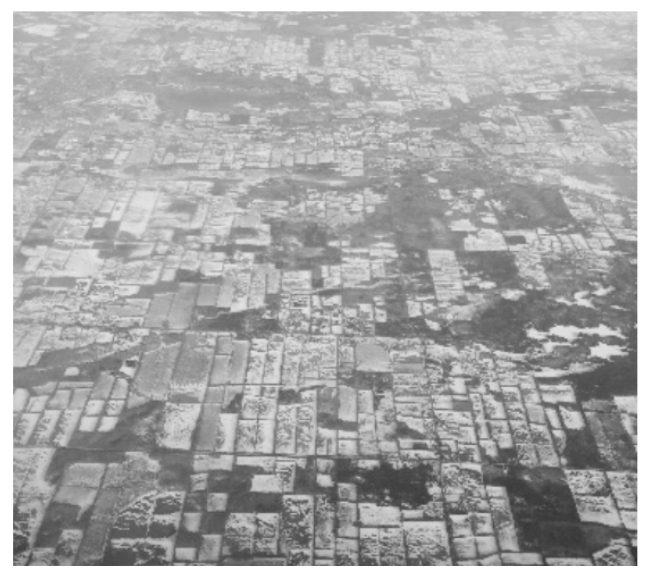

FIGURE 3

Aerial photo of rural Ottawa (Photo: Little, 2017).

What is the shared memory of the agricultural landscape?

There exists a danger when trying to recall the shared memory or define a shared identity of the agricultural landscape - or any landscape for that matter. As Eva Mackey states in her article "Death by Landscape," "identities are formed through definitions of continuity, similarity, and difference. ${ }^{\prime 85}$ Therefore, the formation of a single identity for the agricultural landscape can only be made possible by the inclusion and exclusion of particular groups of people. ${ }^{86}$ This inclusion and exclusion of certain groups arable

Land that can be or is cultivated. (Oxford English Dictionaries).

\footnotetext{
${ }^{85}$ Ewa Mackey, "'Death by Landscape" Race, Mature, and Gender in Canadian National Mythology." Canadian Woman Studies / Les Cahiers De La Femme 20, no. 2 (Summer 2000), 125.
} 
is evident in William Saunders's 1890 description of his transformation of the Farm landscape:

"At the outset the Central Farm was void of all attractiveness save that of its beautiful situation and outlook, but by judicious planning and planting the wilderness has been made to blossom. ${ }^{187}$

The transformation of the landscape into a picturesque landscape is associated with ideas of improvement and prosperity. The picturesque offers the viewer a controlled and manageable view of the landscape, making "the new terrain accessible to colonialists. ${ }^{88}$ However the picturesque view simultaneously makes invisible the landscape of before and the cultures which inhabited it. This viewpoint reinforces the idea that Canada was not inhabited before Europeans and invites colonisers into the landscape. The myth of terra nullius, or "nobody's land" is strengthened by this controlled and improved upon transformation of the wilderness. The picturesque aesthetic is not the only way in which an unoccupied wilderness has been portrayed in Canadian thought. The works of the Group of Seven portray a "impenetrable and uncontrollable" landscape reiterating the idea of a dangerous landscape that is safe for no one, and occupied by no one. ${ }^{89}$

How can we reconcile the memories of past agricultural landscapes in the present time?

Paul Ricœur states that "the necessity of forgetting as a condition for the possibility of remembering." 90 Therefore, memory is a selective process of remembering and forgetting and cultural memory is often defined by the "over remembering" of some things, and the forgetting of others. ${ }^{91}$ This active process of creating memory is not pre-determined, but can be controlled. For something to be remembered it must actively be evoked, using the words of Andreas Huyssen: "it must be articulated to become

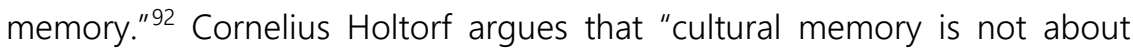
giving testimony of past events, as accurately and truthfully as possible, nor it is about ensuring cultural continuity: it is about making meaningful statements about the past in a given present." ${ }^{\prime 93}$ The complete construction or reconstruction of history is not required for cultural memory, rather

\footnotetext{
${ }^{87}$ Richard Hinchcliff, Blooms: an illustrated history of the ornamental gardens at Ottawa's Central Experimental ${ }^{88}$ Mackey, 127 
investigating "meaningful statements" in the context of today is important. Remembering is an activity of our everyday lives, which helps to give identity to the past and to the present.

\section{REVEALING MEMORY}

As it applies to this thesis, the goal of revealing memory, is not to reconstruct the Farm as it once was, nor continue to reiterate the memories of the Canadian agricultural landscapes which have already dominated our minds. The goal is to make "meaningful statements" about the past, looking beyond the physical and present memories of the site, and into the nationwide and pre-colonial histories of the agricultural landscape. The memories already exist, and it is through the design of the built environment that architects can choose what to articulate.

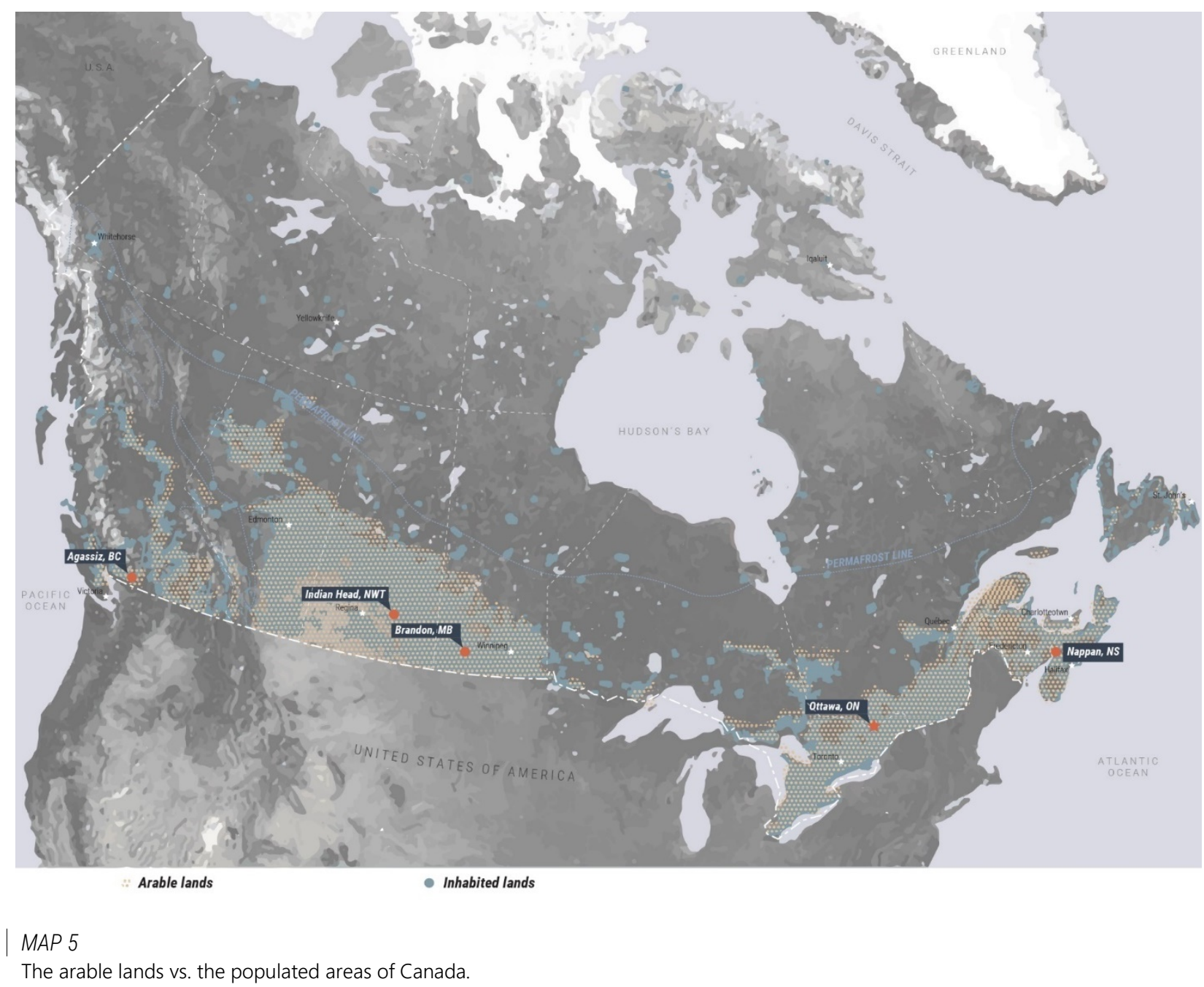




\section{Part Three}

SITE CONTEXT

\subsection{Existing Context}

3.2 History of the Landscape

3.3 Character Defining Elements

3.4 Existing Pedestrian Experience

3.5 Precedent Study 


\subsection{Existing Context}

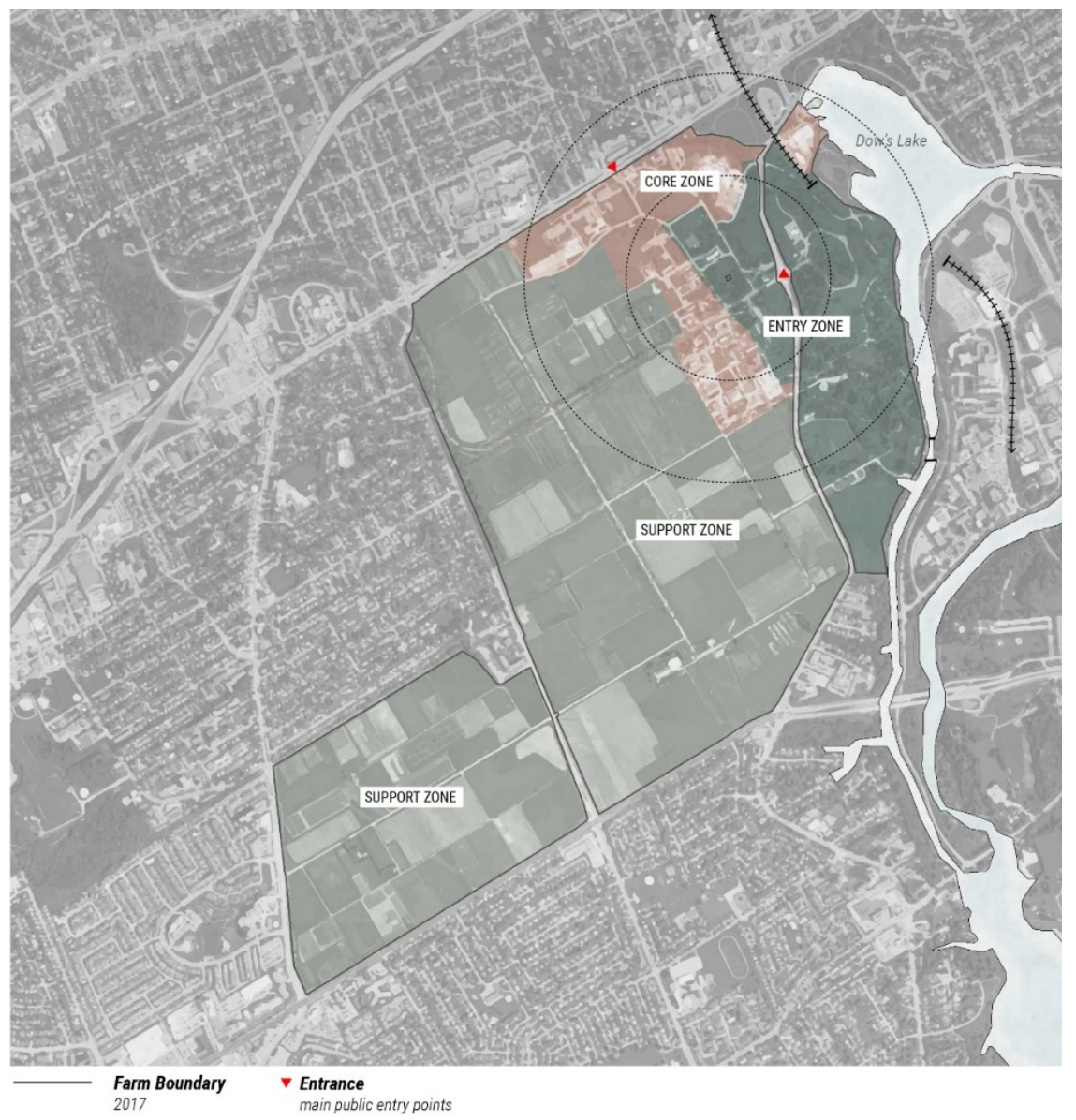

MAP 1 MAJOR LANDSCAPED ZONES

The Farm is divided into three distinct landscape areas: the entry zone, the central core, and the support zone. The entry zone includes the Arbouretum, the Ornamental Gardens, and the Experimental Hedges. The Central Zone includes the administrative, research, and farm buildings and is defined by the intimate, campus-like nature of the planning. The support zone includes the fields, plots, and shelterbelts.

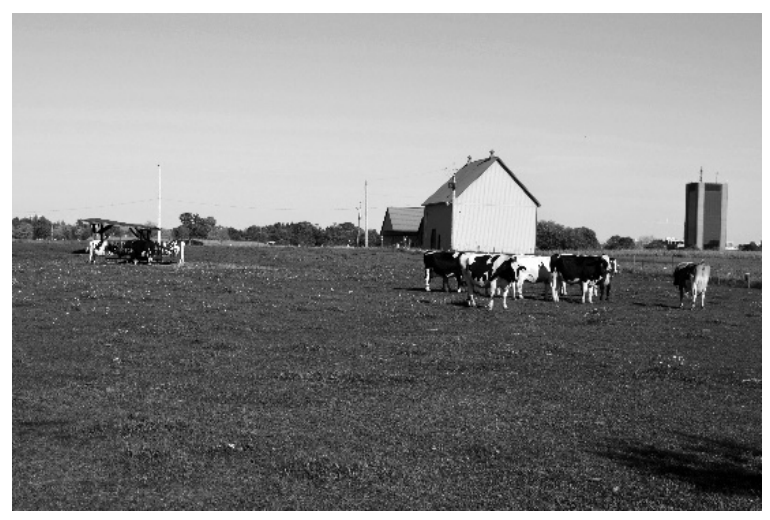

FIGURE 1

Farm structures, pasture, and research fields comprise most of the surface area of the Farm (Photo: Little, 2016).
CHARACTER DEFINING ELEMIENT

SPATIAL ORGANIZATION

Plan made up of three clearly defined zones

\section{CHARACTER DEFINING ELEMENT}

SPATIAL ORGANIZATION

Intimate campus-like

scale of the Central Zone

\section{CHARACTER DEFINING ELEMENT}

BUILT FEATURES

Small, single story board and

batten style support buildings 


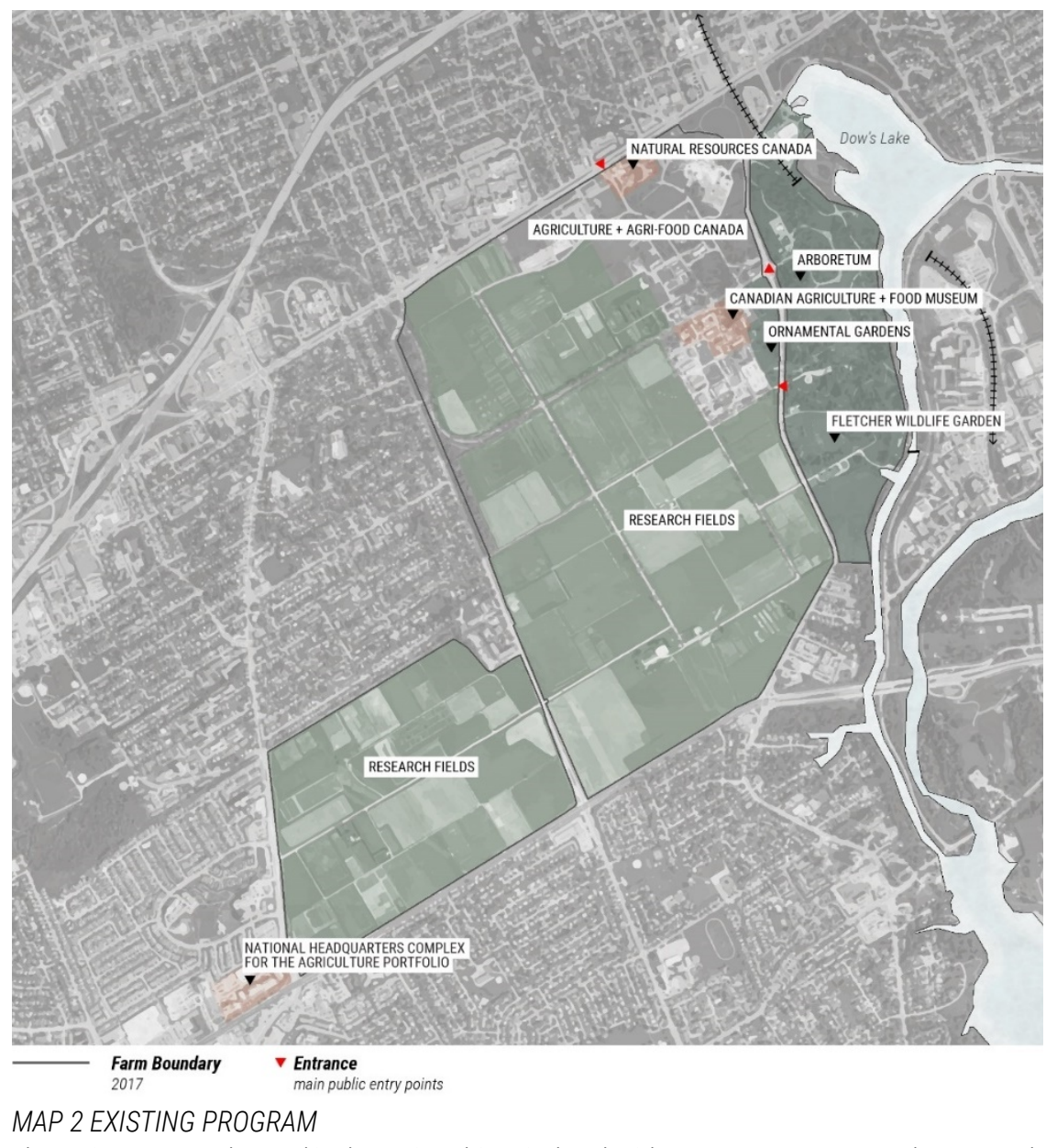

The main programs housed in the various historical and mid-century structures are the Research Branch of Agriculture and Agri-food Canada, Natural Resources Canada, the Canadian Agriculture and Food Museum. The program which occupies the most space by far is the Research Fields, extending to almost all sides of the site. They occupy much of the visual landscape of the Farm and distinctly stand out from the built features of the residential, institutional, and commercial surrounding.

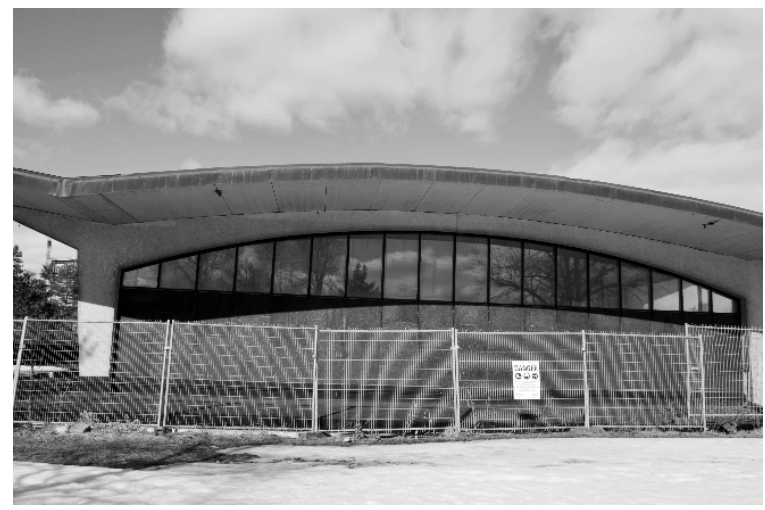

FIGURE 2

The remaining Sir John Carling Building Cafeteria in the Core Zone (Photo: Little, 2017).

\section{FORCES}

\section{ECONOMIC}

Lack of appropriate development for vacant Sir John Carling site

\section{FORCES}

\section{NATURAL}

Contamination of Sir John Carling site

\section{MEMORY \\ LOCAL}

The controversial demolition of the Sir John Carling has left the site contaminated and vacant 


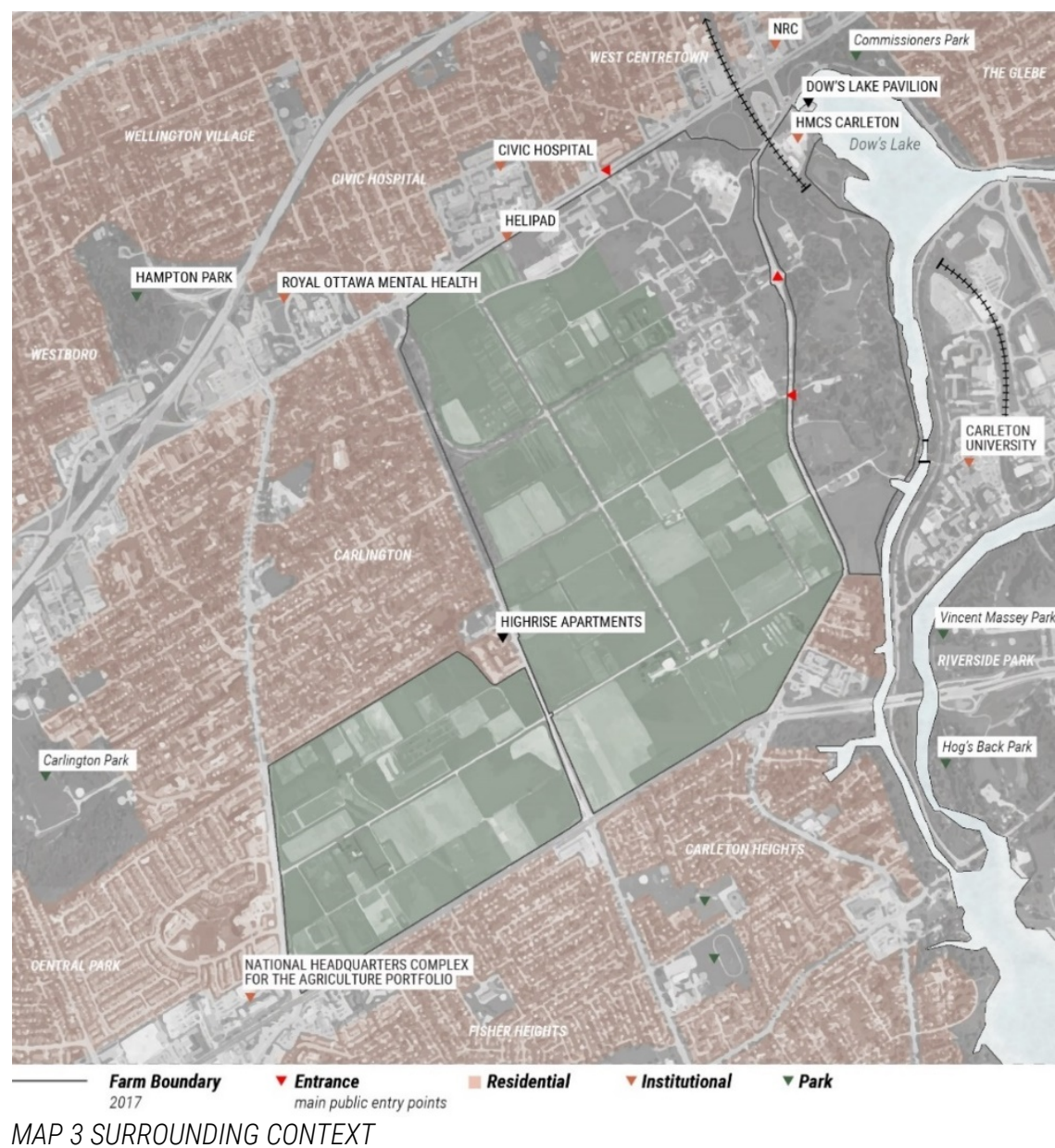

The surrounding context of the Farm is primarily residential, composed of a multitude of lowdensity single-family homes, middle-income townhomes, and high-density housing tower. The secondary program of the surrounding context includes institutional buildings including the Carleton University to the east, the Civic Hospital, HMCS Carleton, and Federal Offices along Carling Ave. There are also a small number of commercial areas, particularly along Baseline Road. Visible from the grounds of the Farm are several high-rise towers including the apartments on Fisher Avenue and Merivale Road, Dunton Tower at Carleton University, and soon to be Clairidge Icon condo tower located at Carling Avenue and Preston Street. The Farm is used by surrounding residents for many pedestrian activities including walking, biking, running, and cross-country skiing in the winter. There is a collection of open spaces within the surrounding neighborhoods. However, the Farm is by far the largest open space in the vicinity.

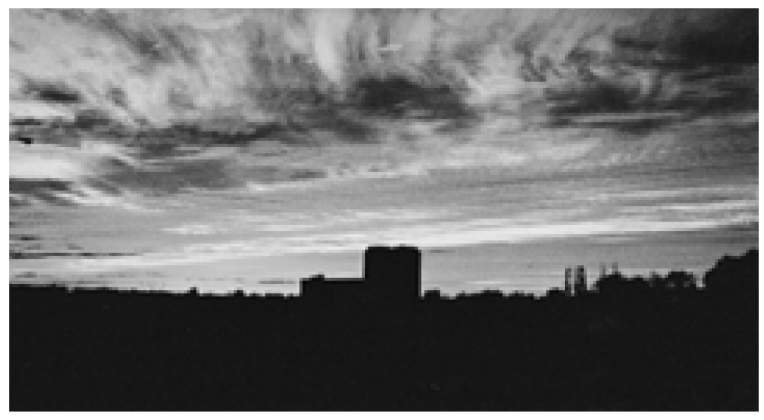

FIGURE 3

Fisher Avenue apartment buildings visible in the skyline of the research fields (Photo: Little, 2012)

\section{CHARACTER DEFINING ELEMENT}

LAND PATTERNS

Location in the urban centre of Ottawa

CHARACTER DEFINING ELEMIENT

VISUAL RELATIONSHIPS

Viewscapes 


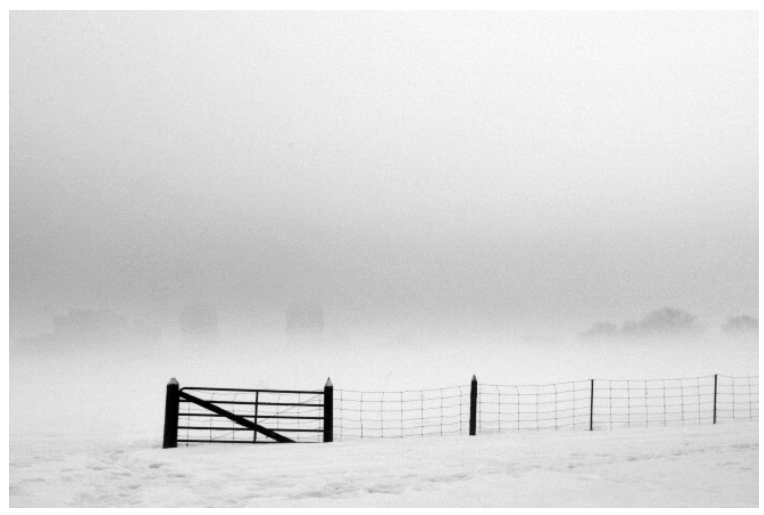

FIGURE 4

From Core Zone looking out to the Support Zone research fields towards Baseline Road. Internal fencing of red "pencil posts" with white tops are representative of the original and economic fencing (Photo: Little, 2017).

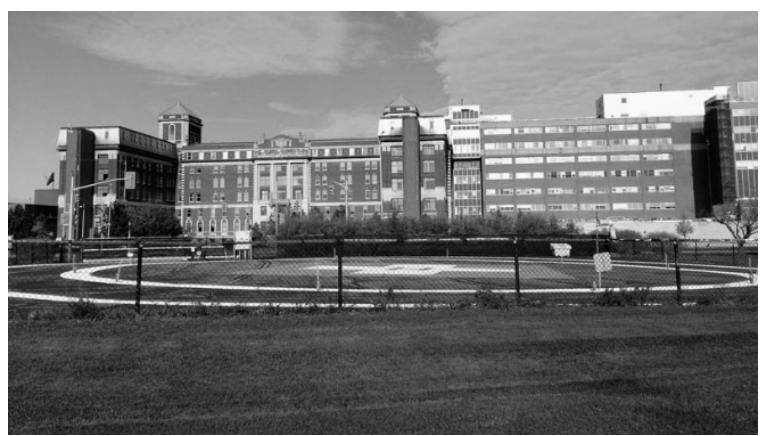

\section{FIGURE 5}

View of Civic Hospital from Helipad on Farm north edge facing Carling Avenue (Photo: CTV News, 2014)

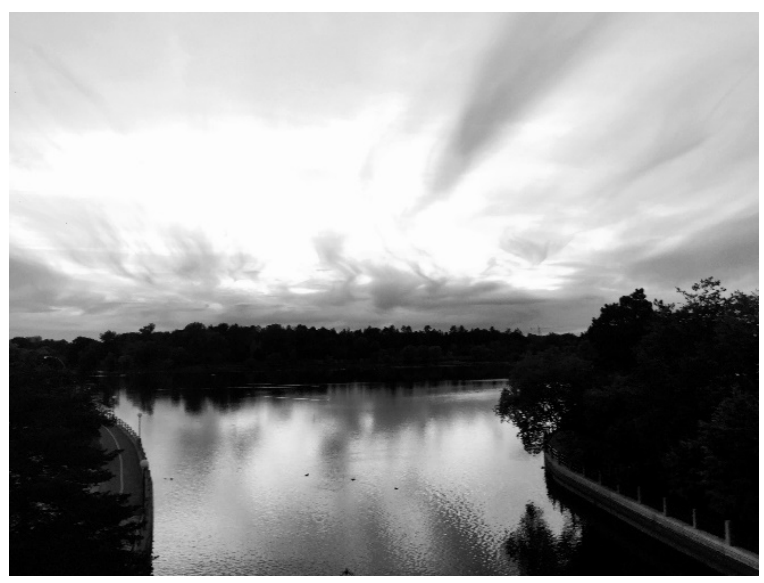

FIGURE 6

Dow's Lake as seen from Bronson Avenue with the Arbouretum in the background (Photo: Little 2016)

\section{BUILT FEATURES}

Internal fencing of red "pencil posts" with white tops 


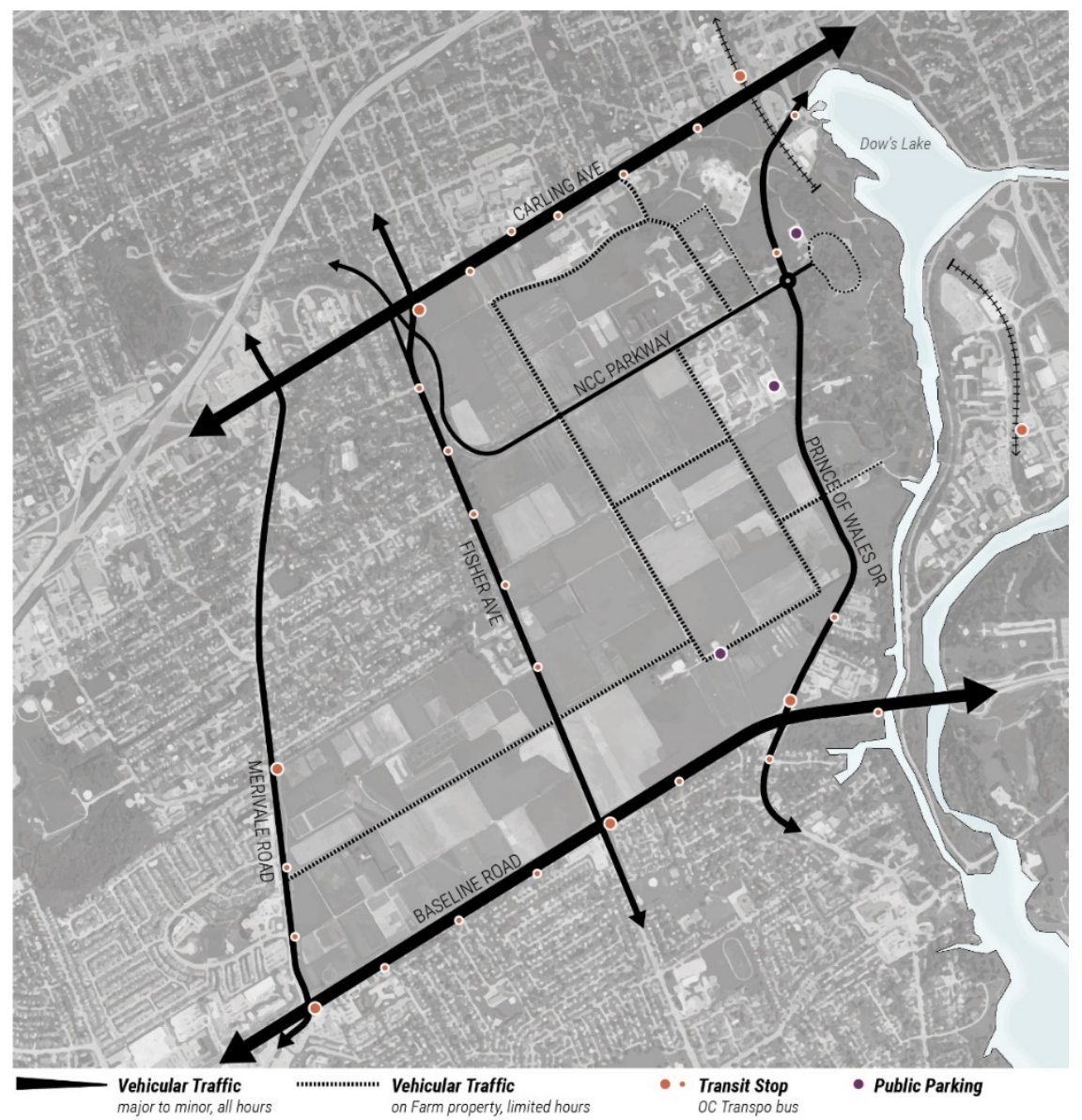

MAP 4 VEHICULAR TRANSPORATION

The major vehicular traffic is on Carling Avenue and Baseline Road. These roads are multilane highways with high numbers of vehicles including public transit. There are several public roads which cut through the site such as the NCC Driveway and Fisher Avenue (FIGURE 7). Other roads which circulate the site include farm roads which are open on a daily and seasonal basis to the public and form the primary transportation route for farm vehicles. Public transportation to the Central Core of the site is poor, consisting of a bus with limited hours and days of service. The lack of public transportation to the centre of the location proves problematic for the visitors and volunteers to the central area, specifically many of the senior population who volunteer at the Friends of the Farm in the Arbouretum. The streetcar line which had a stop at the Farm was removed in the early $20^{\text {th }}$ century.

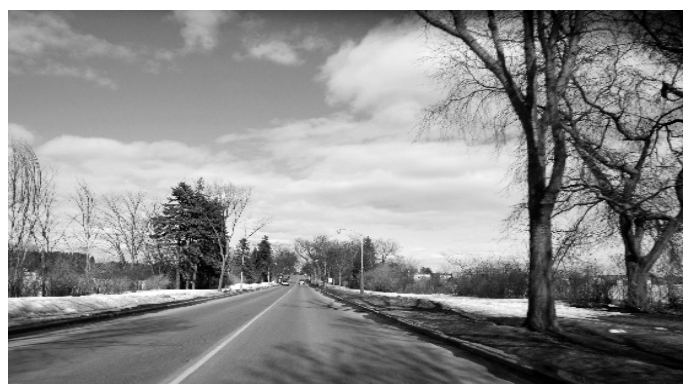

FIGURE 7

The NCC Scenic Driveway was cut through the Farm in the 1930's to reinforce the scenic nature of the site. It is one of three roads which travel through the site, the others include Fisher Ave and Prince of Wales Drive (Photo: Little, 2016)
FORCES

TECHNICAL

Lack of welcoming pedestrian

entry points around perimeter

\section{FORCES}

TECHNICAL

Lack of access to Central Area
CHARACIER DEFINING ELEMENT

\section{CIRCULATION}

Integration of scenic driveways 


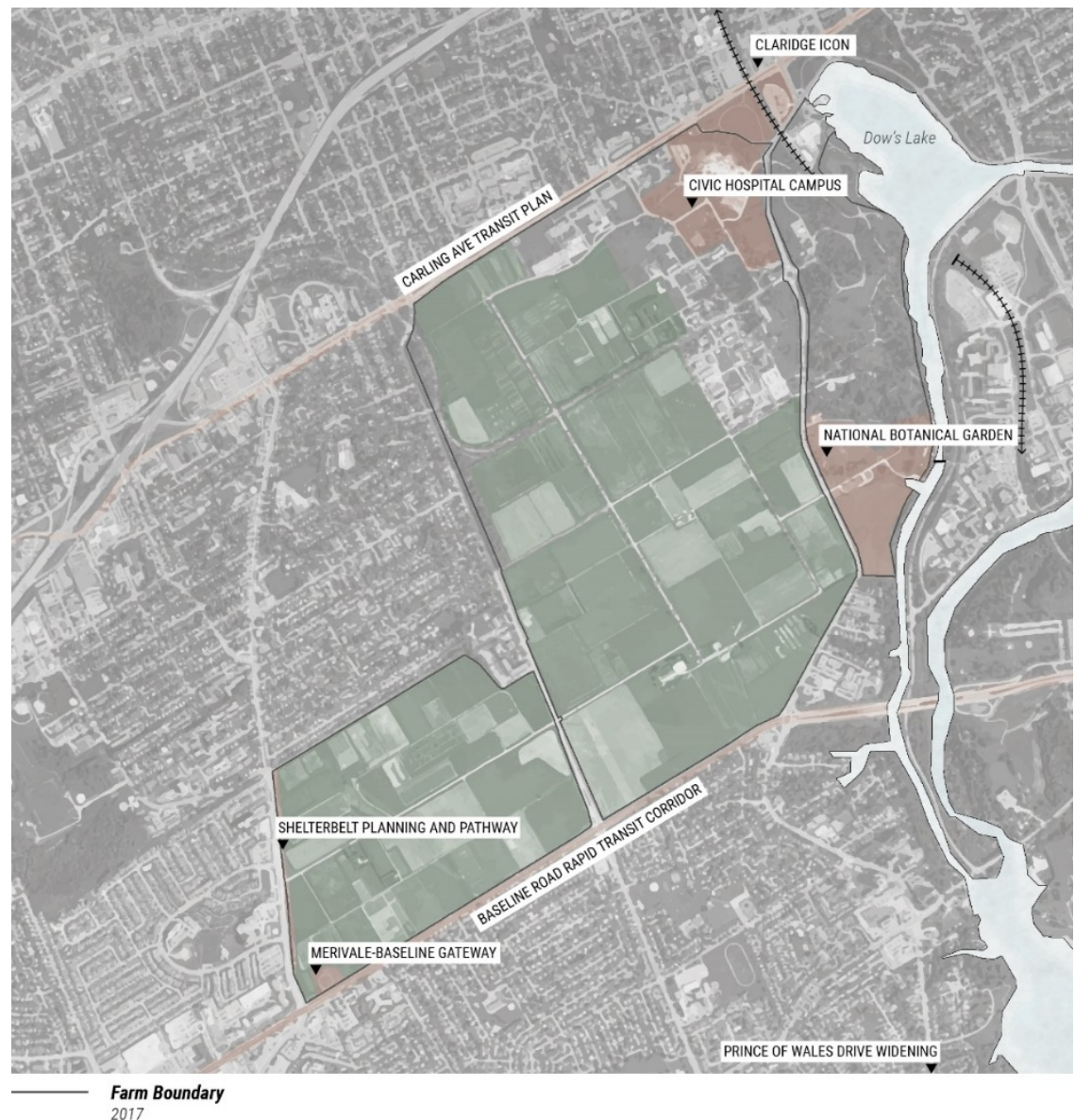

2017

MAP 5 POSSIBLE FUTURE DEVELOPMENT

As indicated in Section 2.2, there is much pressure to develop areas of the site which could be detrimental to the identity and longevity of the Farm. Positive development plans include the Merivale Shelterbelt, which began a few years ago and is slowly growing into a developed planted area on the west side of the Farm. A factor affecting the implementation of the Shelterbelt was due to the lack of water supply to the west portion of the site and the requirement of new plantings to have adequate water supply in their first few years. Also, there are plans to develop the Merivale-Baseline Gateway to unite the recently occupied Agriculture and Agri-food Canada buildings across Merivale Road with the rest of the site.

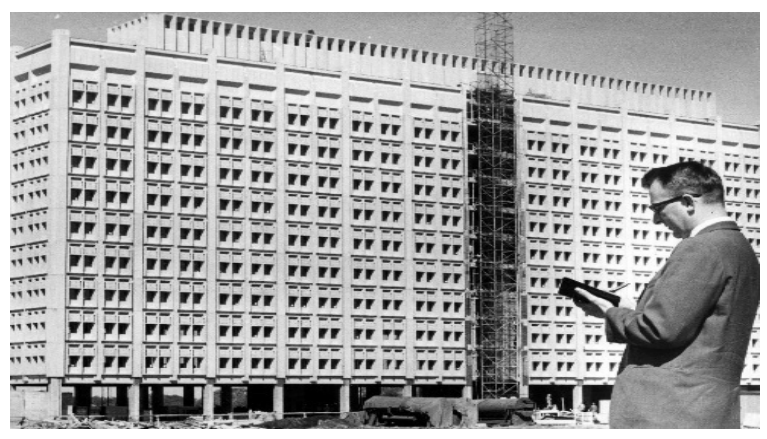

FIGURE 8

The under-construction Sir John Carling building (Photo: Ottawa Citizen, 1967).

\section{FORCES}

TECHNICAL

Lack of water supply to west side

\section{FORCES}

SOCIO-CULTURAL

Development of Merivale-

Baseline Gateway

\section{CHARACTER DEFINING ELEMENT}

BUILT FEATURES

Buildings named after key figures

in Canadian agriculture 
FIGURE 9

Conceptual render for the proposed National Botanical Garden (Image: Ottawa Citizen, 2016).

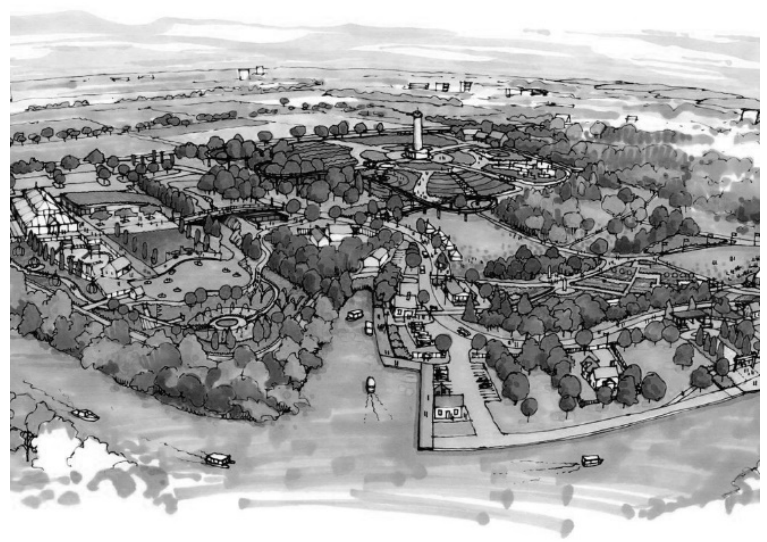

\section{| FIGURE 10}

Typical cross section of the proposed rapid-transit system for Baseline Road. The proposed plan will impede seven metres onto the Farm's research fields (Image: City of Ottawa, 2016).

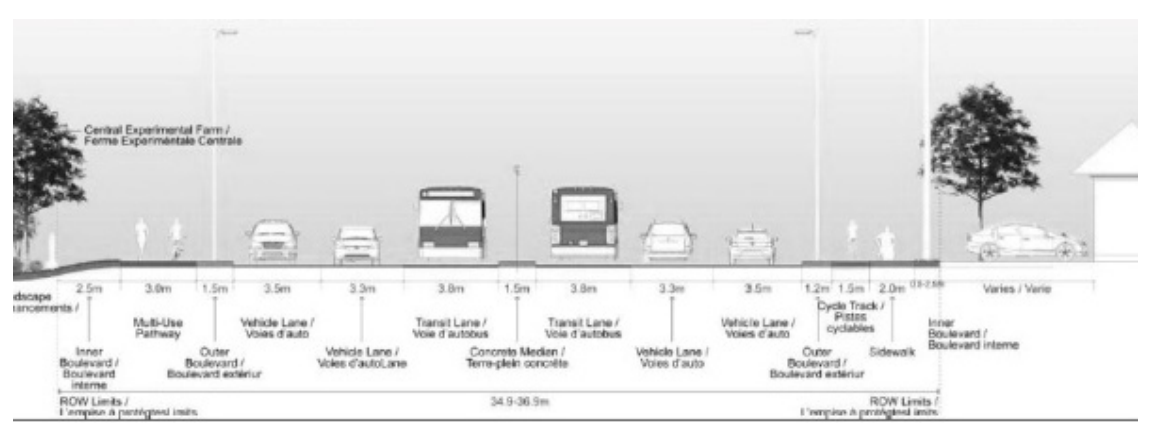

\section{FORCES}

ECONOMIC

Rapid Transitway development on Baseline Road and Carling Avenue

\section{FORCES}

NATURAL

Salt contamination to research plots adjacent to Baseline Road and Carling Avenue 


\subsection{History of the Landscape}

THE NATURAL LANDSCAPE 542,000,000 - 5,000 YEARS AGO

BEDROCK

CHAMPLAIN SEA

PRIMEVAL FOREST

SWAMP

The Ottawa Valley as we know it today is the result of glacial retreat which began 20,000 years ago. When the massive two to three-kilometre thick glacier began to melt 12,000 years ago, the Atlantic Ocean began to flow into the Ottawa Valley due to the depression caused by the heavy glacier, forming the brackish Champlain Sea. The Champlain Sea occupied the Valley for approximately 2,000 years, and as it drained exposed the underlying bedrock and carved the path of the modern Ottawa River. As the glaciers advanced and retreated in the period before their final melting, the bedrock was exposed in some places and glacial till was deposited in others. The landscape of the Farm has evidence of this changing landscape in its terrain features, from exposed bedrock to the diverse and varied soils which make up the research fields. The Sir John Carling building site is located on the Gloucester fault line, it the intersection of two types of limestone formed in the Paleozoic period (542-251,000,000 years ago). ${ }^{94}$

- BEDROCK PALEOZOIC

limestone, dolomite, sandstone

- GLACIAL DEPOSITS

till, plain

- CHAMPLAIN SEA SEDIMENTS

clay, silt

$\circ$

gravel, sand, boulders

POST-CHAMPLAIN SEA DEPOSITS

silty sand, clay

FIGURE 11

The evolution of the surficial geology of the Farm as indicated on Map 6.
CHARACTER DEFINING ELEMENT EVIDENCE OF LAND USE

Variety of soil types

\section{MEMORY}

LOCAL, REGIONAL

Primeval forest

94 Inside Ottawa Valley, "When continents collide our valley was formed." Inside Ottawa Valley. June 19, 2014. Accessed March 15, 2017. http://www.insideottawavalley.com/opinion-story/4587936-whencontinents-collide-our-valley-was-formed/. 


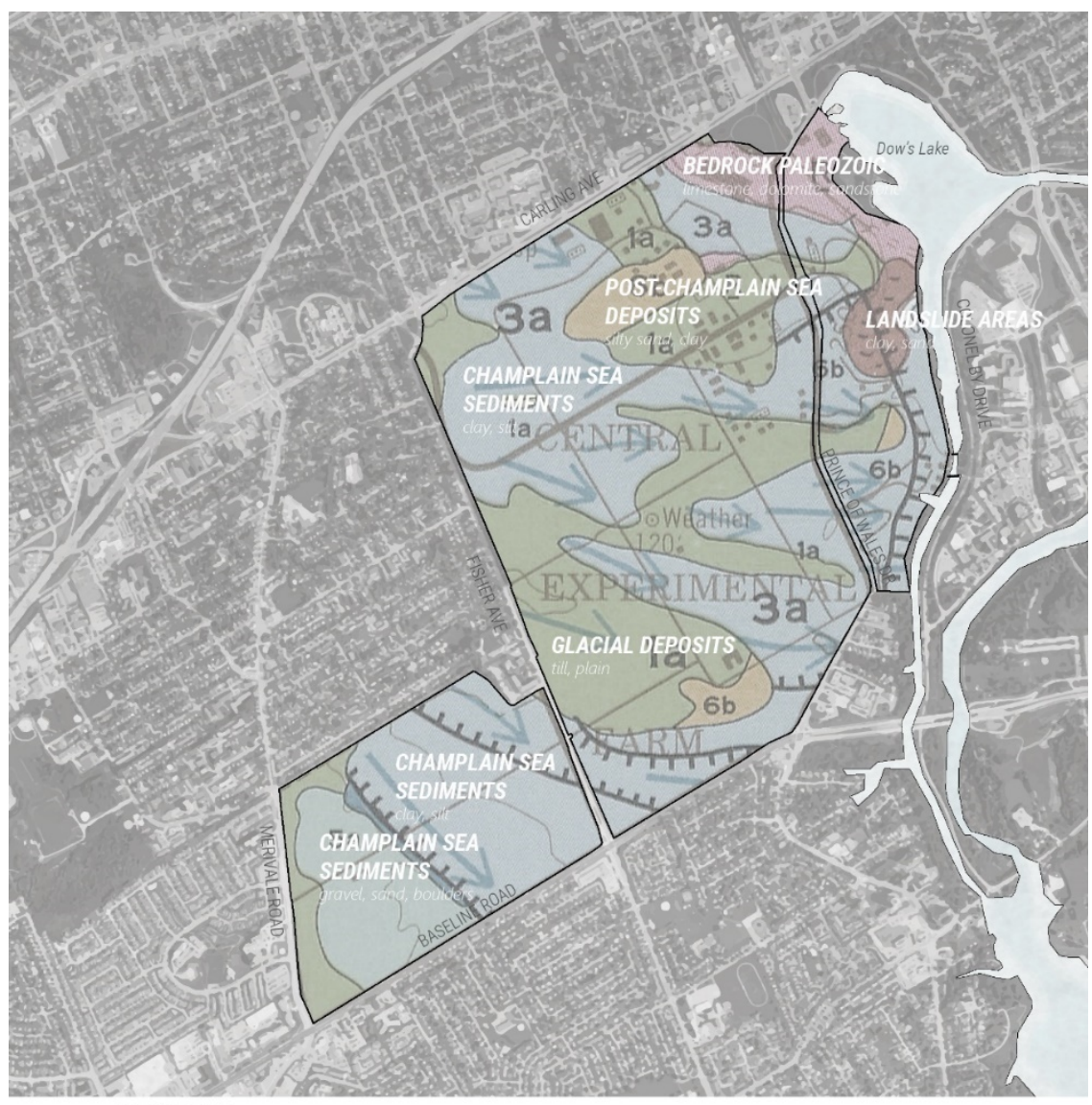

Farm
2017

| MAP 6 SURFICIAL GEOLOGY

The surficial geology of the Farm, ranging from the oldest bedrock to newer post-Champlain Sea deposits. Where the pink meets blue on the map indicated a fault line going through the Sir John Carling building site. 
The land was inhabited by First Nation populations, specifically the Algonquin for over 5,000 years, before settlement by Europeans. A seminomadic people, Algonquins lived on both sides of the Ottawa River, moving from one place to another for food and along the river for trade..$^{95}$ As they moved throughout the area to hunt, trap, fish, and gather food and did not setting up any permanent settlements, their physical impact on the landscape remained very minimal. As indicated in Section 2.3 the larger linguistic group of the Algonquians peoples practised more permanent management of the landscape through their traditional agriculture. The physical traces of these peoples greatly diminished since the arrival of Europeans (first sighting of Chaudière Falls by Étienne Brûlé in 1610) and has proved challenging to assess the developed land of Ottawa. Algonquins who laid claim to the land over 250 years ago never extinguished their title to the land with the signing of a treaty and therefore rightfully own much of the land of the Capital region. ${ }^{96}$

\footnotetext{
${ }^{95}$ Meredith Jean Black, "Algonquin." The Canadian Encyclopedia. Accessed March 03, 2017. http://www.thecanadianencyclopedia.ca/en/article/algonquin/.

96 John Paul Tasker. "Historic land deal with Algonquin peoples signed by federal, Ontario governments." CBCnews. October 18, 2016. Accessed March 11, 2017. http://www.cbc.ca/news/politics/ottawaontario-algonquin-agreement-in-principle-1.3809876.
}

\section{MEMORY}

LOCAL, REGIONAL

The use of the Ottawa River by First Nations to navigate seasonally around the region 
SWAMP

PRIMEVAL FOREST

TOWNSHIP OF NEPEAN

CLEARING

DAIRY FARMING

LIVESTOCK FARMING

TIMBER

The land selected for the Farm was outside of the borders of Ottawa, in the Township of Nepean. The area was first settled by Europeans in the late $18^{\text {th }}$ century due to land grants from the government, but the remoteness of the area made it difficult for permanent settlement. Although the township was first surveyed in 1792, the subsequent twenty years did not hold any permanent settlement until a small pioneer community developed in the first part of the $19^{\text {th }}$ century. See FIGURE 12 for the proximity of the Farm from the core of Ottawa and Gatineau area from 1810-1945. During the first half of the $19^{\text {th }}$ century, the large immigration of the Irish greatly increased the population in the area. A significant portion of the land was occupied by swampland, deterring development. Some of these swampy areas would be transformed into Dow's Lake, an artificial lake which routes the Rideau Canal northeast towards downtown Ottawa and the Ottawa River. Agriculture has a long history in the area and was the dominate industry during the township's early history. ${ }^{97}$ Early farmers grew wheat and harvested timber, but these crops were eventually traded in for dairy and livestock farming due to the dominant Prairie wheat production in the 1880's and 90's.

As seen in FIGURE 13, from the 1879 Carleton County Atlas, is one of the parcels of land which would become the Farm, as well as the roadway in the middle ground that would eventually become Prince of Wales Drive. At the top left of the image, the Centre Block and Tower (pre-1916 fire) can be seen on Parliament Hill, showing the symbolic and physical connection of the location of the Farm to the seat of government. In the top right background, a railway line (now the $\mathrm{O}$-Train line), Dow's Lake, and the Rideau Canal can be seen.

MEMORY LOCAL, REGIONAL

The early landscape of the Township of Nepean had a great deal of swampland which dictated the early planning of the area

${ }^{97}$ Bruce Elliott. The City Beyond: A History of Nepean, Birthplace of Canada's Capital, 1792-1990. Nepean, Ontario: City of Nepean, 1991, 30. 

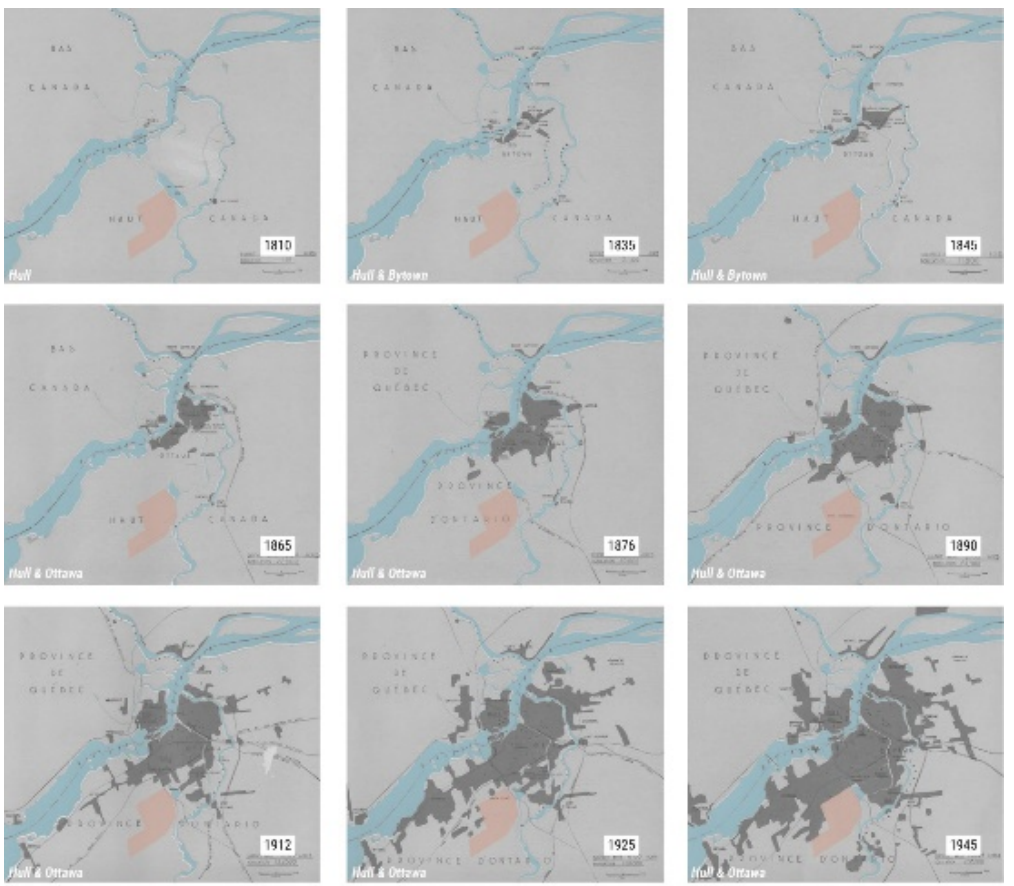

FIGURE 12

The growth of Ottawa and Gatineau from 1810 (top left) to 1945 (bottom right) towards the Farm (in orange) (Map: Gréber plan, 1950, edited by Little, 2017).

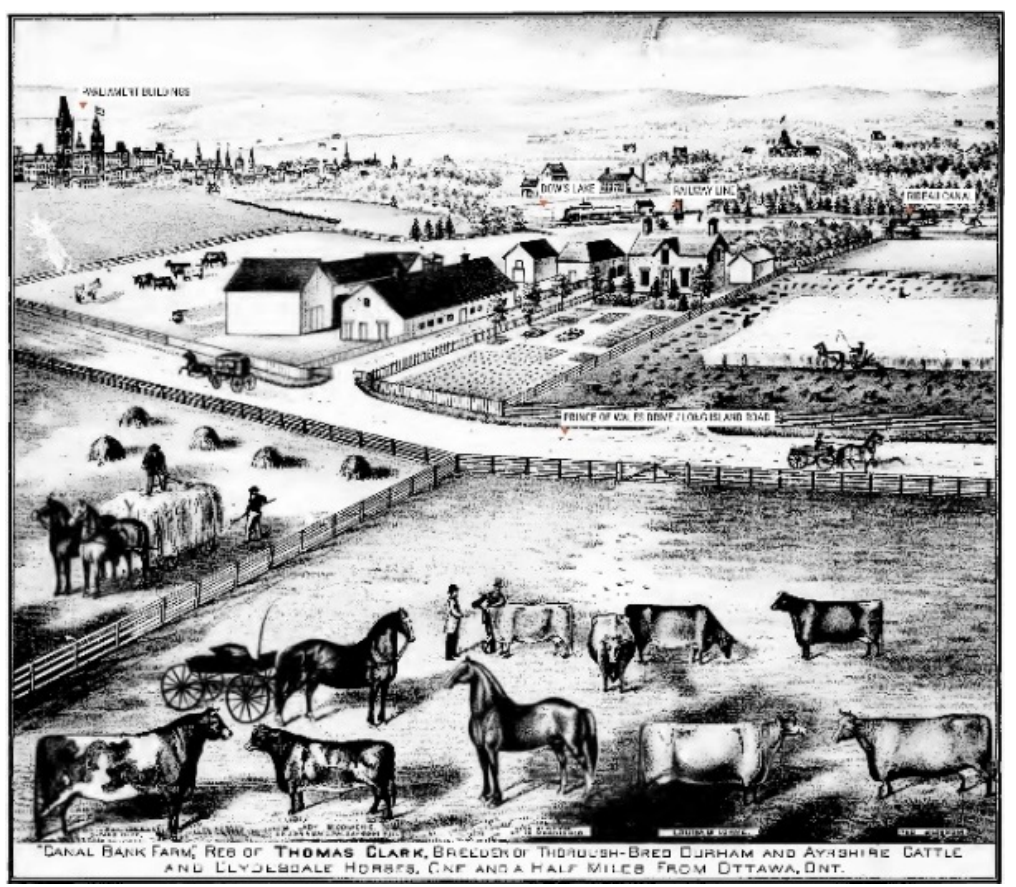

FIGURE 13

Artist's rendering of the Thomas Clark farm, part of the land which would become the Farm a few years later (Photo: Carleton County Atlas, 1879). 
On the next page MAP 7 shows the land acquired in 1886 for the Farm. The land acquired was privately owned, a large portion belonged to J.R. Booth, and contained a housing suburb called Nepeanville. The land was either sold to or expropriated by the Government to obtain for the Farm. The land at acquisition by the federal government was comprised of a mix of second growth forest, some 40 acres of swamp, developed farmland, and rocky terrain. ${ }^{98}$ It took approximately two years to get the land in suitable condition for agricultural research. FIGURE 14 shows some of the early labourors charged with prepping the "rough" landscape for farming, in which upwards of 5000 stumps of trees were removed with dynamite and the second growth trees were cut down and burned. ${ }^{99}$ In an 1888 report by Select Standing Committee on Agriculture and Colonization, the various types of soil and their properties are mentioned as well as blasting through rock to allow for better drainage. The report documents the implementation of drainage tiles in areas of clay soil, reporting these areas are now some of the best drained areas of the Farm. ${ }^{100}$ The "almost virgin" soil was commended by Saunders as experiments would not be affected by previous fertilizers and manures used on the land. ${ }^{101}$

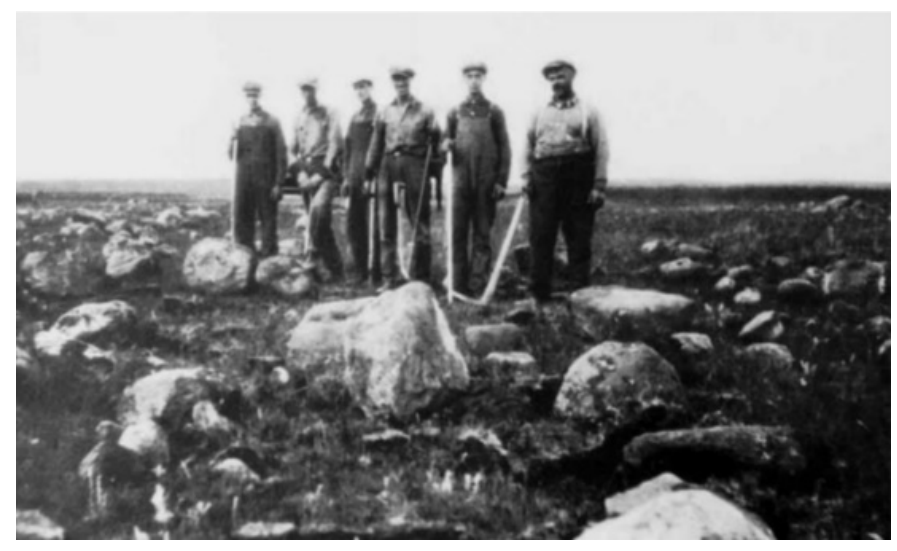

FIGURE 14

Photograph of the labourers who transformed the rough landscape in to "rich undulating plain" (Photo: Blooms by Richards Hinchcliff, 2016).

\section{MEMORY}

LOCAL, REGIONAL

A large portion of the acquired land for the Farm was comprised of swampland

\section{MEMORY}

LOCAL

A portion of the acquired land for the Farm was comprised of second growth forest

${ }_{98}$ Report of the Select Standing Committee on Agriculture and Colonization of the House of Commons, Second Session, Sixth Parliament. Ottawa: Queen's Printer, 1888.

${ }^{99}$ T. H. Anstey, One Hundred Harvests: Research Branch, Agriculture Canada, 1886-1986. Ottawa: Minister of

${ }^{100} \mathrm{Ibid}$. Supply and Services, 1986, 12. 


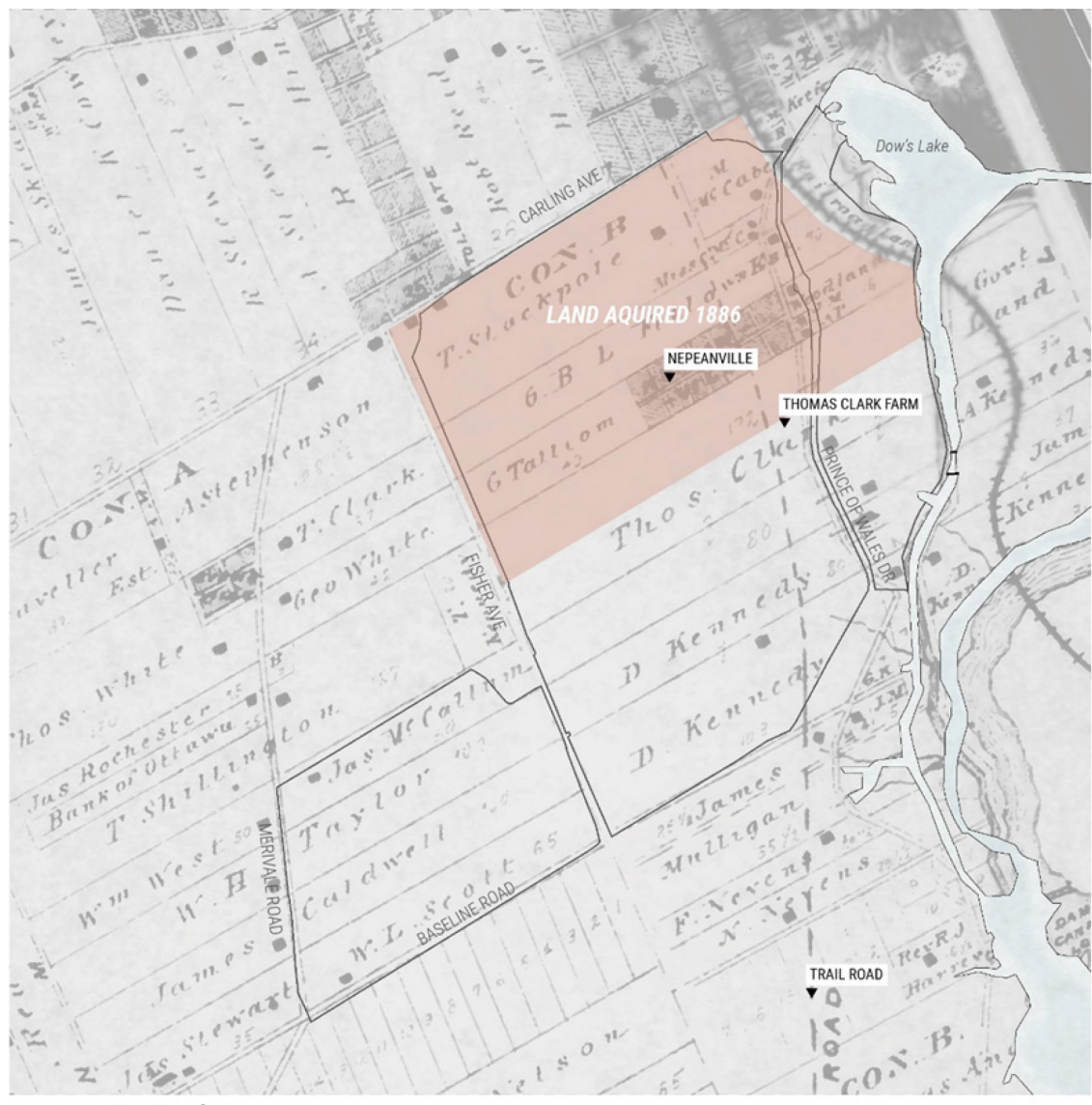

\section{Farm Boundary}

MAP 7 LAND USE 1879

In 1886, the federal government chose 400 hectares of land, located three kilometers from Parliament Hill and well outside Ottawa's boundaries (Figure 11) for the location of the new federally run Central Experimental Farm. The site was selected for its proximity to Parliament Hill, wide variety soil types, access to a railway, water, roads, and climatic conditions which represented both Ontario and Québec. 102 The 400 acres of land acquired in 1886 by the federal government overlaid on an 1879 land survey shows a mix of privately owned farms and housing developments. The Thomas Clark farm, as indicated in FIGURE 12, is on the southernmost side of the acquired land.

\section{CHARACTER DEFINTING EHEMENT}

LAND PATTERNS

Location in the urban centre of Ottawa

102 HistoricPlaces.ca - HistoricPlaces.ca, accessed January 02, 2017, http://www.historicplaces.ca/en/repreg/place-lieu. aspx?id=13811. 


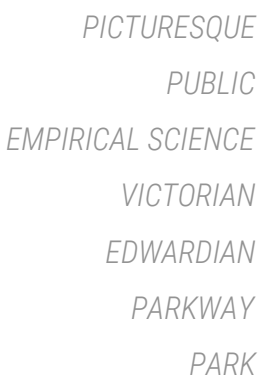

The first recorded plan of the Farm was drawn in 1886, showing a model farm set in a Picturesque landscape and is characteristic of the Victorian period's philosophy of agriculture, science, and lifestyle (MAP 8). The Picturesque aesthetic of the Farm was the result of "theorists and practitioners who sought to bring landscape design closer to an idealized nature" as popularised in England in the late $18^{\text {th }}$ century. ${ }^{103}$ The Farm shows characteristics of an English country estate such as large stretches of lawn and fields, groupings of trees and shrubs, and winding paths. This philosophy of the landscape is visible in an early promotional image for the Farm (FIGURE 14). The goal of this aesthetic approach was to enhance the "inherent beauty" of nature. A report writes of the grounds of the entry area of the farm in 1909: "The gardens look as though they grew as nature planed them...There are simplicity, unity, and beauty everywhere."104 (FIGURE 15). Techniques of the Picturesque include the emphasis on colour, shape, material, and texture, so the individual parts work together in a composition. ${ }^{105}$ Another aspect of the Picturesque aesthetic is the controlled revealing of elements. For example, a sequence or journey leading up to a breathtaking vista.

The Picturesque aesthetic extended beyond the design of the Farm towards a characteristic federal vocabulary at the beginning of the $20^{\text {th }}$ century. In 1899 the Ottawa Improvement Commission (IOC) was established by Prime Minister Wilfrid Laurier, who ordered the "beautification" of the unattractive industrial city to express the image of a National Capital. ${ }^{106}$ Frederick Todd was employed in 1903 to plan the National Capital Region. Todd importantly distinguished between beautiful and picturesque planning: the beautiful is the result of "result of proportion, utility, or perfection," whereas the picturesque "forms a picture." Todd advocated for a picturesque Capital in his planning. Although the IOC did not immediately adopt his work, much of his plans have been gradually incorporated into the capital.
CHARACTER DEFINING ELEMENT TRADITIONAL PRACTICES The orderly and efficient layout of a "model farm"

\section{CHARACTER DEFINING ELEMENT}

SPATIAL ORGANIZATION

The Picturesque nature of the site

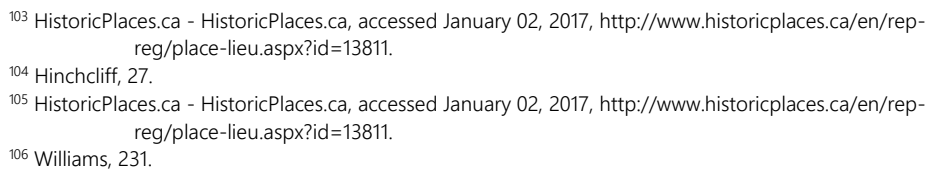


Part of the regime for this picturesque Capital was the development of a network of parks and parkways to extend through the Capital (FIGURE 16). Notably, the pre-existing Queen Elizabeth Driveway was extended from Lansdowne Park to the Farm, allowing the uninterrupted connection between Parliament Hill and the Director's Residence. ${ }^{107}$

Sharing the discoveries of science during this period was a fundamental aspect of the Victorian period. Information was made accessible to many audiences, and the public was invited into the grounds of this Central Experimental Park, as it was often called. ${ }^{108}$ However, it is important to acknowledge that the public grounds of the Farm were the Arbouretum, the Ornamental Gardens, and the area around the Central Lawn. It was not until decades later when the Farm was fully surrounded by the city that the Research Fields would be used as a park by citizens of Ottawa.

\section{CHARACTER DEFINING ELEMIENT} CIRCULATION Integration of urban parkways within the agricultural landscape

${ }^{107}$ Williams, 232.

108 Helen Smith et al., Ottawa's Farm: A History of the Central Experimental Farm. Burnstown, Ontario: General Store Pub. House, 1996. 
FIGURE 14

An artist's rendering of the "model farm" set in a Picturesque landscape (Photo: Agriculture and Agri-food Canada, 1890).

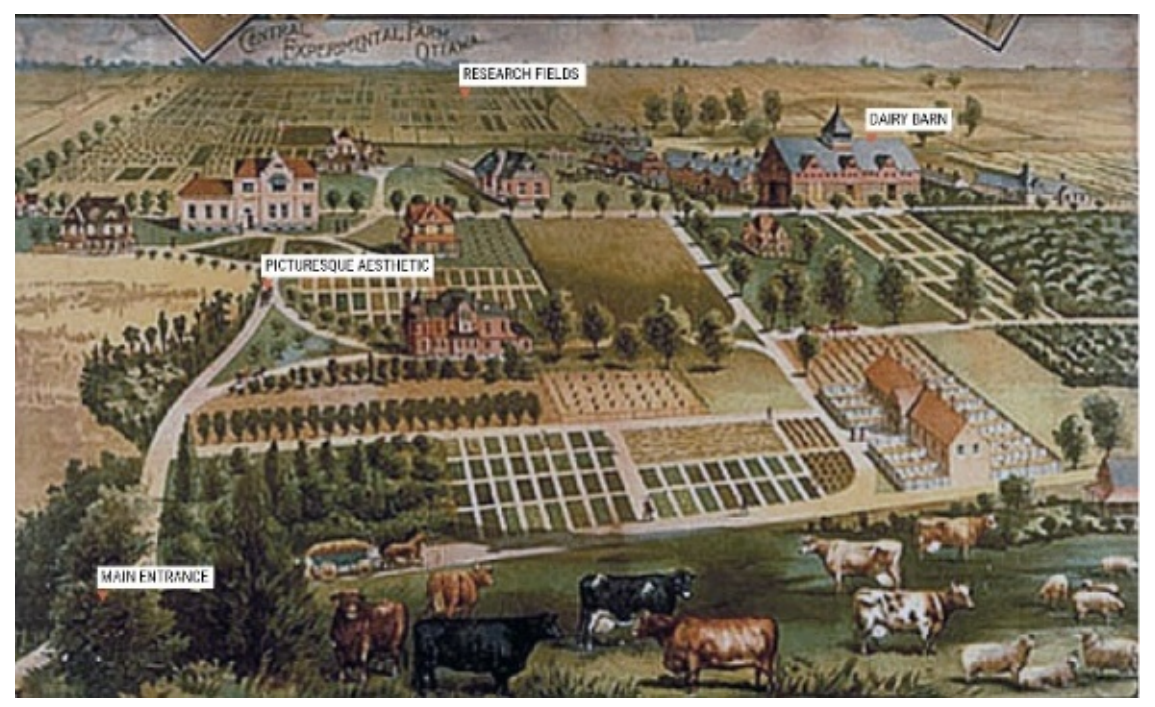

FIGURE 15

The Ornamental Gardens in the late 1880's and a lawn behind. At the far right the Dairy Barn and a residence (Building 54) are visible (Photo: Blooms, Richard Hinchcliff).

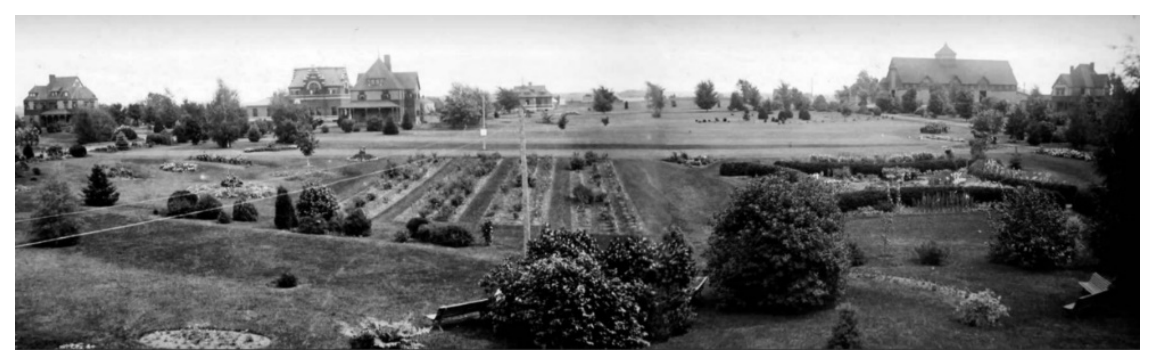


FIGURE 16

Todd's 1903 Plan extending a network of parks and parkways throughout the Capital Region. (Map: Queen's University).

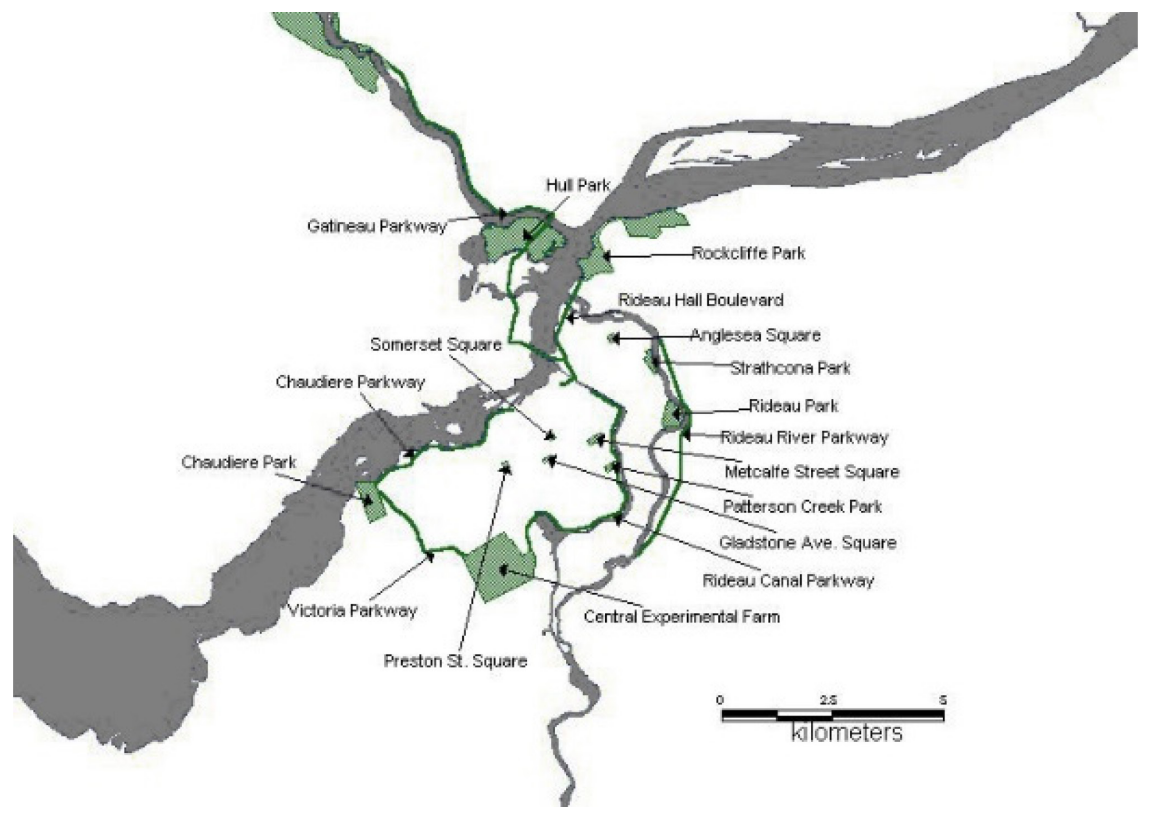




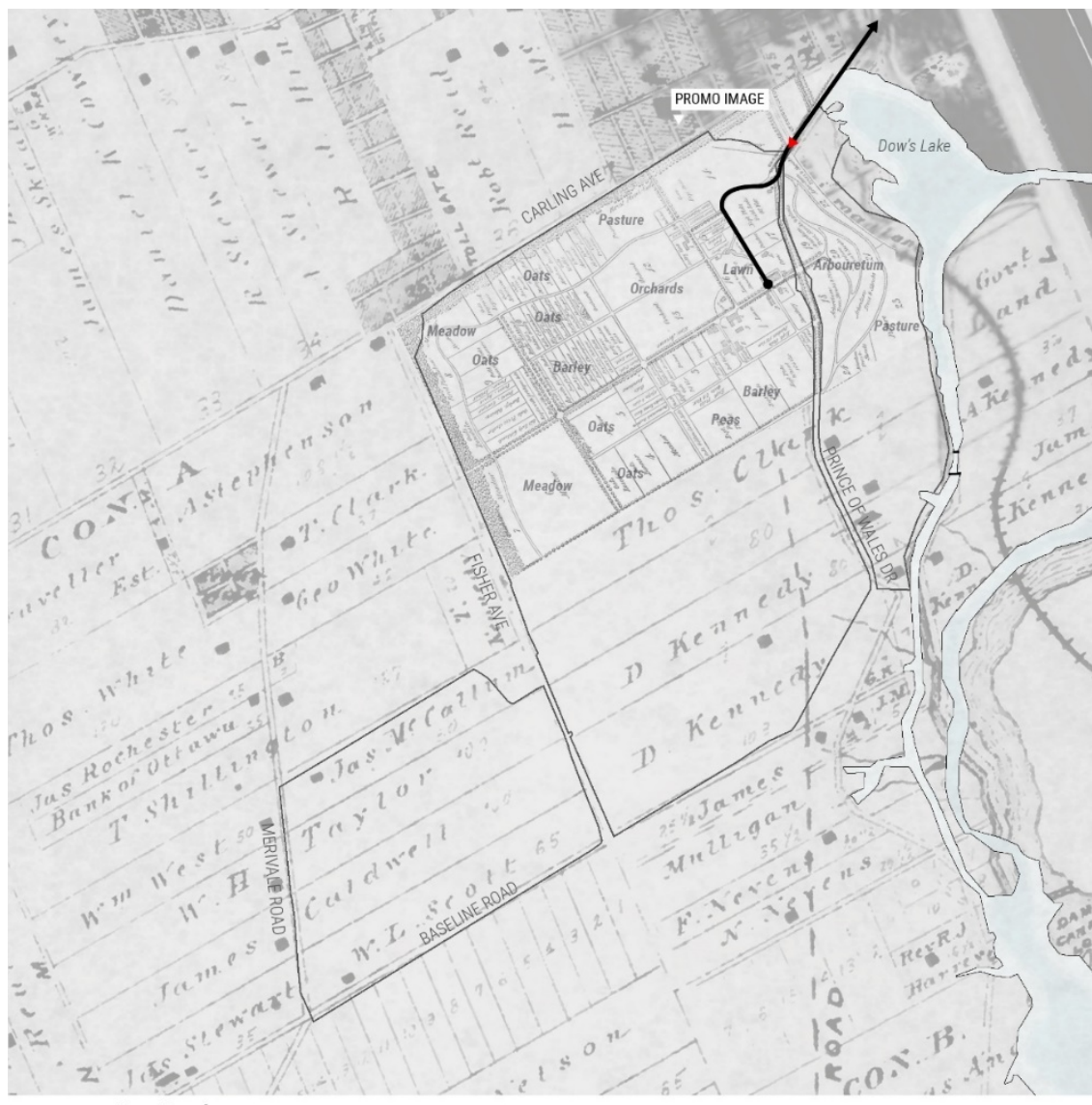

Farm

MAP 8 LAND USE 1886

The location of the promotional image from Figure 14 is indicated on the map. The location of this perspective was key to the approach of the early planning of the Farm. Visitors would arrive from the north-east Queen Elizabeth Drive, as indicated in red, entering to the Picturesque setting of the Director's House, Administrative Buildings, and Farm structures. The rectilinear research fields appear to extend infinitely into the distance beyond. The tree lined roads of Ash Lane and presently NCC Scenic Driveway, as well as the shelterbelts are characteristic of the early philosophies and ambitions of the Farm.

\section{CHARACTER DEFINING ELEMIENT}

\section{BUILT FEATURES}

Picturesque setting of the wood-clad administrative buildings

\section{CHARACTER DEFINING ELEMENT}

EVIDENCE OF LAND USE / LANDFORMS

Orderly organization of the fields

\section{CHARACTER DEFINING ELEMENI}

\section{VEGETATION}

Shelterbelts 
DECENTRALIZATION

INDOOR FACILITIES

PRIVATE

DEMOLITION

MODERN BUILDINGS

THEORETICAL SCIENCE

URBAN SURROUNDING

Beginning in 1936, the Farm evolved into the second phase of the cultural landscape stated by the Management Plan; the Farm evolved into "a landscape where there was still one central idea, about research, but changing ways in which that idea was expressed in the physical architecture and landscape of the place." ${ }^{109}$ It began with the demolishing of the Director's Residence and replacement with the Saunders's Building (FIGURE 17). The Director's residence which faced and welcomed visitors from the north-east approach was replaced with the inward oriented Saunders' Building. This planning also represented the movement of science at the time from a more publicly oriented, empiricist idea to more theoretical. ${ }^{110}$ The Farm was no longer, the main source of agricultural innovation in the country as the decentralisation of administration gave other stations more responsibility to coordinate their own research. The end to tobacco research in 1958, forestry research in 1960, and the moving of animal research to another facility resulted in the demolition of several original buildings and the construction of new modern structures. ${ }^{111}$

Urban development pressure is not new to the Farm. As exhibited in the Jacques Gréber's 1950 plan for the Capital, the Farm was to be reduced to its original size. Gréber greatly undervalued the significance of this historic landscape in its entirely. Gréber acknowledged the significance and importance of the NCC Driveway (FIGURE 18) as a scenic gesture through the site, however, designated much of the remaining area to public open space, parks, and playgrounds. ${ }^{112}$ The severed area of the Farm was to be subdivided for housing. See MAP 9 and 10 which compare the differences of the proposed and implemented Gréber Plan, and MAP 11 which shows urban fabric surrounding the site on all sides in the 1960's.

\footnotetext{
${ }^{109}$ Central Experimental Farm Integrated Services; Agriculture and Agri-Food Canada; Government of Canada. "Central Experimental Farm National Historic Site Management Plan (9 of 20)."

$110 \mathrm{lbid}$.

$111 \mathrm{lbid},(4$ of 20).

${ }^{112}$ Gréber, Jacques. General Report Submitted to the Nation Capital Planning Committee. Ottawa: National Capital Planning Service Ottawa, 1949.
} 
During this period, there was a sense that the science had "moved indoors, to controlled environments." ${ }^{113}$ The previously public feeling began to disappear due to the removal of a public auditorium and public transportation to the site. The Picturesque planning of the early landscape had been replaced with the functionality of mid-century planning, along with other Picturesque elements such as the shelterbelts along Carling Avenue, which were removed due to the spread of the Dutch elm disease in the middle of the century. ${ }^{114}$ The disappearance of the shelterbelt plantings along Carling Avenue can be seen in FIGURE 19 and 20.

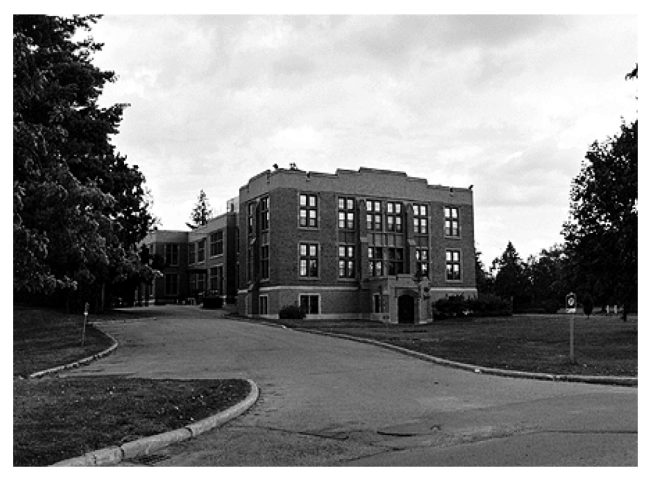

FIGURE 17

The Saunders' Building built 1936 oriented away from the public entry simultaneously represented the shift in scientific theory (Photo: AAFC).

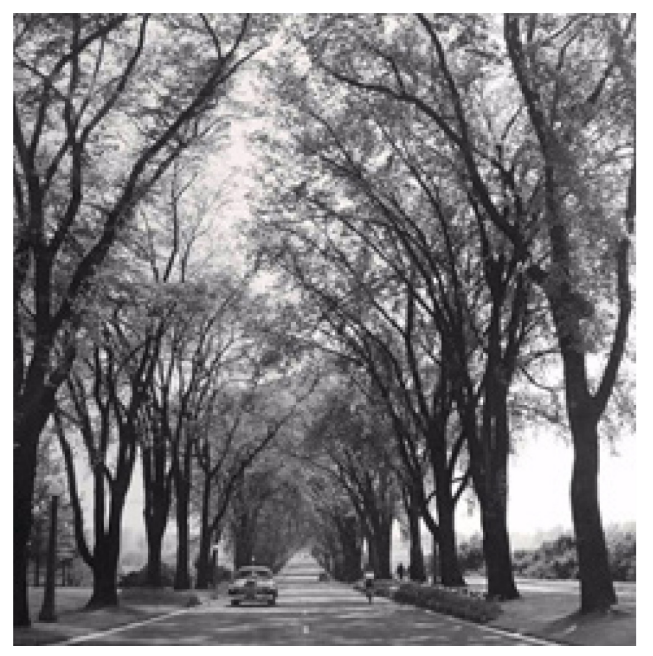

FIGURE 18

The NCC Driveway in the 1950's (Photo: Blooms, Richard Hinchcliff)

\section{MEMORY}

LOCAL

Shelterbelts along Carling Avenue

\section{CHARACTER DEFINING ELEMENT}

VEGETATION

Shelterbelts
FORCES

SOCIO-CULTURAL

Orientation of program away from the Northeast and subsequent

less public image of the place

CHARACTER DEFINING ELEMENI

SPATIAL ORGANIZATION

Intimate campus-like scale of

Central Zone

\footnotetext{
${ }^{113}$ Central Experimental Farm Integrated Services; Agriculture and Agri-Food Canada; Government of Canada "Central Experimental Farm National Historic Site Management Plan (5 of 20)."

${ }^{114} \mathrm{lbid}$
} 


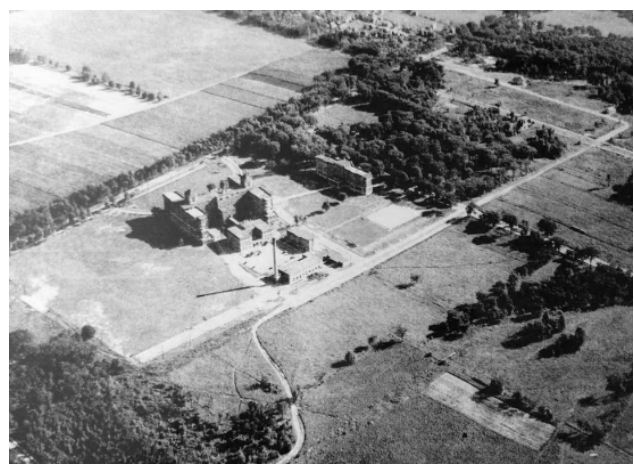

FIGURE 19

Aerial View of Civic Hospital in 1924 (Photo: Flickr.com, Dunn)

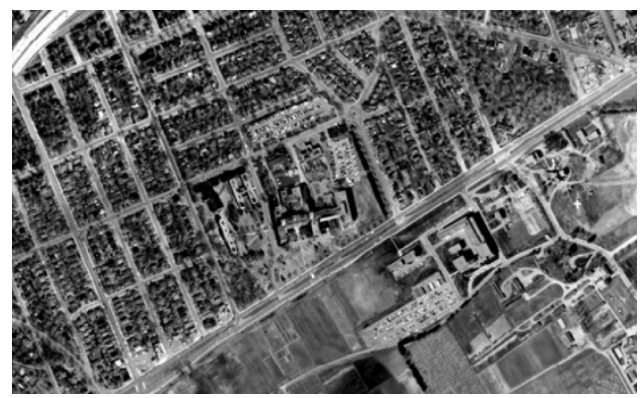

CHARACTER DEFINTNG EIEMENT VEGETATION Shelterbelts

\section{MEMORY} LOCAL

Shelterbelts along Carling Avenue

| FIGURE 20

Site Plan of Civic Hospital in 1965. (Photo: GeoOttawa) 


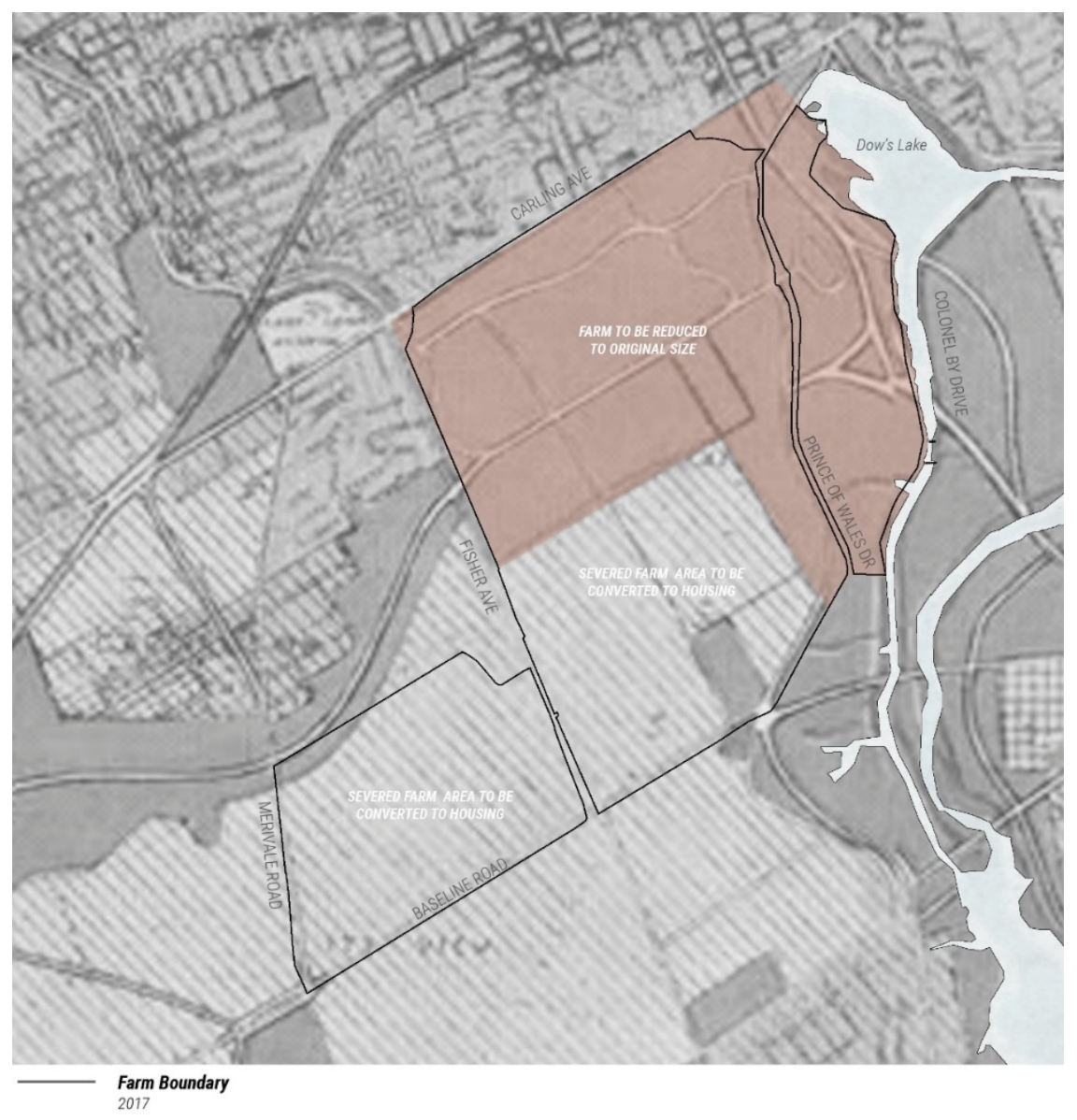

MAP 9 PROPOSED LAND USE 1950 GRÉBER PLAN

The proposed area for the Farm as per the 1950 Gréber Plan. The plan was not implemented on the Farm. 


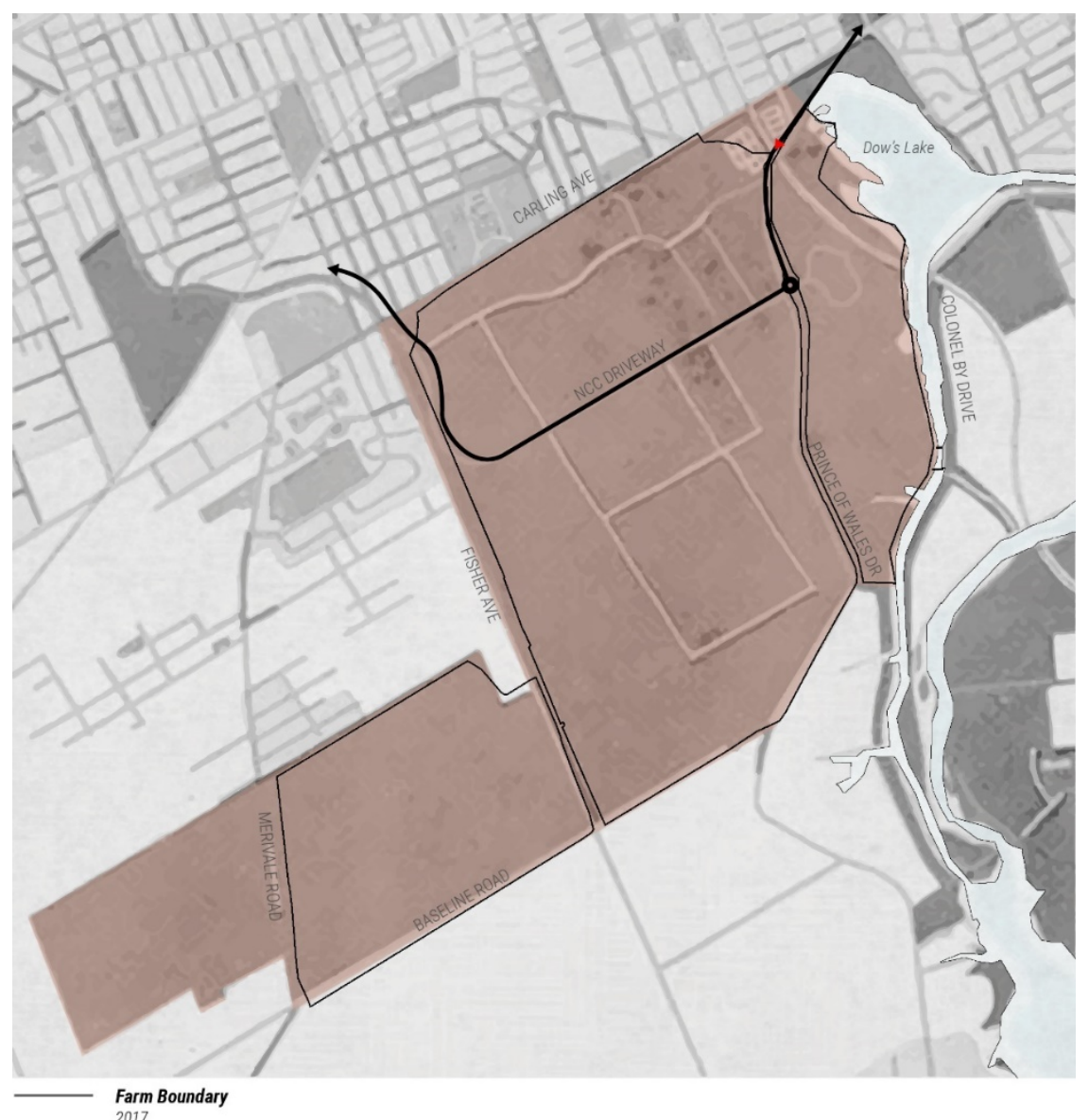

2017

MAP 10 LAND USE 1950

The actual land use plan of 1950 retained the Farm in its entirely, although this evolved landscape shows differences from the original designed landscape. Mainly the orientation of program away from the north-east, and consequent loss of entry. This period also saw the addition of 140 acres of research field to the west of the site. 


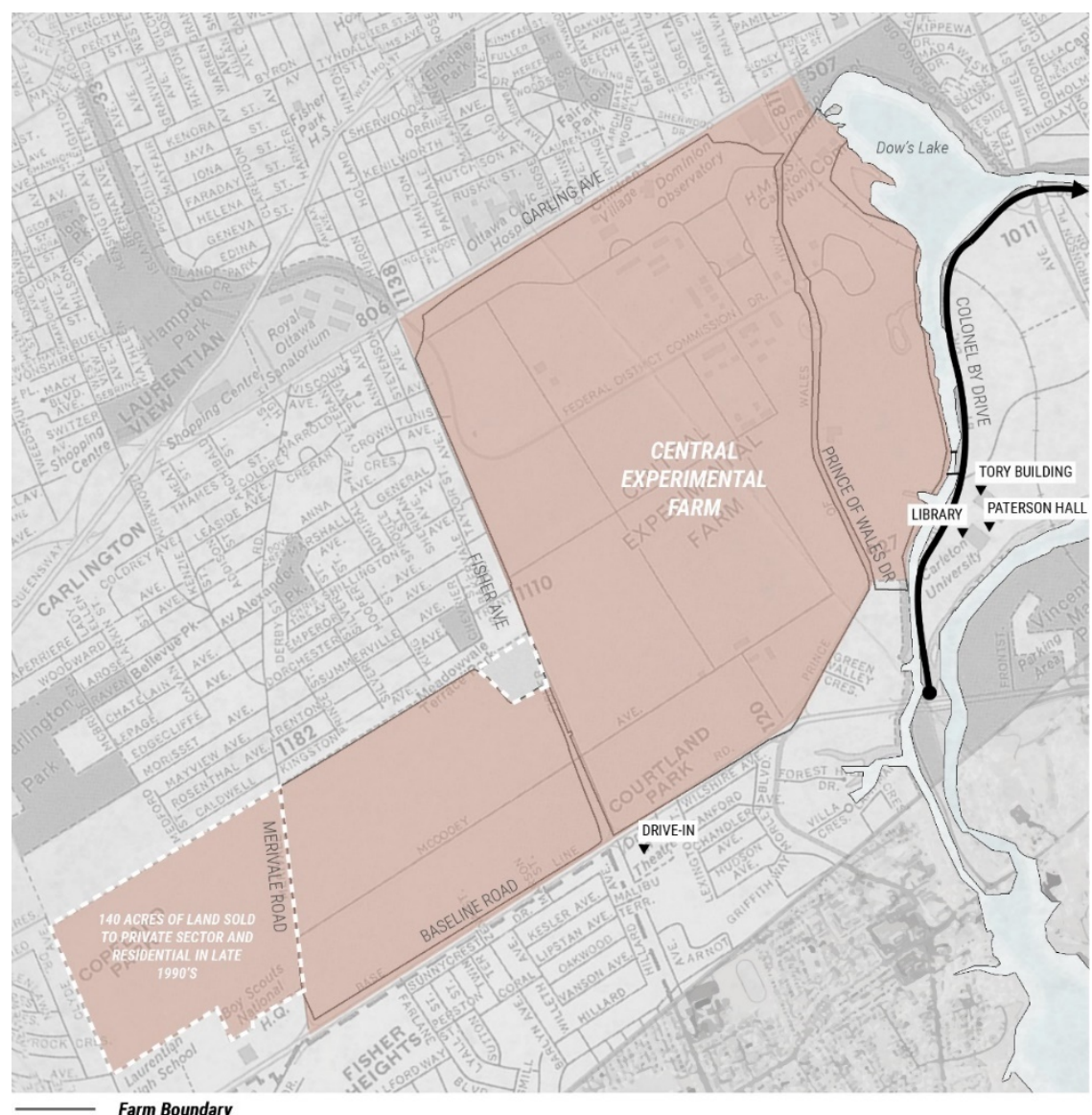

2017

MAP 11 LAND USE 1960'S

The 1960's saw the city of Ottawa grow around the Farm encompassing it on all sites, and was comprised mostly of residential development. The development on the west side of the site was due to the establishment of the Carleton University campus (previously Carleton College located in The Glebe). The university, The Civic Hospital (1920's), and the government offices at Preston Street would begin to form an institution identity around the Farm. 
The associative landscape phase began with the 100-year celebration of the Farm in 1986, as overlapping layers of meaning began to form around the agricultural landscape. The centennial raised awareness of the historic landscape, as well as questions regarding the research directions, and public ownership of the Farm. ${ }^{115}$ This period saw the opening of the Canadian Agriculture Museum in 1983, and its expansion to include live animal displays in 1995. ${ }^{116}$ The increased public awareness of the Farm initiated several community groups dedicated to the maintenance and protection of this historic landscape such as the Friends of the Farm (1988) and the Ottawa Chapter of Landscape Ontario (1973). This awareness also brought about renewed support for the Ottawa Field-Naturalists' Club (1863) who in 1990 began the Fletcher Wildlife Garden. ${ }^{117}$ In the 1990's a significant portion (140 acres) on the west side of the Farm was severed off for commercial and residential development. To recognise the legacy of the Farm, the site received designation a National Historic Site of Canada in 1997. A few masterplan and management plans have been outlined for the Farm since designation as a heritage place. The most recent Central Experimental Farm Management Plan (2004) was developed to "rather than simply respond to development proposals and development pressures... to take a lead role in shaping the future of the Farm environment.." ${ }^{118}$ See Section 3.1 for Maps of Existing Context.

115 Central Experimental Farm Integrated Services; Agriculture and Agri-Food Canada; Government of Canada. "Central Experimental Farm National Historic Site Management Plan (5 of 20)."

116 Ibid

117 Ibid.

${ }^{118}$ Ibid. 


\subsection{Character Defining Elements}

The heritage value of the Farm, as stated in the Introduction, lies in the composition of its natural, built, and landscaped elements which together define its character as a distinct cultural landscape. As shown in Section 3.1 (MAP 1) the farm is comprised of three distinct landscaped areas and therefore have characteristics which are unique to each. ${ }^{119}$ The subsections from the Guidelines for the Conservations of Cultural Landscapes are listed beside the character defining element. The subsection of water features does not apply to the character defining elements of the Farm.

\section{Whole Site}

Location in the urban centre of Ottawa

Variety of soil types, cleared fields, and various buildings

Pastoral appearance

Orderliness and neatness critical to the Farm's scientific pursuits

Plan made up of three clearly defined zones

Picturesque character of buildings

Land patterns

Evidence of land use

Spatial organization

Land patterns

Spatial organization

Built features

\section{Entry Zone}

Picturesque nature of the site

The circulation pattern in the Arbouretum

Glass and metal greenhouse frames

The Arbouretum's wide variety of specimen trees and shrubs

\section{Central Zone}

Intimate campus-like scale

Scenic driveways

Picturesque wood-clad administrative buildings

Buildings named after key figures in Canadian agriculture

Small, single story board and batten style support buildings

The orderly and efficient layout of a "model farm"

\section{Support Zone}

Orderly organization of the fields

Internal fencing of red "pencil posts" with white tops

Built features

Variable sizes, colours, textures, seasonal variations of fields

Land patterns

Integration of urban parkway within farm

Circulation

Shelterbelts

Vegetation

Brick-clad science and administration buildings

Built features

Viewscapes

Visual relationships

${ }^{119}$ Central Experimental Farm Integrated Services; Agriculture and Agri-Food Canada; Government of Canada. "Central Experimental Farm National Historic Site Management Plan (5 of 20)." 


\subsection{Existing Pedestrian Experience}

\section{FIGURE 21 INHABITANTS OF THE SITE}

The uses range from daily frequency to one times users. The largest group of people that frequent the Farm daily are the employees of Agriculture and Agri-food Canada, NRC, The Canadian Agriculture Museum, and the Friends of the Farm and their volunteers. There are also many commuters and casual visitors to the site including walkers, bikers, and dog walkers.

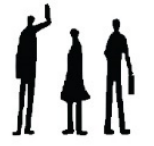

Field employees and volunteers

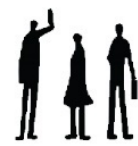

Office employees and volunteers

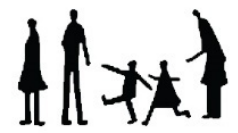

Organized group visits / tours

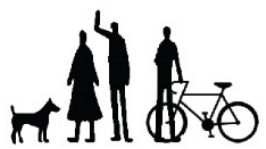

Daily casual visitors and commuters
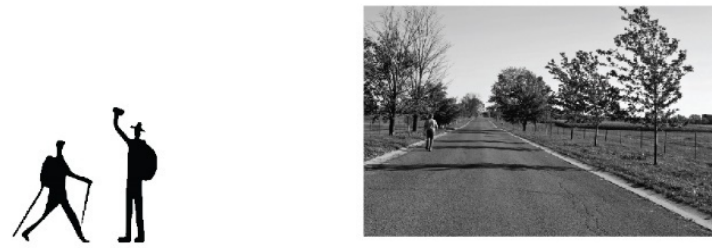

Local or foreign tourists 
There are five scenarios of the current and potential users of the Farm site - they are not definite, but offer the potential experience of users in each category. The darker grey circles indicate the users' potential interaction with a scenic pathway system during their visit to, or through the site. The employees and volunteers who frequent the Farm daily, travel to the site by a variety of means including foot, bike, transit, or car. Employee interaction with the research field areas - the main area of the scenic pathways - varies greatly depending on sector and season.

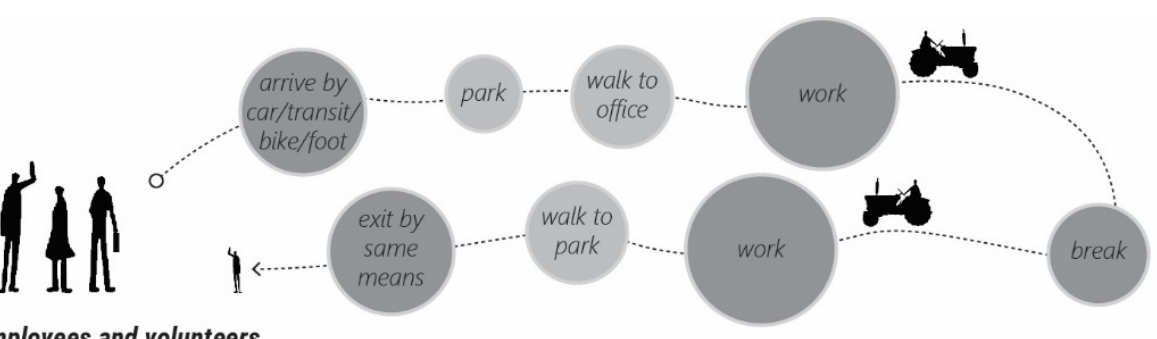

Field employees and volunteers

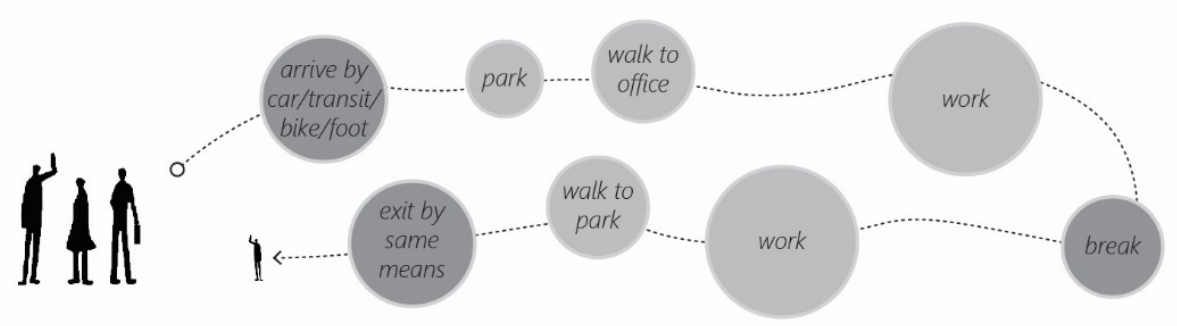

Office employees and volunteers

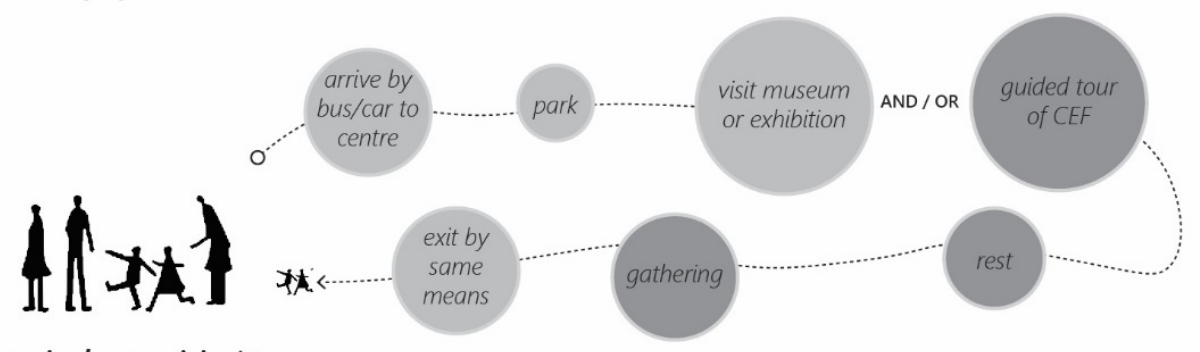

Organized group visits / tours

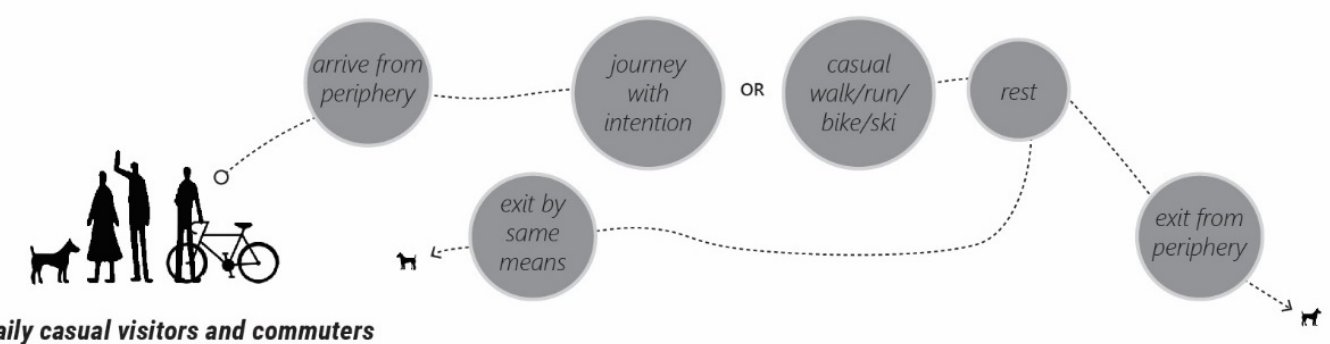

Daily casual visitors and commuters

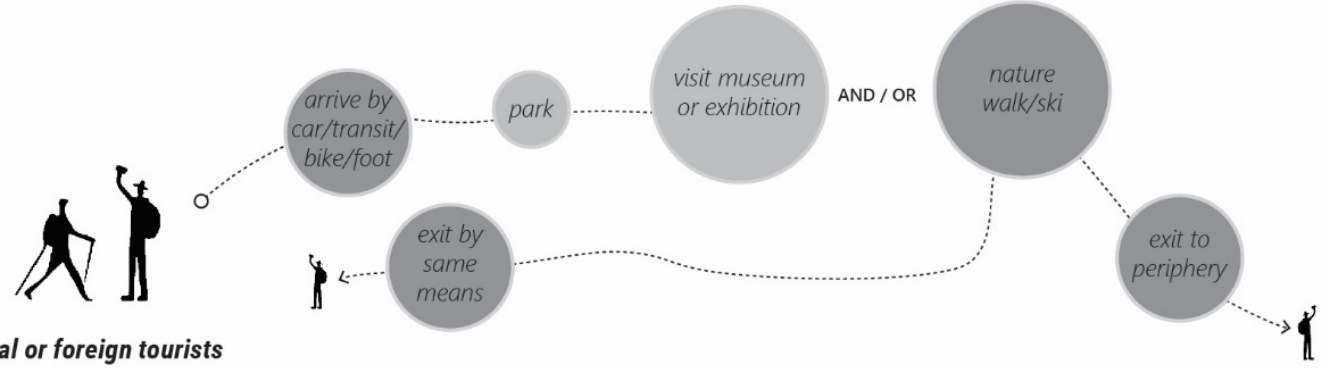


The types of pathways available to pedestrians include: farms roads in the research fields, roadways for bikers and sidewalks for pedestrians in the central area, trails and informal pathways, and the Experimental Farm Pathway and Merivale Shelterbelt Pathway. Throughout the warmer seasons, the pathways are accessible, clear, and safe for pedestrians, however in the peak seasons and winter, many of the pathways become unusable because of snow coverage, flooding, summer heat, or unbearable winds. The pathways which are the most comfortable and accommodate the most types of pedestrians throughout the year are the sidewalks throughout the central area and the Merivale Shelterbelt Pathway which provide a degree of shelter, visual variety, accessible entrances, and safe paving materials.

\section{(x)}

Farm Road

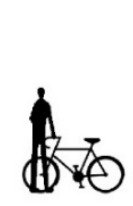

Roadway
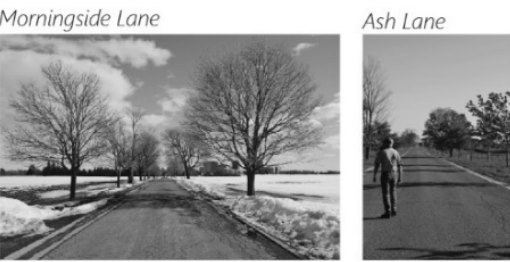

促A

Sidewalks

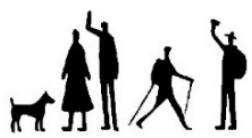

Trails / unmarked pathways
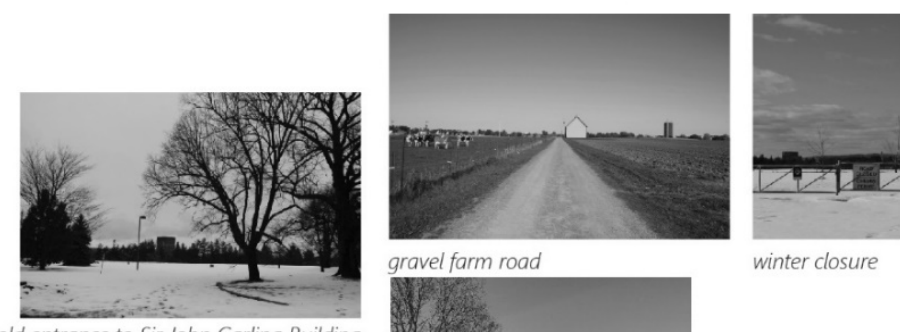

gravel farm road

winter closure
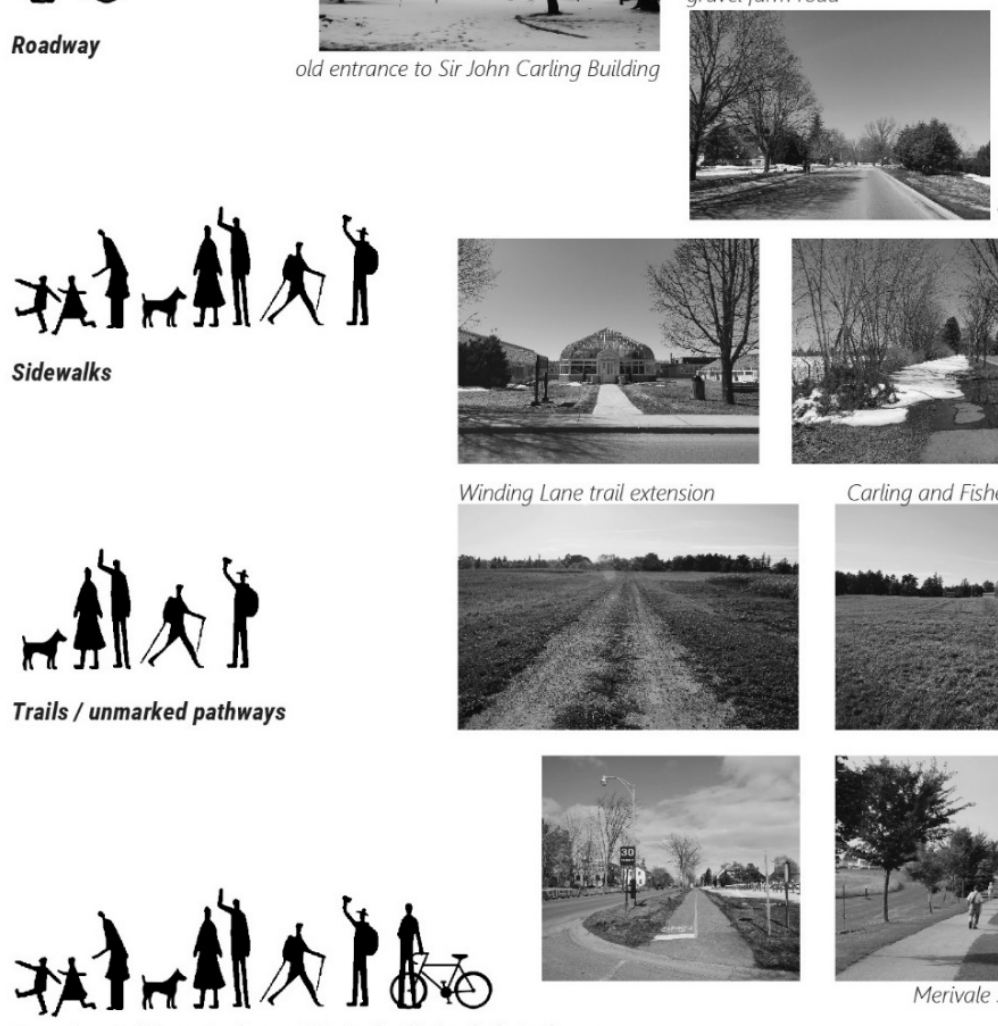

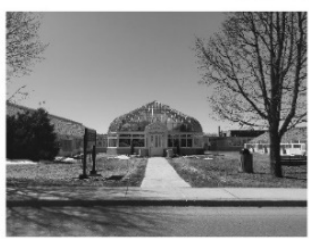

Winding Lane trail extension
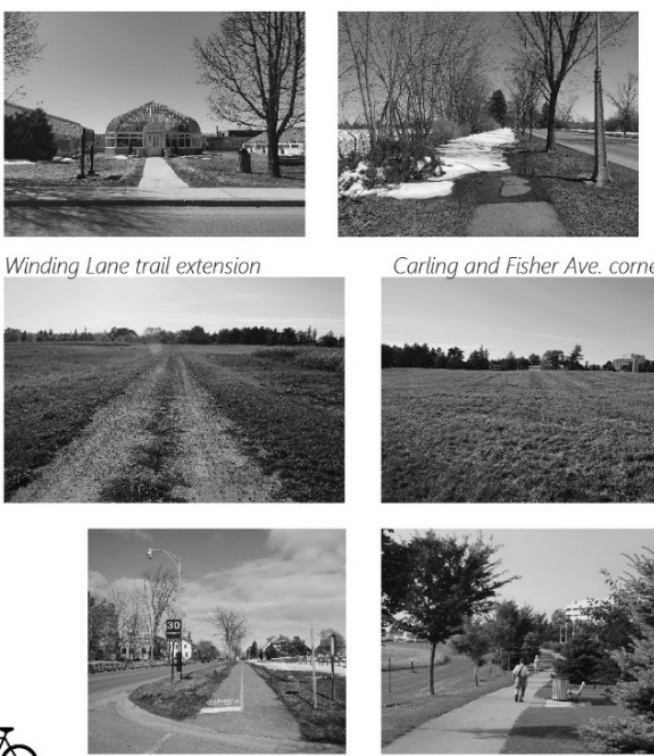

Carling and Fisher Ave. corner
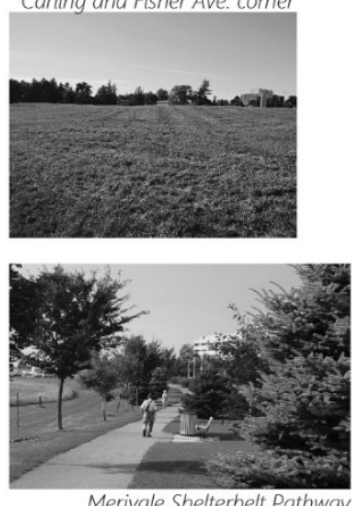

Merivale Shelterbelt Pathway

Experimental Farm Pathway / Merivale Shelterbelt Pathway 


\subsection{Precedent Study}

$\begin{array}{ll}\text { PROJECT NAME } & \text { National Tourist Routes } \\ \text { ARCHITECT } & \text { Various } \\ \text { DATE } & 1994 \text { - Present } \\ \text { LOCATION } & \text { Norway }\end{array}$

The Nation Tourist Routes are a collection of 18 highways with architectural attractions in Norway. The goal of the project is to increase tourist visitation to the locations through designed viewpoints, places of interest, pathways, and visitors' centres, all which are located amongst breathtaking landscapes and scenery. The project is of national scale with the subject locations spanning across the countries west coast and southern mountains. The project began in 1994 and continues development today with new attractions designed and constructed along the highway routes. The project was carried out by the Norwegian Public Roads Administration.

The design of the attractions expresses a vernacular specific to each site. Each location has specific values which are enhanced by the architecture and directs the visitor's experience to the place: "The architecture should facilitate the experience of nature, while also appearing as an attraction in its own right." 120 The FIGURE 1, 2, and 3 on the left show three of the many architectural attractions along the National Tourist Routes. This precedent study applies to this thesis by using pedestrian scale interventions in the landscape to enhance one's relationship with the landscape. The attractions themselves are not commercial or museum-like in nature, yet attract people to the place by showing the landscapes through a new perspective. Some of these landscapes are the scenes of everyday life, yet showing them in a new light causes people to stop, think, and most importantly enjoy themselves for a moment in the landscape.

MEMORY Each place has a unique history which is expressed through the architecture. In some sites where no physical evidence of cultural activity remains, the architectural interventions narrate the story. These attractions contribute to the national identity of Norway and form a relationship between the visitors and the landscape.

REHABILITATION By providing specific infrastructure on which the visitor may inhabit, the terrain and landscape features are protected from visitor traffic. The visitor to these places also experiences an intimacy with the landscape.

ACCESSIBILITY By providing accessible attractions along the national routes, visitors can experience the once isolated features of the landscape. In addition to providing accessibility, the landscapes are experienced in a new way through the careful design of architectural interventions.

${ }^{120}$ Turistveger, Nasjonale. "Architecture and art." Architecture and art - National Tourist Routes in Norway, Accessed March 03, 2017. http://www.nasjonaleturistveger.no/en/about-us/architecture-and-art. 
FIGURE 24 TOURIST ROUTE RONDANE Sohlbergplassen Viewpoint

by Carl-Viggo Hølmebakk Architects

The Sohlbergplassen the viewing point at Atnsjøen lake frames the view of the water as well as the rounded peaks of the Rondane. The platform appears to be shaped by the space around at as it gently curves around the pine trees, yet separates itself from its surrounding by hovering over the landscape. As quoted by the National Tourist Routes, "...the rounded peaks of the Rondane massif almost exactly as they appear in Harald Sohlberg's famous painting "Winter's Night in Rondane" ("' (Photo: Tonje Tjernet).

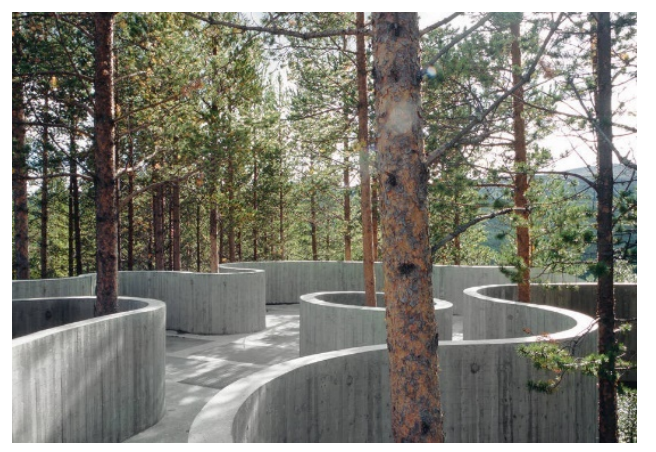

FIGURE 25 TOURIST ROUTE RONDANE Aurland Lookout by Architects Todd Saunders And Tommie Wilhelmsen

The viewing platform reaches 30 metres out from the road, over a forest of pine trees, and 650 metres above the fjord below. The glass rail at the end of the lookout gives the illusion that space disappears in to the fjord landscape beyond. (Photo: Tonje Tjernet).

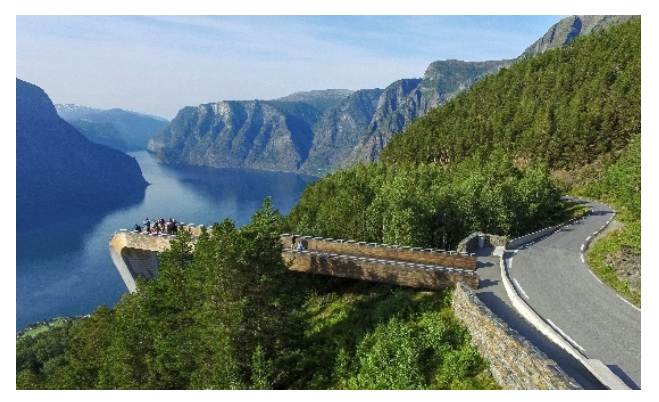

FIGURE 26 TOURIST ROUTE SENJA Tungeneset Rest Area

by Code Arkitektur

The Tungeneset rest area is located on a point of a land that juts out into a water body separating two fjords. The materiality of the walkway responds to the vernacular of its surrounding and follows the rocky terrain below. The walkway leads to a view of the sharp Okshornan peaks in the distance (Photo: Jarle Wæhler).

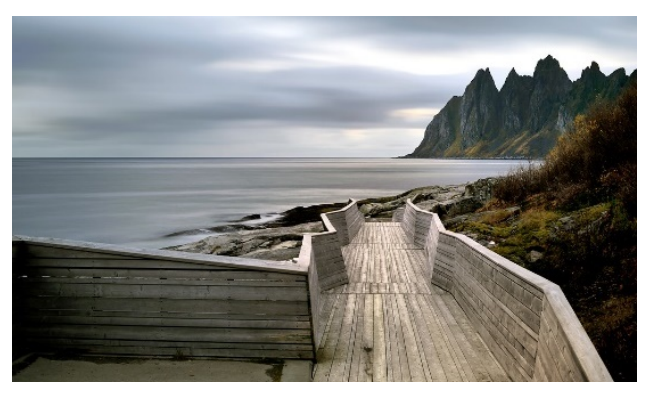




\section{Part Four}

DESIGN PROPOSAL

4.1 Program

4.2 Site Plan

4.3 The Memories 4.2 


\subsection{Program Development}

\section{THE PROBLEM}

As can be concluded from the research of the previous chapters, pedestrian life around the Research Fields of the Farm is uncomfortable and inaccessible. Unlike the Arbouretum and campus-like core of the Farm, the Research Fields were not designed for the leisurely enjoyment of pedestrians. Many people use the Farm each day to commute, walk, bike, or run, but seasonal conditions such as intense sun in summer, flooding in spring, strong winds in fall, and snow in winter limit these activities as well as contribute to the general feeling of uncomfortableness in the vast landscape of the research fields. In addition, there are several forces which are compromising the future of the Farm and include: salt contamination on Carling Avenue, contamination of Sir John Carling site, lack of centrality, lack of a strong identity, and the lack of clear entry points.

\section{PROGRAM}

To address the problem stated above, this thesis proposes a network of scenic pedestrian pathways, to work in conjunction and enhance the existing pedestrian experience throughout the Farm. The program pays tribute to the citywide parkway network established in the mid-20th century. The parkways were implemented by planners seeking to "beautify" the industrial city and provide uninterrupted processions connecting Federal Sites. A consequence of the parkway network was the pedestrian pathway network which often follows the parkways throughout the city. Prince of Wales Drives, which provides an uninterrupted procession from Parliament Hill to the Farm, and is bordered by some of the most scenic pedestrian pathways in the city. The picturesque arrival to the Farm, which becomes unclear once arriving at the Farm, and does not extend beyond the core, is to be established in through the design of pathways at the scale of the pedestrian. Like the parkway system, the pedestrian pathways are not meant to replace the primary transportation routes throughout the site, but offer a unifying planning gesture to the Farm and foster connection between users of the site and the landscape.

\section{NARRATIVE}

The narrative of the proposed pathways is meant to tell a story in which one can find their own connection. By framing the story in eight simple and familiar terms: the clearing, the grave, the forest, the meadow, the passage, the river, the shelterbelt, and the swamp, a venue in which the landscape can be interpreted is proposed. Through the process of journeying through the landscape under the guidance of a designed procession, seeks to evoke thoughts and connections to the landscape at a 
personal level. From the eyes of the designed, the pathways represent the memories of the Farm landscape, the memories of the agricultural history of Canada, as well as the people who inhabited the landscape before Canada, however perhaps more important than understanding a factual history of agriculture, but rather the understanding and intimate connection to the landscape formed on the journey through the landscape. The proposal will employ Cornelius Holtorf's definition of cultural memory as not reconstructing the past accurately and truthful, but making meaningful statements about the past in the present context. The meaningful statements, or the memories, are a series of nodes, entry points, or areas of interest along the pedestrian pathways which cause occupants to stop, see, hear, or think differently about the landscape they are passing through.

\section{DESIGN STRATEGY}

In line with the Picturesque planning techniques applied to the Arbouretum and core of the Farm, similar planning will be applied to the Research Fields in three ways. At the large scale, the pathways extend from existing pathways around the border and forms new entry points around the periphery. The entry nodes will represent the composition of elements and of patterns in the existing landscape. In the immediate scale of the pathway and shelterbelt, a variety of a variety of seasonal materials and textures offer interest in the immediate, yet work together in the larger composition of the Farm. Finally, the picturesque was historically employed as a process of revealing elements in the landscape in a highly controlled, yet seemingly effortless manner to reveal elements in the landscape in a highly controlled, yet effortless manner to show vistas and points of interest. This design will employ a process of revealing through combining existing vegetation with new as well as the placement of points of interest and rest stop. 


\subsection{Site Plan}

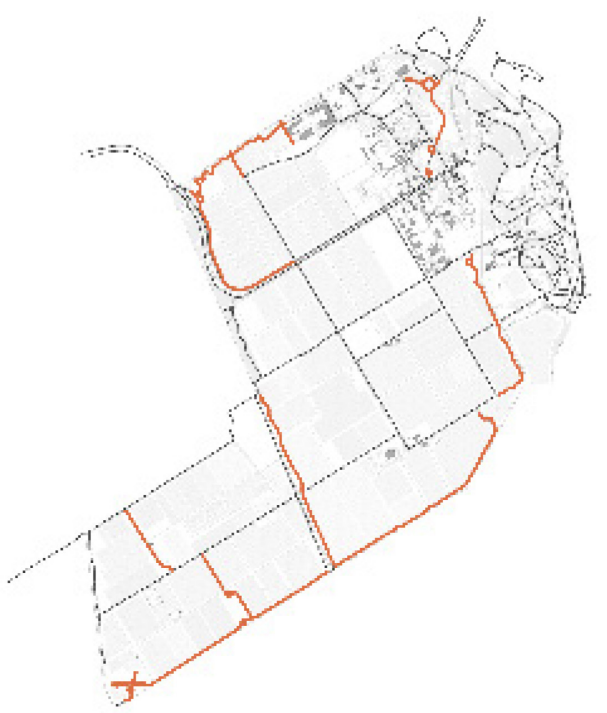

public pathways

$=\rightarrow$

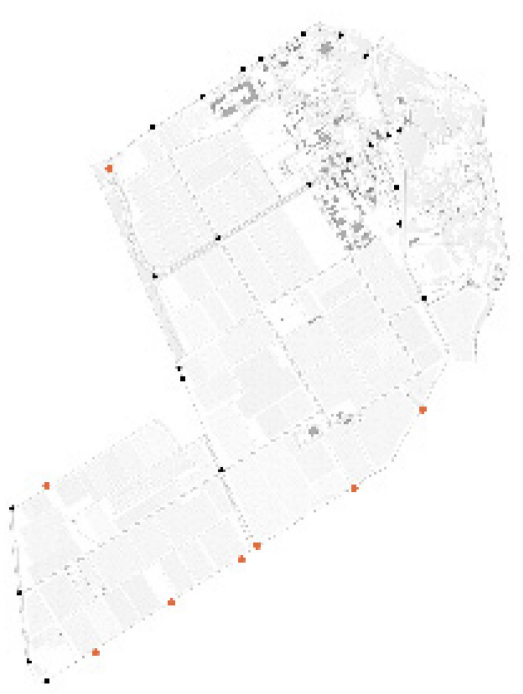

public entry points

: : : : : :

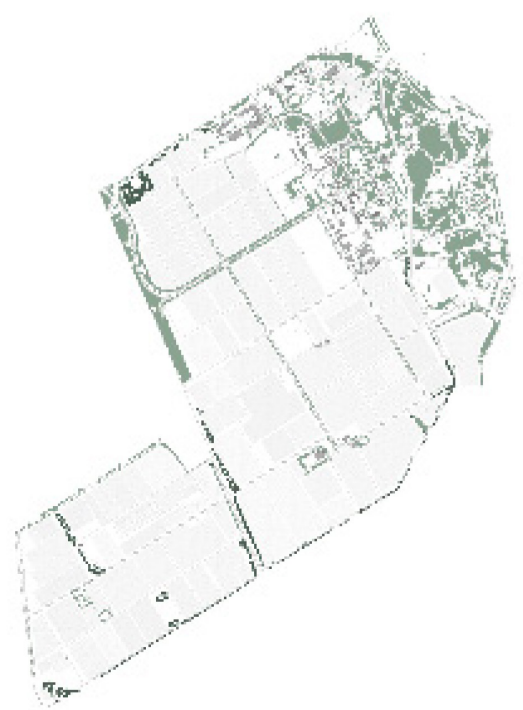

vegetation

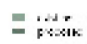

| FIGURE 1

Diagrammatic site plan. 


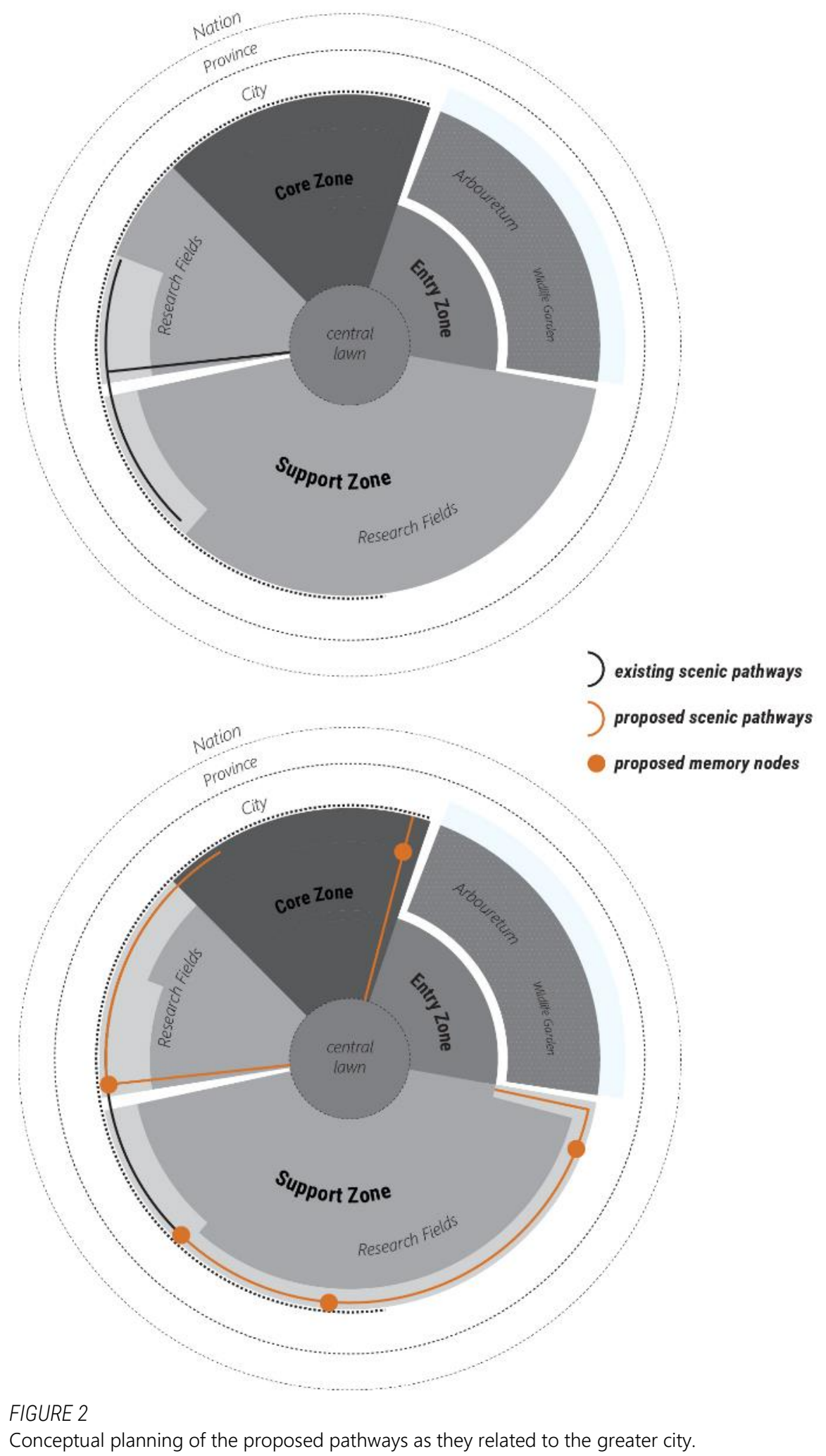




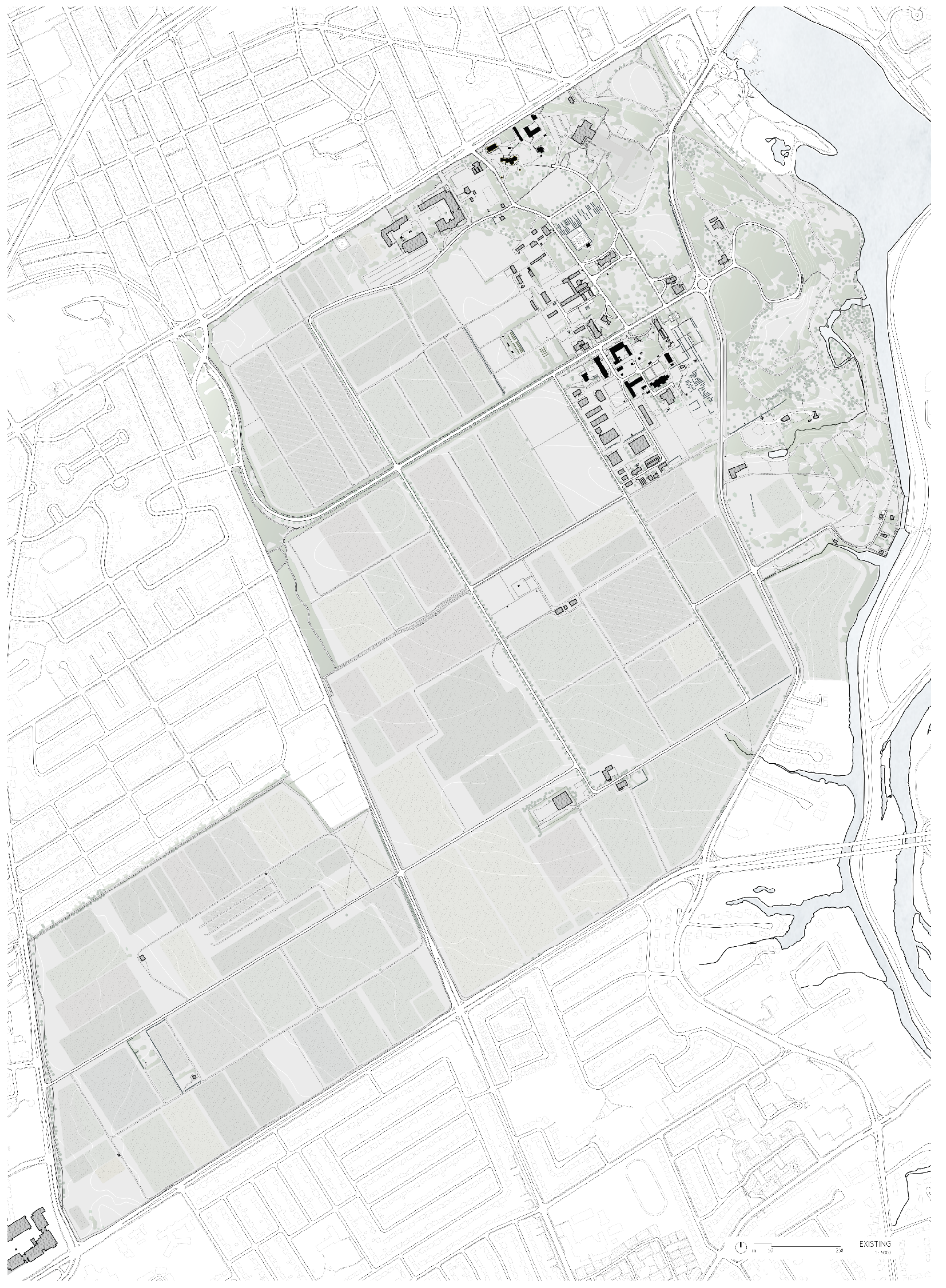




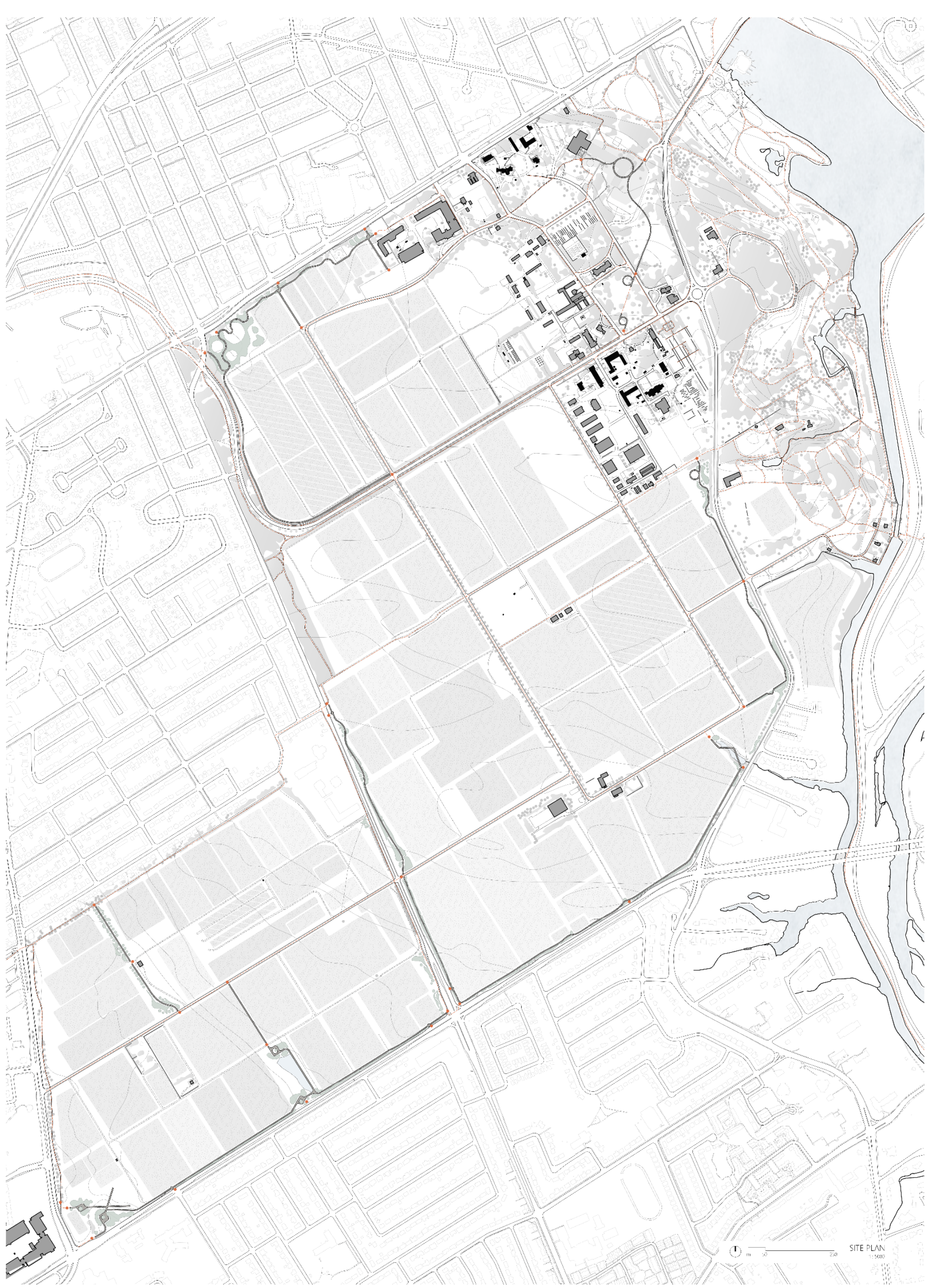




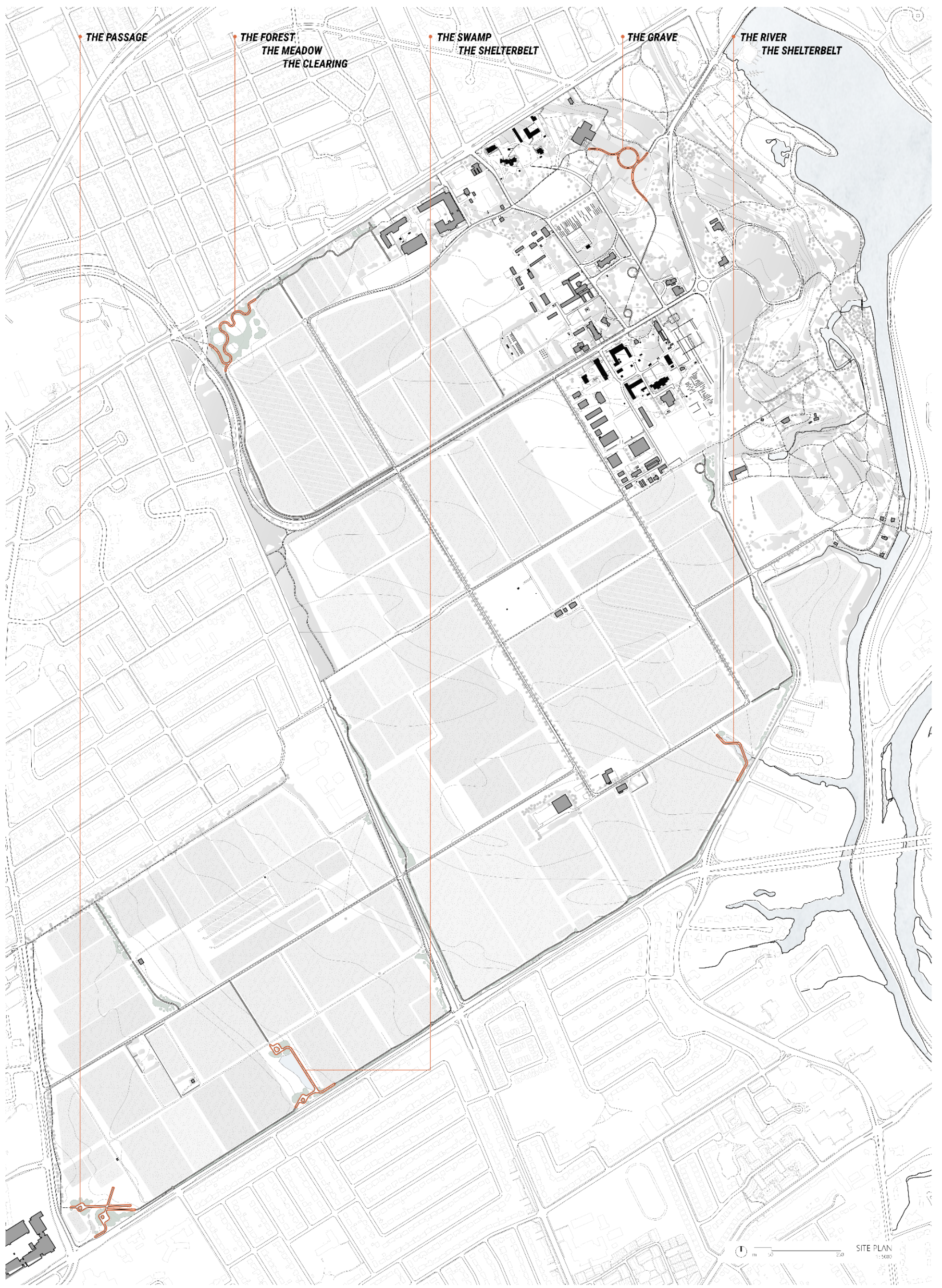




\section{The Passage}

\section{DESCRIPTION}

The Passage, located at the corner of Merivale and Baseline Road provides a gateway to the southwest corner of the site connecting the recently inhabited Agriculture and Agri-food Canada buildings with the Research Fields of the Farm. A new pathway on the west side connects the maturing Merivale Shelterbelt pathway to the gateway. A new pathway on the south side formally designates entrance to the Farm from Baseline Road. The fence line which designates the border of the Farm is pushed back from the road line and follows the undulating edge of the raised wooden boardwalk.

\section{MEMORY}

The notion of Passage recalls the seasonal movement of the first inhabitants throughout the land. Developed over hundreds of years, a network of pathways cut through the primeval forest and other dense terrain to allow movement of peoples throughout the Ottawa region. When the first European colonisers began to occupy the land and set up their homesteads, land was chosen for its proximity to these clear pathways. The first generation of settlers utilised these cleared pathways, however new growth over the subsequent generations would make evident the diminishment of Aboriginal peoples in the Ottawa region and the occupation by European settlers.

\section{PROCESSION}

From the intersection of Merivale Road and Baseline Road, the viewscape into the Farm is framed by two converging raised boardwalks flanked by a variety of seasonal vegetation. The pattern of Research Field, groupings of tress and urban structures form the skyline beyond. Entering onto the pathway from the Baseline Road sidewalk the viewscape beyond is hinted through the spaces in the vegetation. Continuing northeast along the pathway the pedestrian arrives at a sheltered rest point receiving protection from the strong sun and wind common on this area of the Farm. Disappearing further into the pathway the busy roadway and urban surrounding becomes more distant. The space around the pedestrian brings forth the variety of seasonal colours and textures as backdrop to the wooden pathway and railings of the boardwalk. Passing through the rest point the first compete vista of the Farm is revealed to the pedestrian with the southeastern part of the site almost visible in its entirety. Venturing out onto the rectilinear extension, the pedestrian is removed from the shelter of the vegetation, and exists as one between the sky above and blowing rows of crops below.

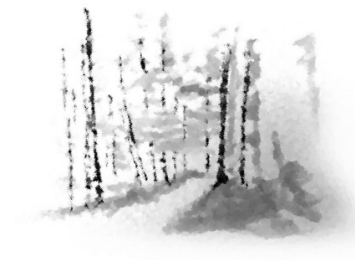

FIGURE 3

The Passage. 


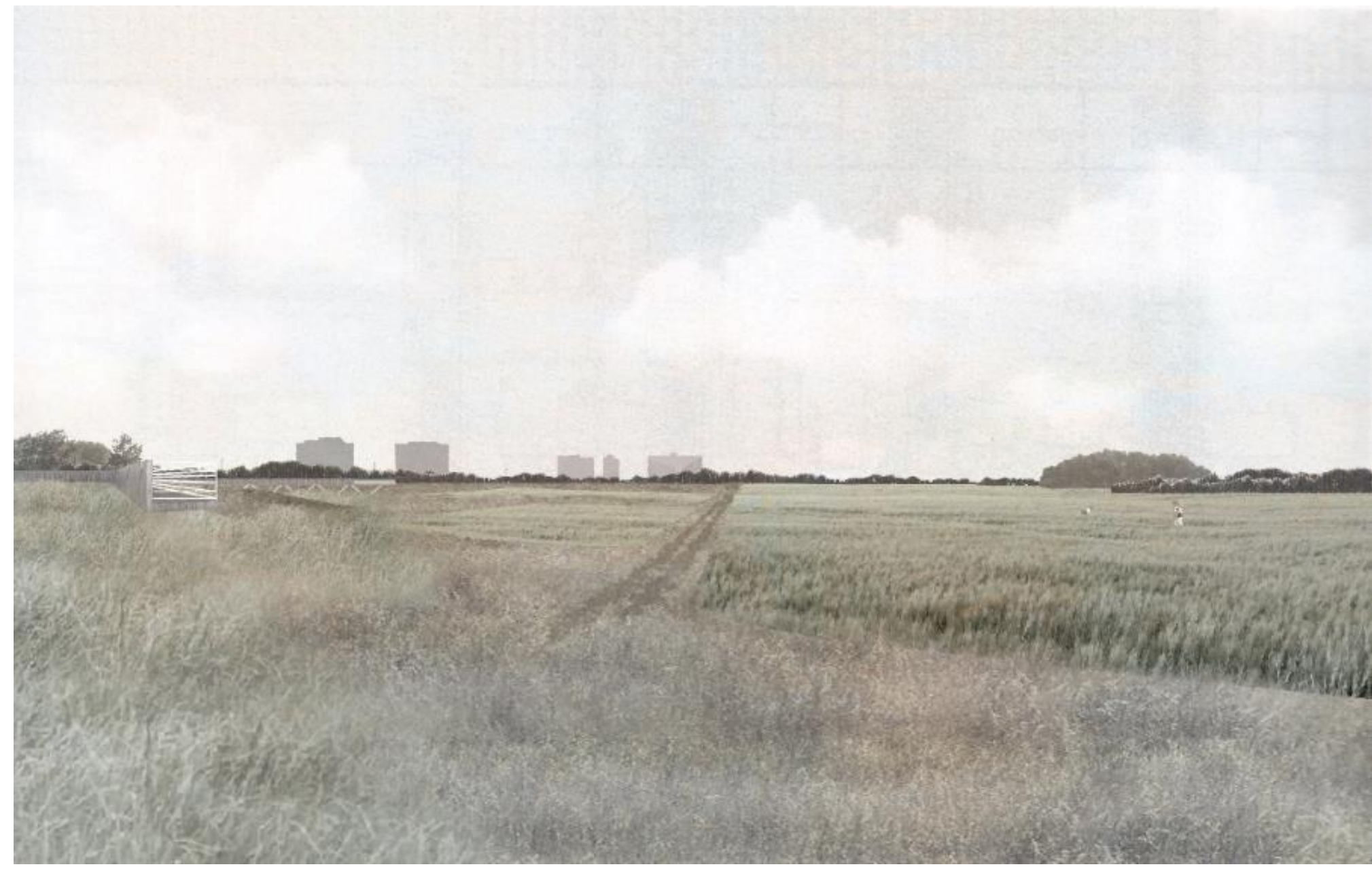

FIGURE 4

Perspective from south edge of the site. 


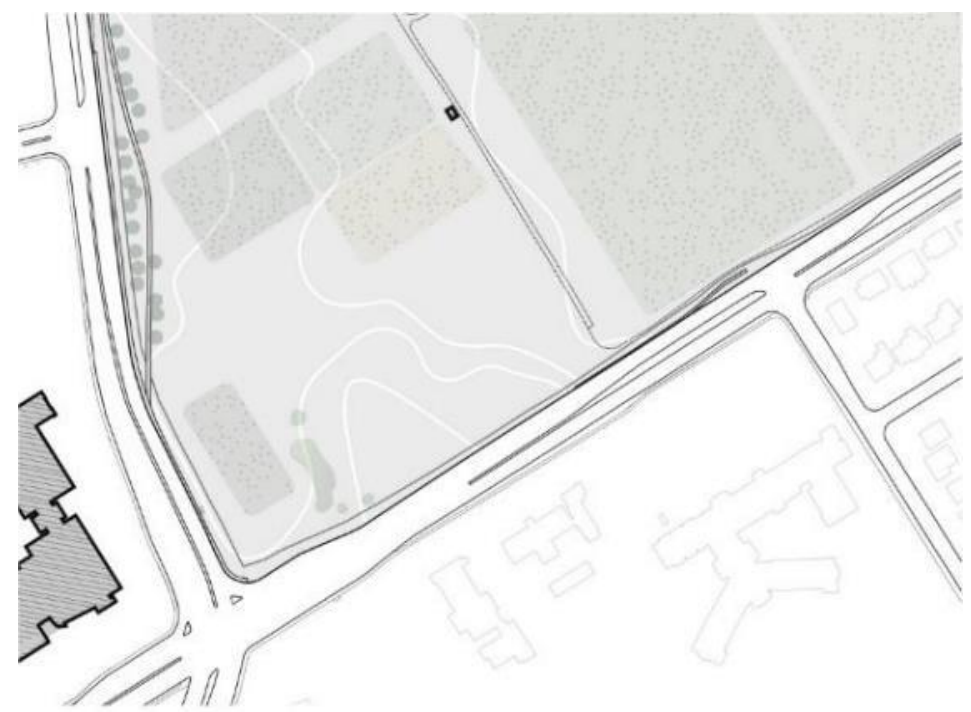

FIGURE 5

Top: Existing Conditions, Middle:

Proposed Memory, Bottom:

Proposed Pathways.
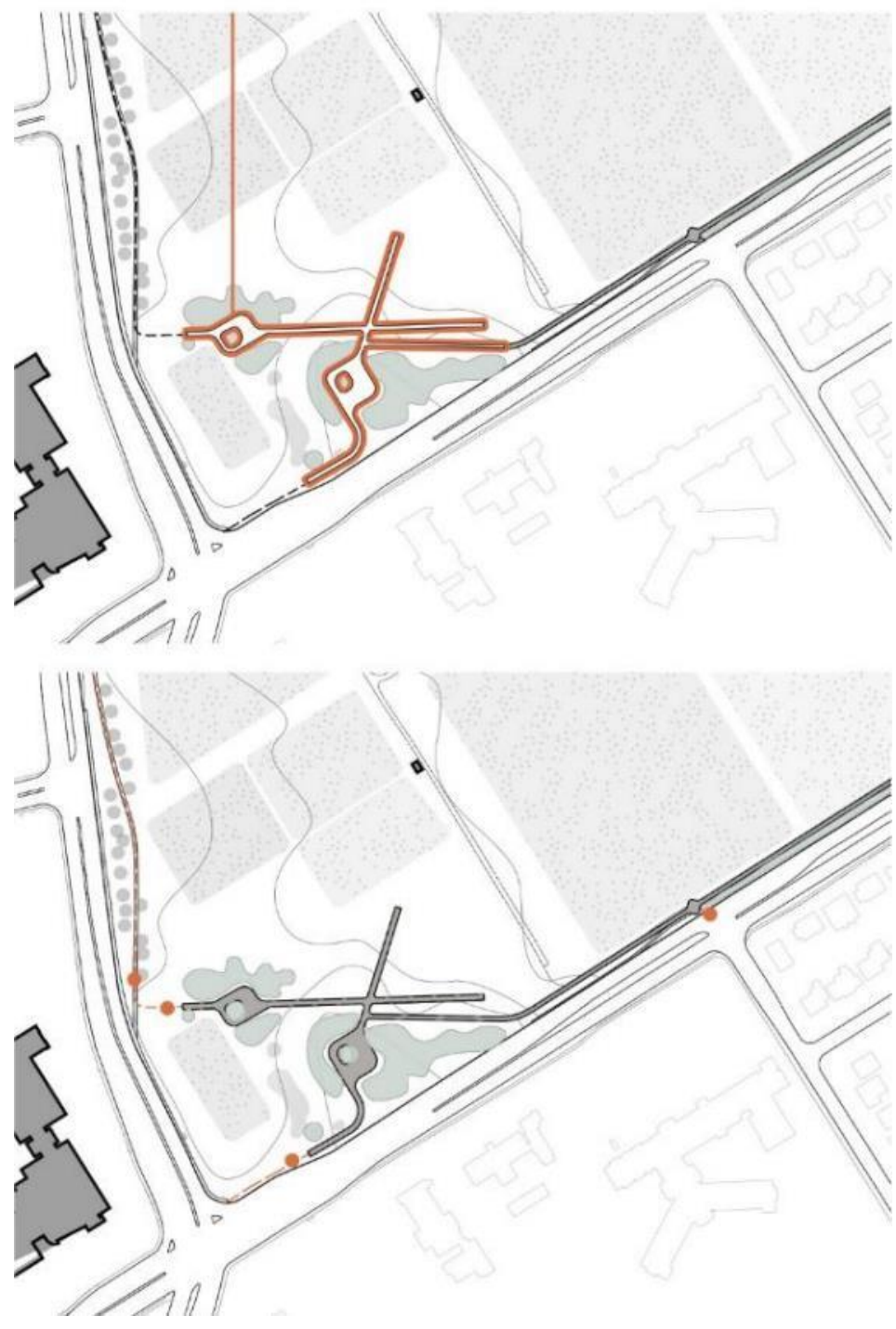


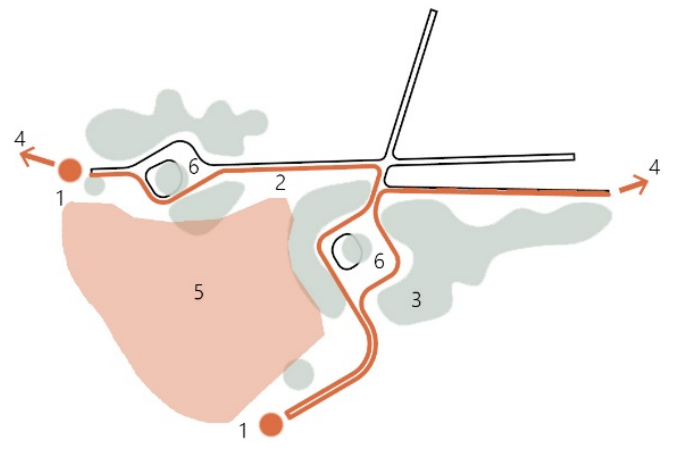

forces

1 pedestrian entry points

2 fence edge

protection from salt spray

4 connection to pathway network

5 Merivale / Baseline gateway

6 pedestrian rest spots
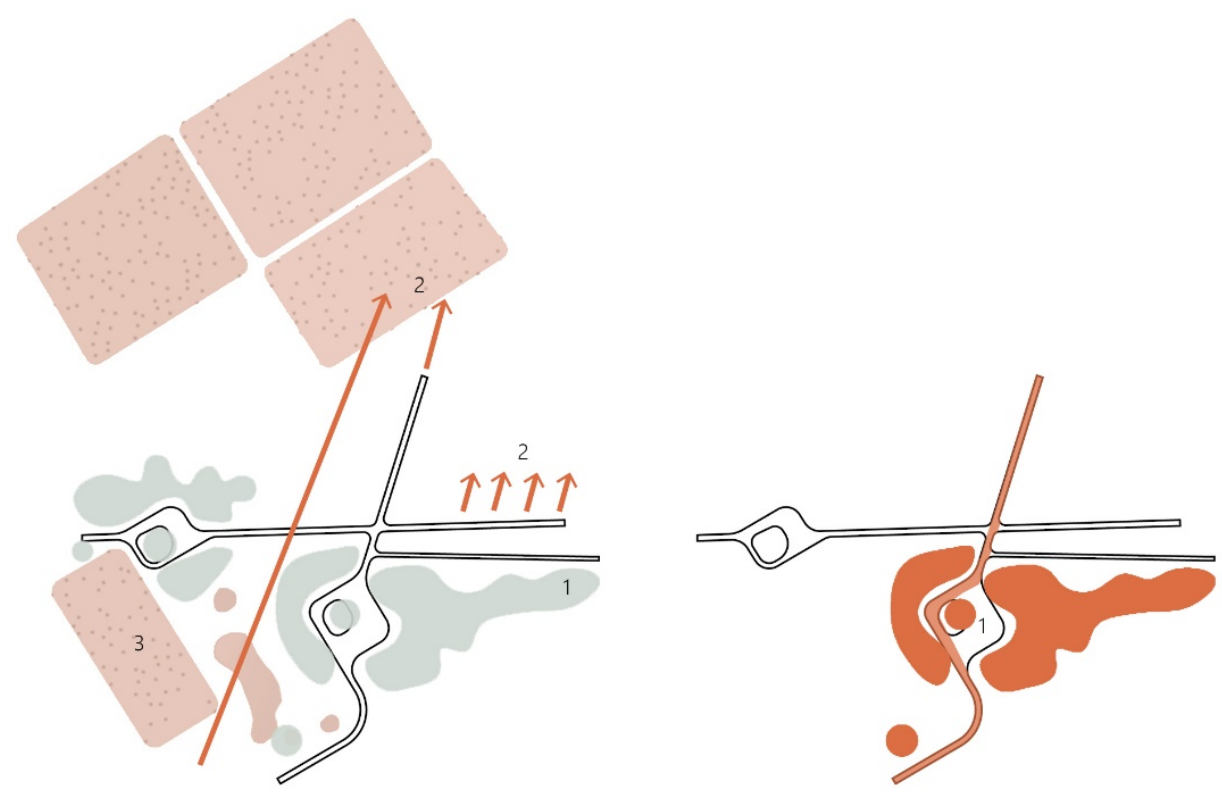

\section{defining characteristics}

1 shelterbelts

2 viewscapes

3 variety of seasonal textures memory

1 passage 


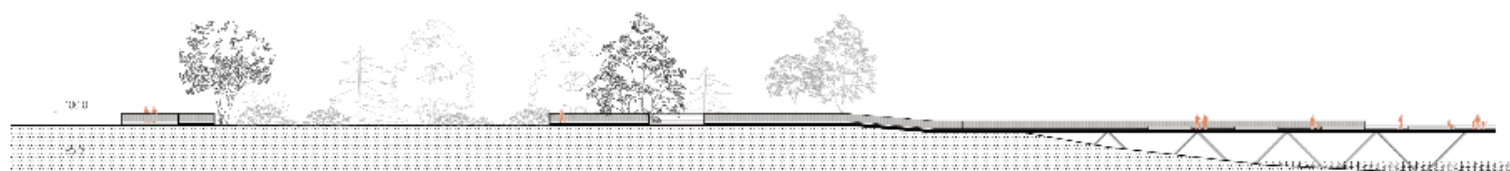

$5 L C 1 O N B$
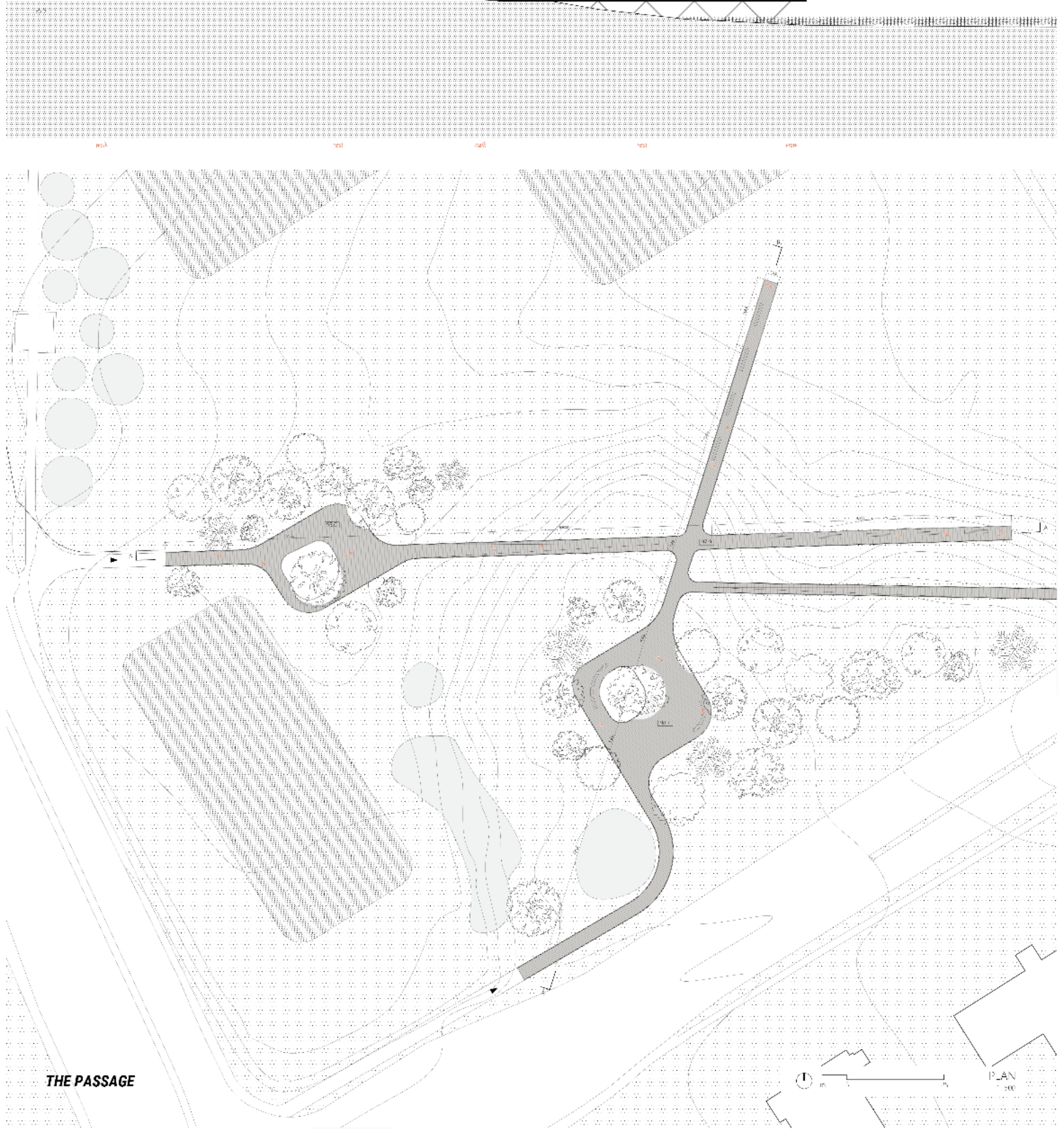


\section{The Clearing, the Meadow, and the Forest}

\section{DESCRIPTION}

The Clearing, the Meadow, and the Forest are located at the corner of Carling Avenue and Fisher Ave. In response to the contamination of the soil caused by the salt of the adjacent roadway, a "third growth" forest is proposed to slow the contamination from passing further in to the site and to protect the historic Plot \#1. The proposed raised boardwalk respond to the unmarked trails created by pedestrians wishing to gain entry to the site from these points. The fence line is replaced by the rail of the undulating boardwalk to welcome entrance into the Farm, however maintain the secure edge of the place of scientific research.

\section{MEMORY}

The notion of Forest recalls the primeval vegetation which covered much of the Ottawa Region during its beginnings, and the subsequent second growth forests planted to replace the diminishment by the lumber industry of European settlers. The Carling-Fisher corner specifically recalls the shelterbelt of Dutch Elm which was removed in response to invasive species in the mid-20 th century. The notion of Meadow recalls the hunting techniques used by Aboriginal peoples to improve grazing and attract specific animals to these places to hunt. The Clearing recalls the notion of homestead used by early European settlers in which an area of forest was cleared to practice subsistent farming. The contrasting notion of Meadow and Clearing show the opposing ideologies of the First Nations and the first European settlers. The First Nations demonstrate a sensitive and sustainable relationship with their practices where the Europeans stand in opposition to the land, cutting out resources from the landscape.

\section{PROCESSION}

Entering onto the pathway from the Carling-Fisher corner, the pedestrian travels along the raised boardwalk and is surrounded by vegetation on both sides. As the undulating path weaves through the forest the sun filled Meadow is visible in the distance from the secluded boardwalk. The pedestrian can observe the activity of the Meadow while staying hidden in the Forest. Continuing further along the boardwalk the pedestrian enters the Clearing. In contrast to the Meadow, where the pedestrian is the viewer hidden amongst the foliage and looks into the opening, the pedestrian becomes the object in the opening, exposed on all sides to the surrounding forest. Once protected, cool, and still amongst the foliage, as one enters the Clearing, the sun and wind appear again.
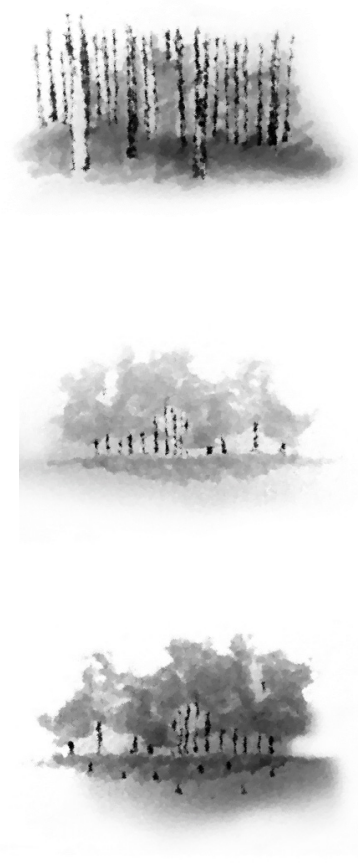

FIGURE 6

The Forest, the Meadow, and the Clearing. 


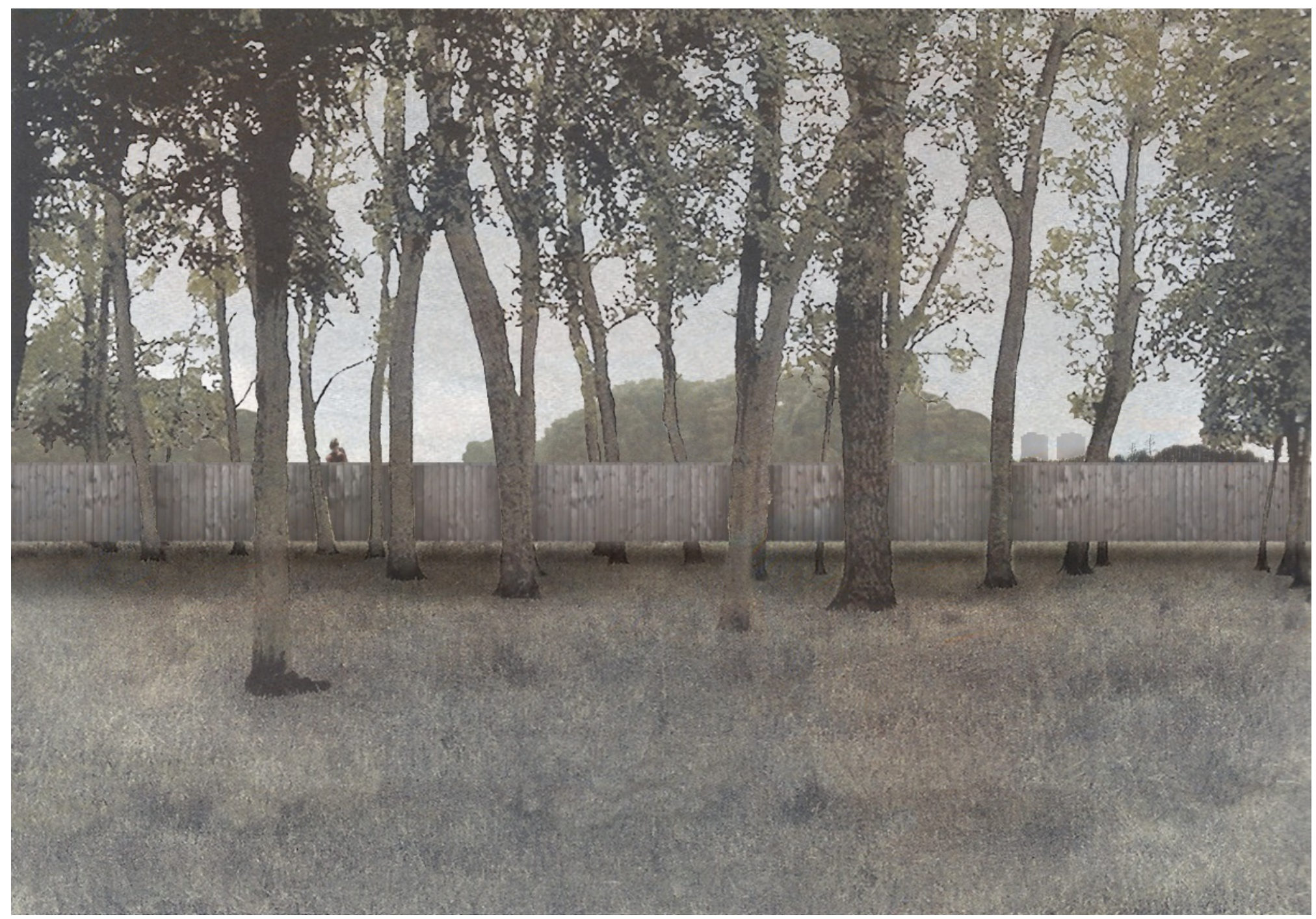

| FIGURE 7

Perspective from north edge of the site. 


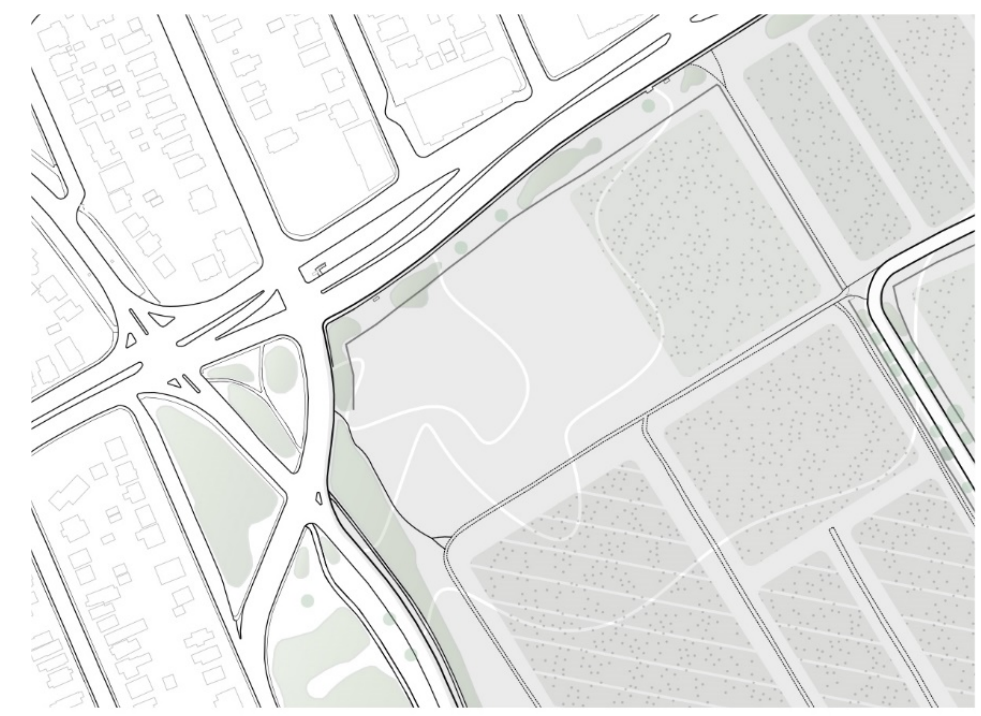

FIGURE 8

Top: Existing Conditions, Middle:

Proposed Memory, Bottom:

Proposed Pathways.
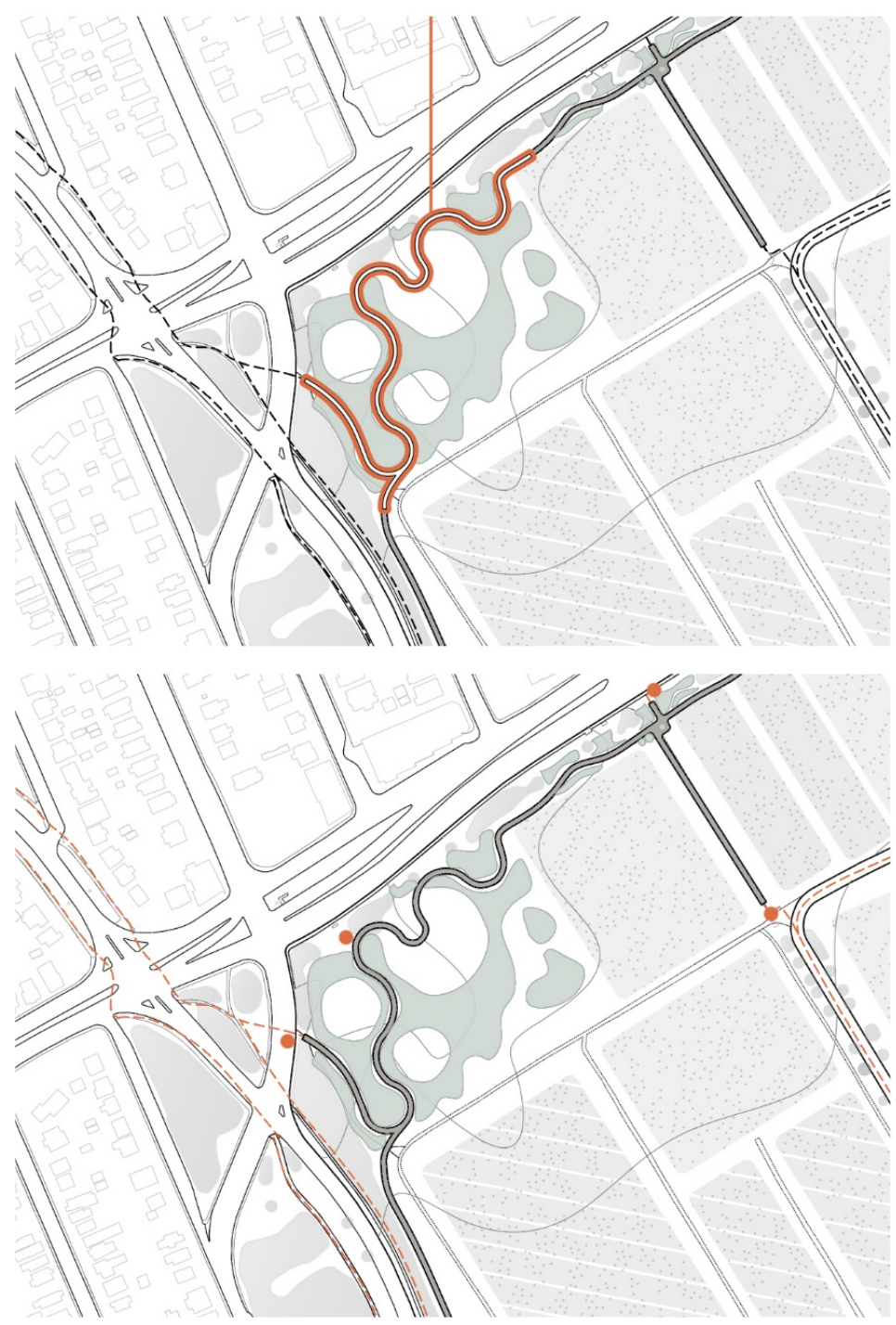


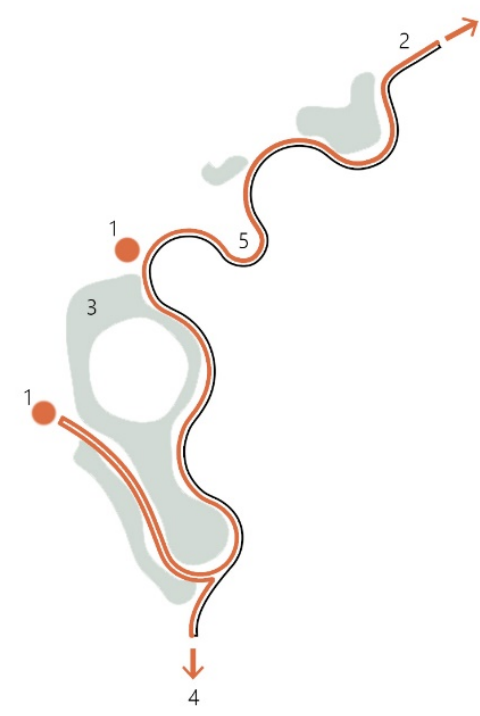

forces

1 pedestrian entry points

2 fence edge

3 protection from salt spray

4 connection to pathway network

5 pedestrian rest spots

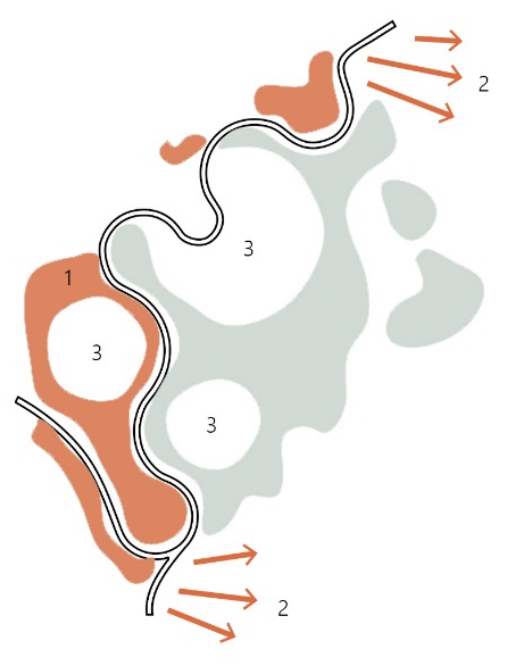

defining characteristics

1 shelterbelts

2 viewscapes

3 variety of seasonal textures

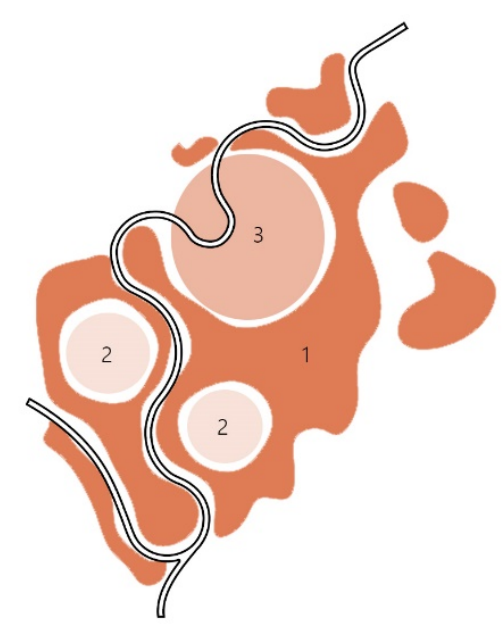

memory

1 forest

2 meadow

3 clearing 


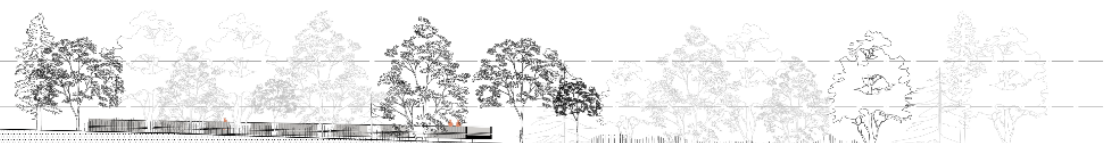

SLCIION B
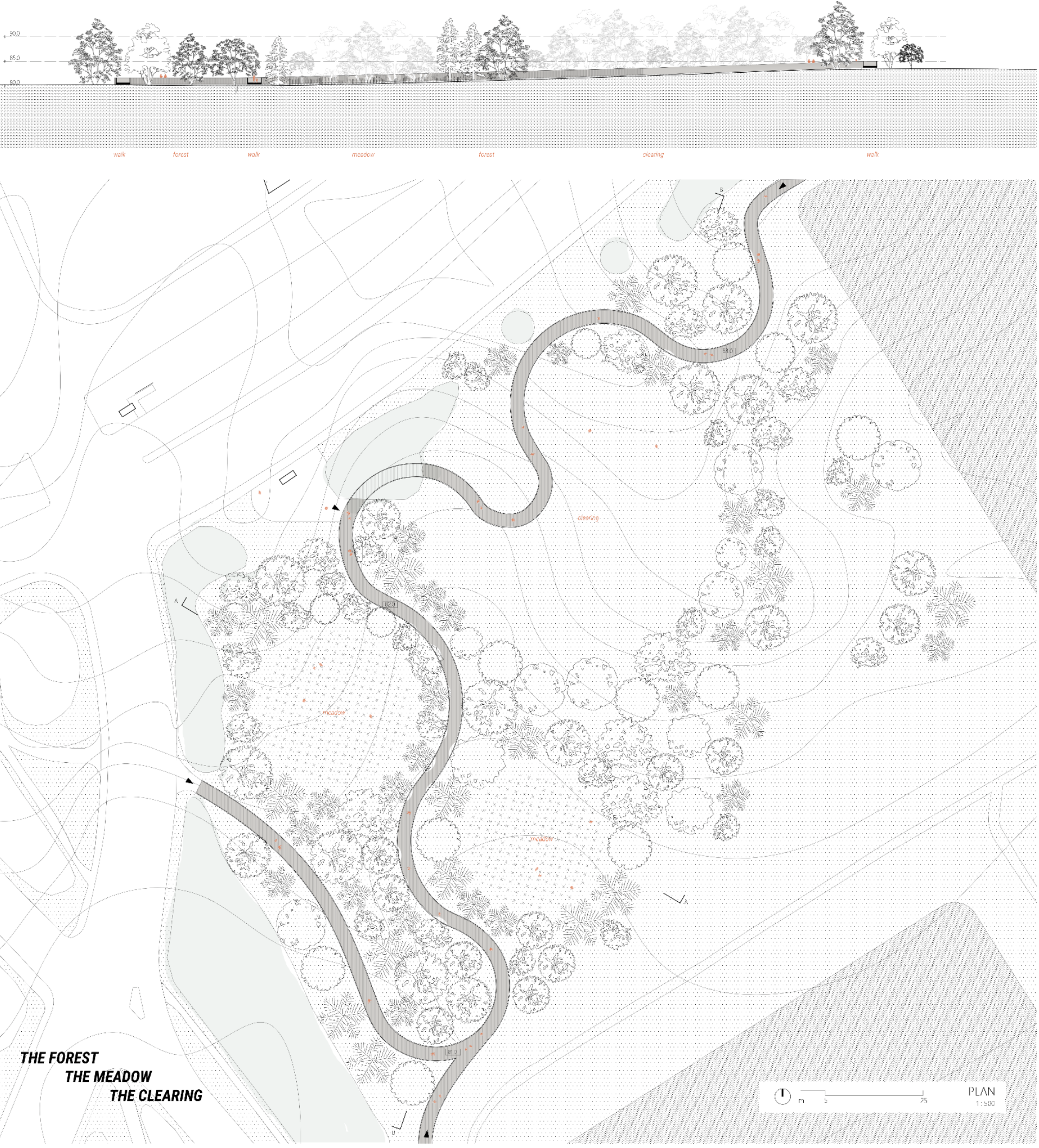


\section{The Swamp and the Shelterbelt}

\section{DESCRIPTION}

The Swamp and the Shelterbelt are located along Baseline Road mid-way between Merivale Road and Fisher Avenue. To address the shortage of water to the far west of the site for new plantings, a wetland is proposed to collect water. The Shelterbelt is proposed to provide protection from the sun and wind to pedestrians travelling along this open side of the Farm as well as to distinguish the edge between farm and city along this busy Transitway. Replacing the fence with the raised boardwalk also distinguishes the edge of the Farm, however created formal entrance into the Farm from the periphery.

\section{MEMORY}

The notion of Swamp recalls the landscape before the development of the Township of Nepean and City of Ottawa. The swampy landscape of the area made the development of the lands between Nepean and Ottawa challenging until the creation of the Rideau Canal and Dow's Lake which transformed the landscape. When the Farm's land was acquired it was comprised of many of acres of swampland which were transformed into the rolling landscape as it is seen today. The Shelterbelt, a key technique for the success of the agricultural industry in the late $19^{\text {th }}$ century, creates protection and stillness from along amongst the busy urban surrounding.

\section{PROCESSION}

Entering the raised boardwalk which runs along Baseline Road, the viewscape into the Farm is framed by the Shelterbelt. Entering onto the pedestrian rest spot the vista of the Farm is temporarily hidden and will be revealed again as the pedestrian moves east towards the crossing of the wetland. Moving out of the shelter of the vegetation, the pedestrian is surrounded on both sides by open Research Fields with vistas to the east and west, with the skyline of Shelterbelt plantings and urban structures in the skyline. The grouping of trees in the distance mark another pedestrian rest spot as one travels north further into the site. flanked by a variety of seasonal vegetation. The pattern of Research Field, groupings of tress and urban structures form the skyline beyond. Entering onto the pathway from the Baseline Road sidewalk the viewscape beyond is hinted through the spaces in the vegetation. Continuing northeast along the pathway the pedestrian arrives at a sheltered rest point receiving protection from the strong sun and wind common on this area of the Farm. Disappearing further into the pathway
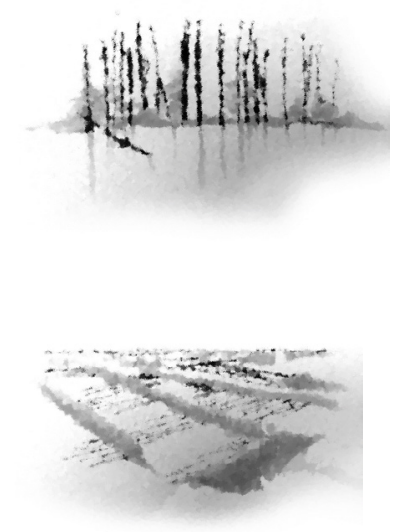

FIGURE 9

The Swamp and the Shelterbelt. 


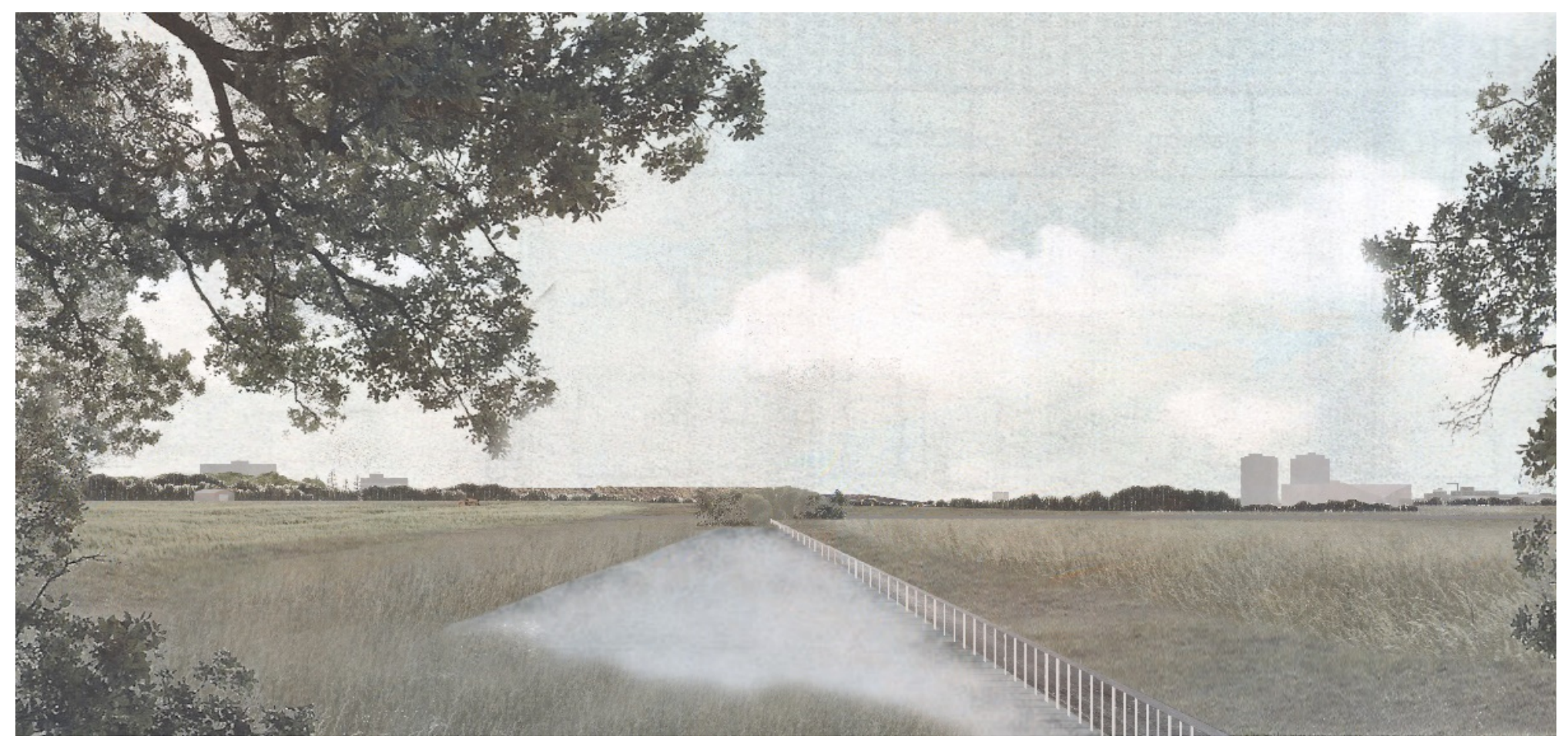

FIGURE 10

Perspective from north edge of the site with the faint Gatineau Hills in the background. 


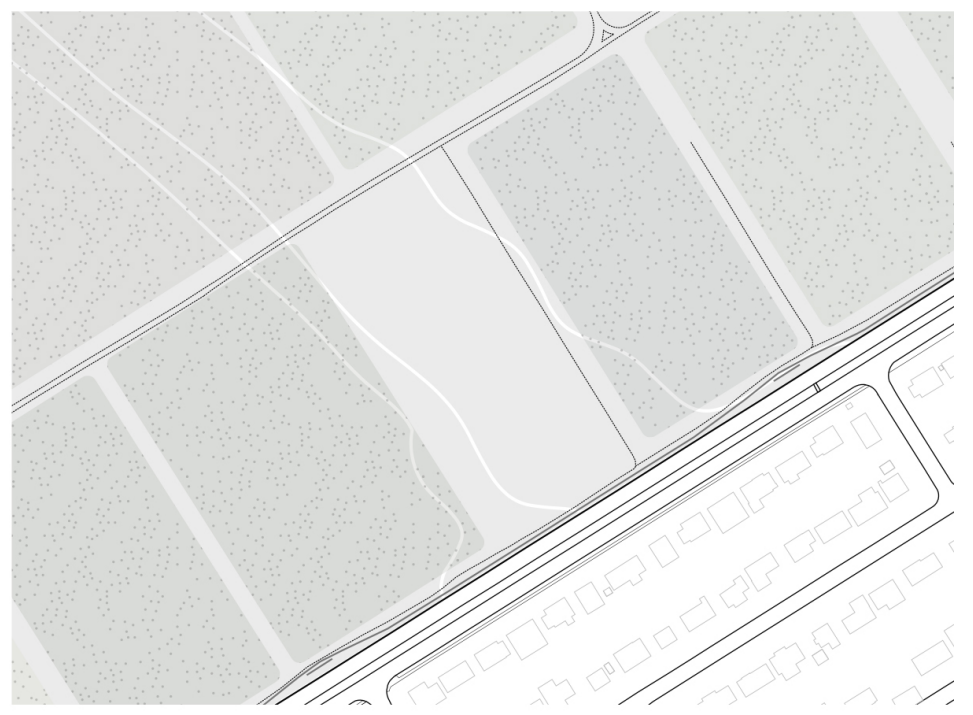

FIGURE 11

Top: Existing Conditions, Middle:

Proposed Memory, Bottom:

Proposed Pathways.
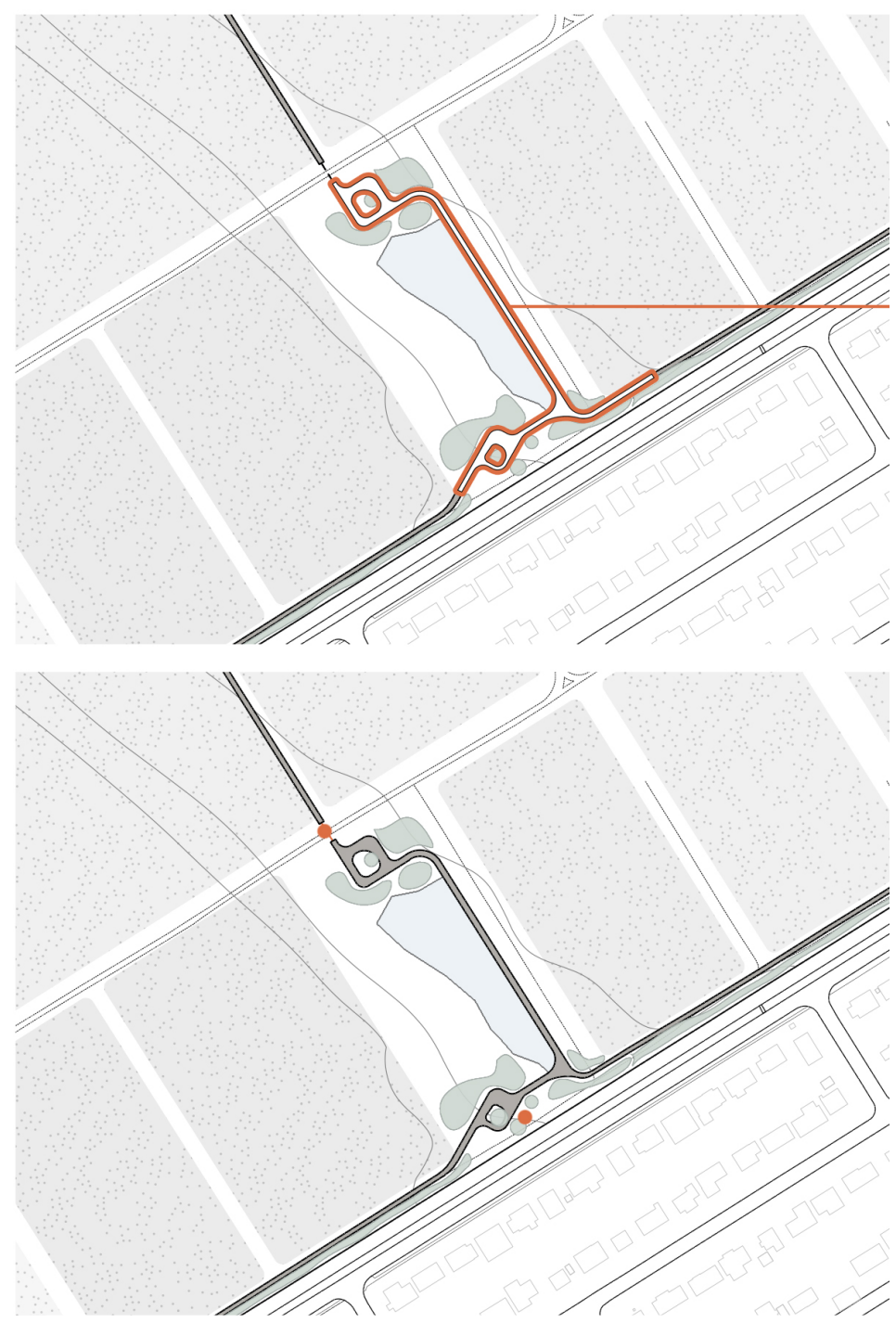


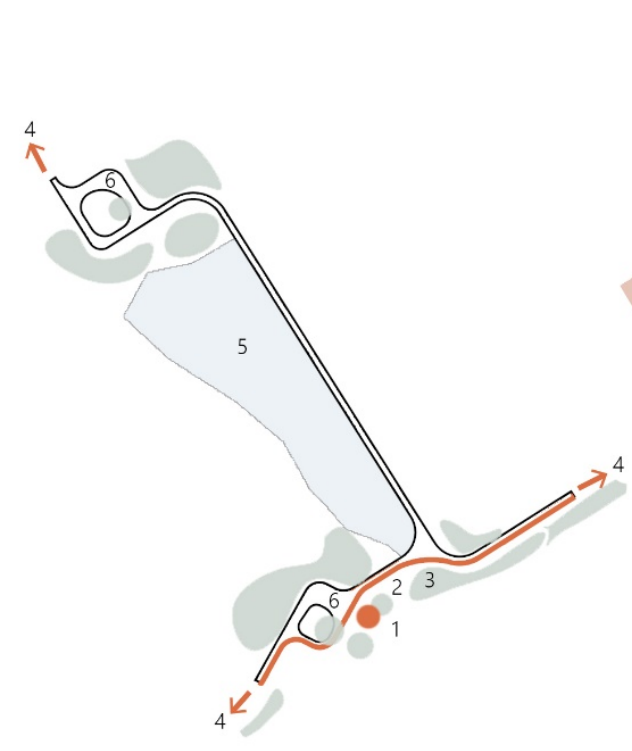

forces

\footnotetext{
pedestrian entry points

2 fence edge

3 protection from salt spray

4 connection to pathway network

5 water collection for new plantings

6 pedestrian rest spots
}

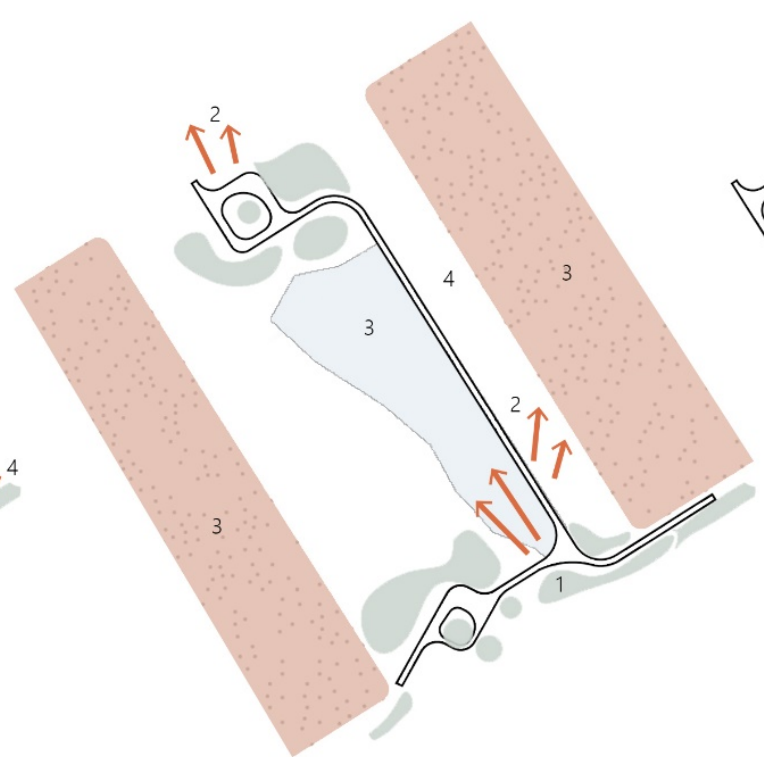

defining characteristics

1 shelterbelts

2 viewscapes

3 variety of seasonal textures

4 rectilinear planning of research fields

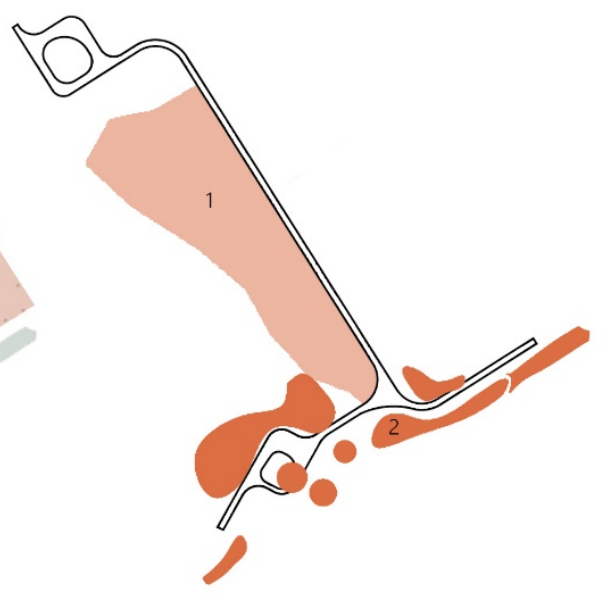

memory

1 swamp

2 shelterbelt 


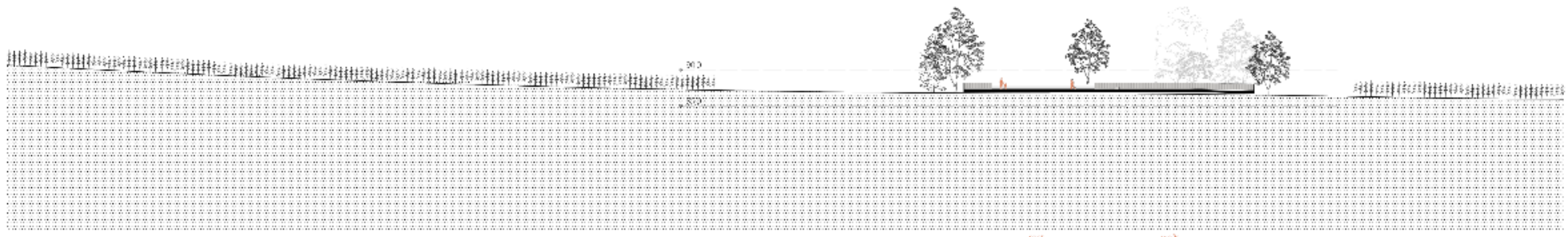

SLCIION 3
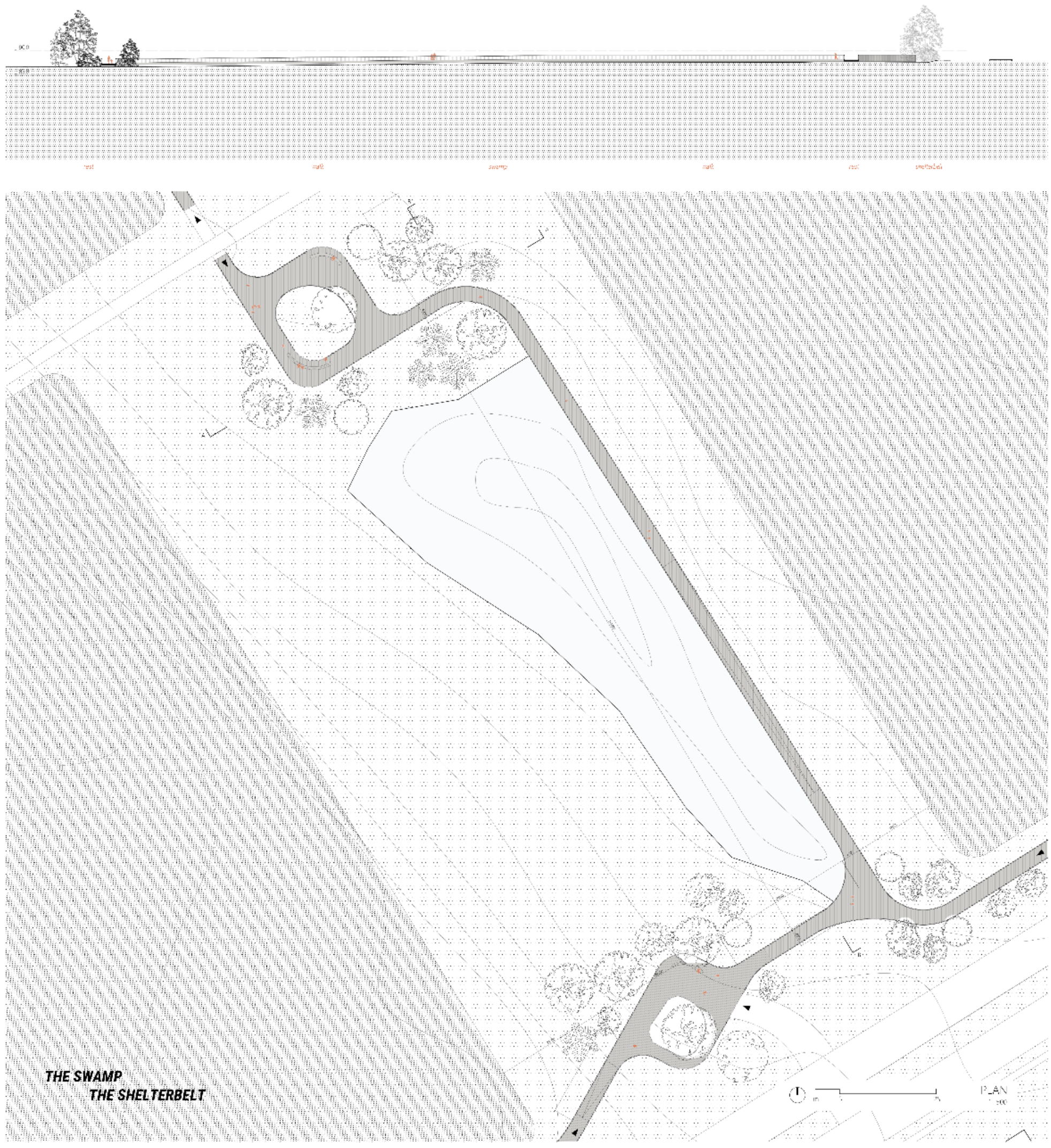


\section{The Grave}

\section{DESCRIPTION}

The Grave is located on the site of the demolished Sir John Carling Building. Contaminated by phenol due to the infilling of the demolished building with imploded concrete, the site stands abandoned and faces strong development pressure for the Civic Hospital expansion. The proposed Grave intends to mark the first step in recovering the landscape from the contamination to prepare the landscape for a future in line with the agricultural science identity of the Farm while providing pedestrian passage throughout the site. In response to the original planning of the site, the Grave restores the north-east entrance to the site. Entering from existing pedestrian pathways along Prince of Wales Drive, the Grave continues the uninterrupted procession from Parliament Hill to the Farm and arrived in a picturesque setting and provides viewscapes and vistas to the surrounding site and city.

\section{MEMORY}

The notion of Grave recalls the demolished Sir John Carling Building, a monumental mid-century office building home to the headquarters of AAFC, controversially demolished in 2014. The contaminated soil of the contaminated infill is removed to mark the first step in regeneration of the soil. In opposition to recreating the demolished building, or adding to the abandoned landscape, the removal of land speaks to the absence of the building. Through its absence reminding pedestrians of what previously existed.

\section{PROCESSION}

Entering onto the pathway from the historic north-east entrance to the Farm, the pedestrian moves along a circular boardwalk. The north-east procession is temporarily interrupted by the movement around and down into the excavated space. The viewscape to the surrounding city and site is replaced by the immediacy of the ground and sky as one descends into the Grave. Continuing along the circular pathway, and raising out of the lower pathway, the viewscape to the city and site is revealed again a the pedestrian continues north-east to the Central Lawn. 


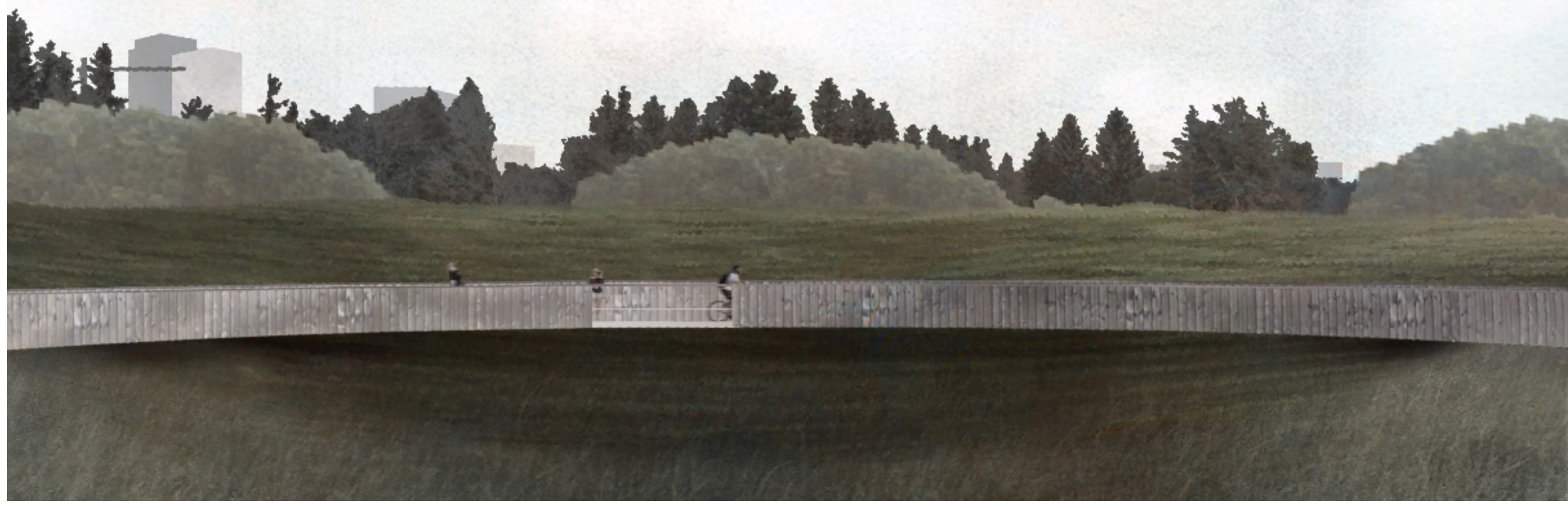

FIGURE 13

Perspective looking north-east towards downtown Ottawa. 


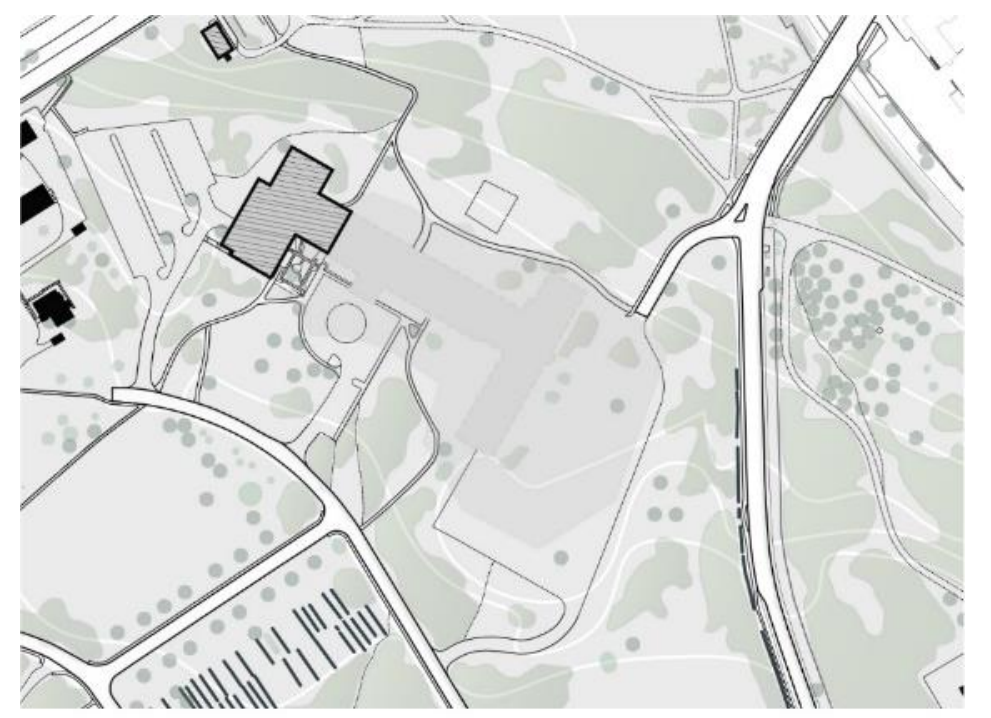

FIGURE 14

Top: Existing Conditions, Middle: Proposed Memory, Bottom: Proposed Pathways.
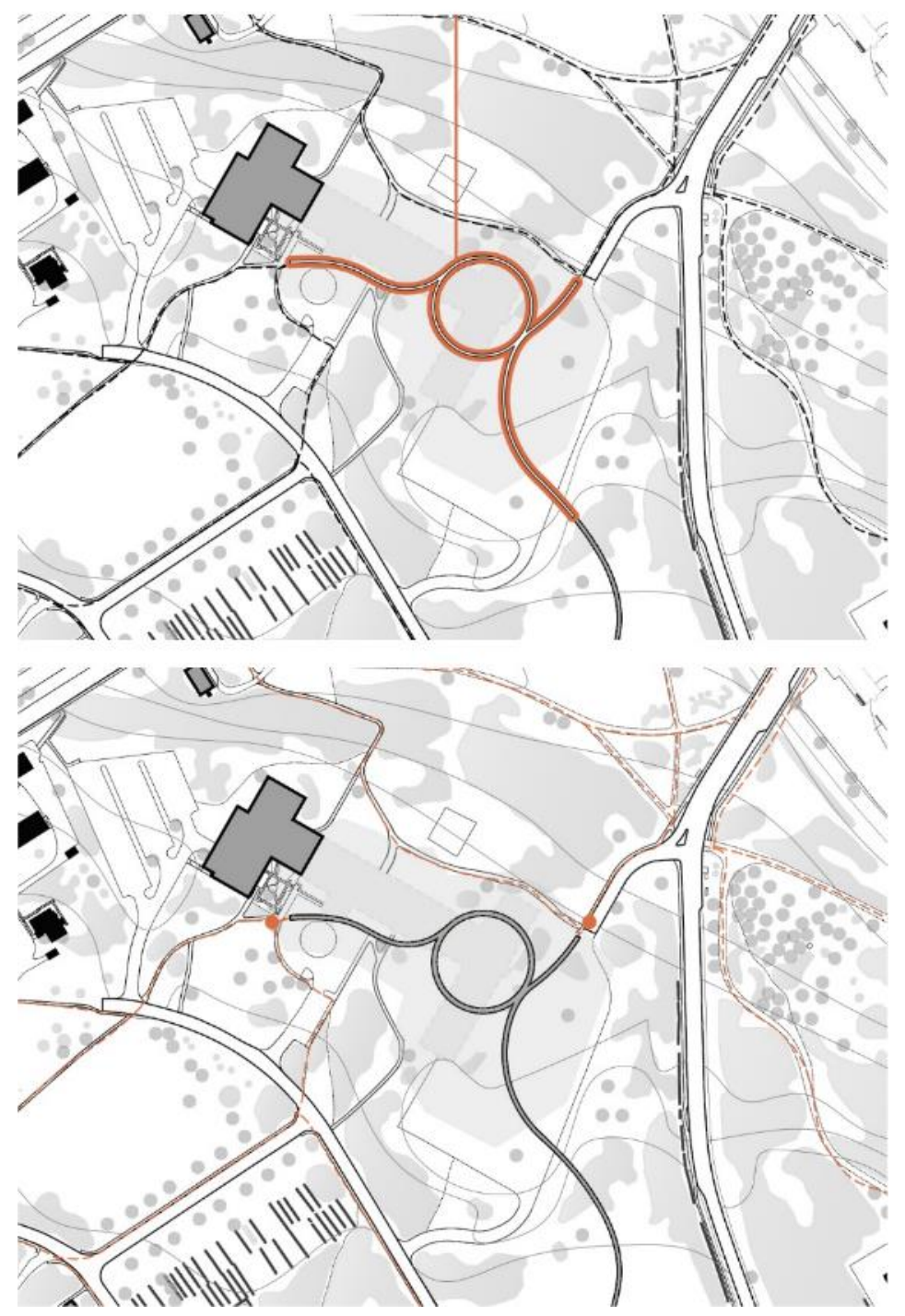


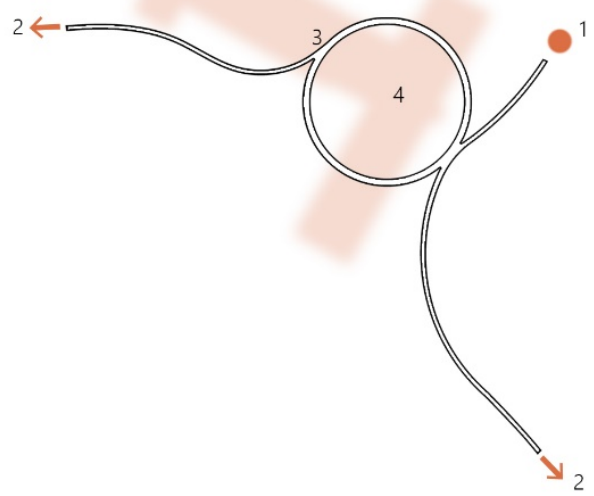

forces

pedestrian entry points

2 connection to pathway network

3 pedestrian rest spots

4 remediation of soil

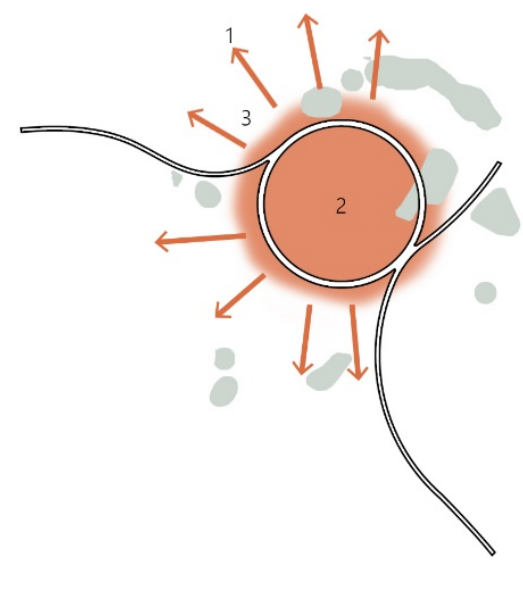

defining characteristics

1 viewscapes

2 variety of seasonal textures

3 honouring leaders in Canadian agriculture memory

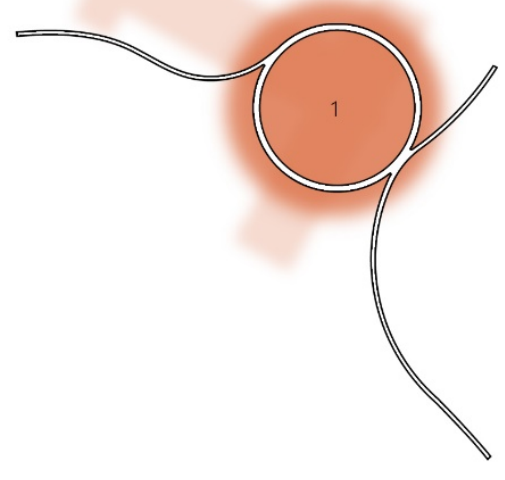

1 grave 

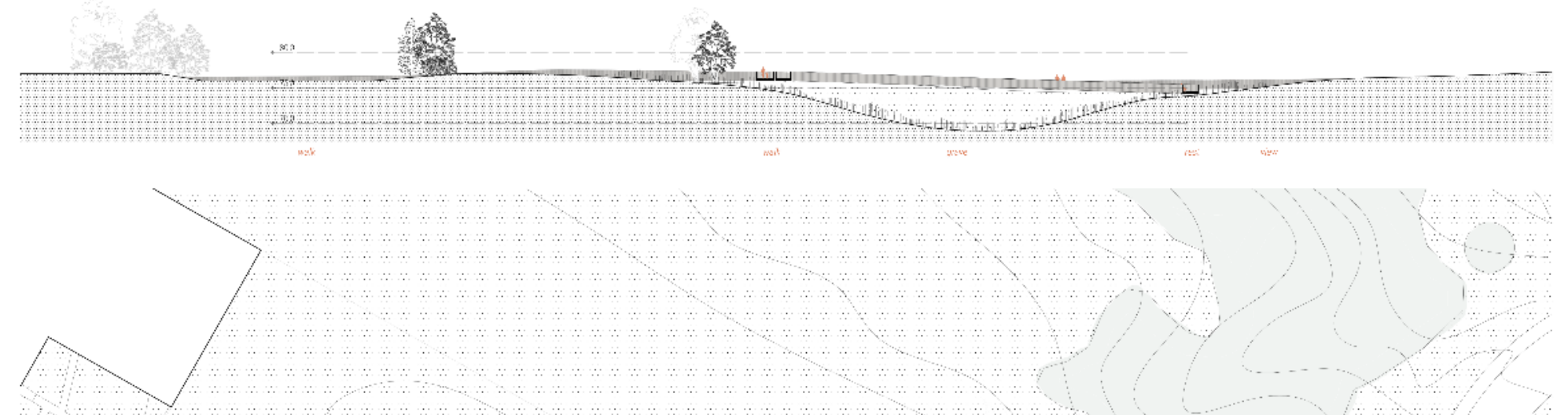

\section{(1)}

Q

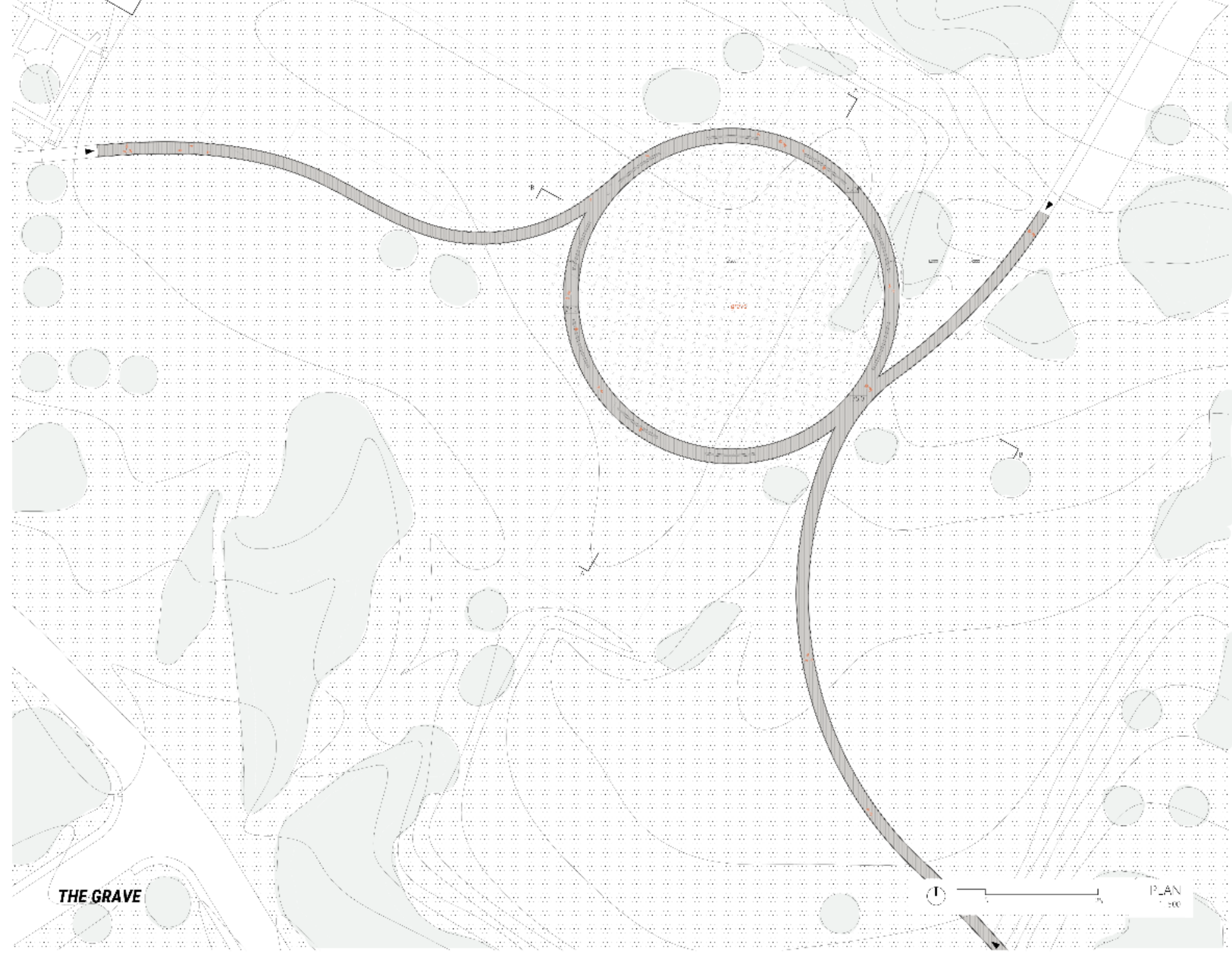




\section{The River and the Shelterbelt}

\section{DESCRIPTION}

The River and the Shelterbelt are located along Prince of Wales Drive and provide formal entrance to the site from the adjacent residential neighbourhood in response to existing trails and informal entrances. The pathway utilizes an existing stream and grouping of trees as an element in the procession of revealing the viewscape of planted trees along Morningside Drive. The edge of the boardwalk which defined the edge of the Farm ventures into the Farm from the periphery to and leaved the intact character pencil post fence as backdrop to the revealed viewscape. The boardwalk also moves in from the edge of the Farm to avoid the intense winds and traffic of the Prince of Wales bend.

\section{MEMORY}

The notion of River recalls the seasonal movement of the first inhabitants throughout the landscape. The waterway as the source of life and transportation throughout the Ottawa region. The River also recalls the distribution of the farmers of New France in the characteristic Seigneurial system. Long plots are distributed along a water corridor an extend back from the waterway. Due to the concentration of long slender plots to neighbouring plots, the homes of the farmers were close to each other fostering a close sense of community throughout the landscape. Throughout the larger site, this notion is marked by a resting point along the pathway (the River) and the extension of pathway perpendicular into the Farm.

\section{PROCESSION}

Moving along the pathway from the west the pedestrian enters the existing and new vegetation and moves over the stream below. Passing through the vegetation, the viewscape of Morningside Avenue and the Farm beyond is revealed. Continuing along the pathway, the viewscape is hidden again as the pedestrian moves back over the stream and through the vegetation. The stillness amongst the foliage is contrasted with the openness of the pathway by moving out of the protected space to meet the seemingly infinite Research Fields extending to the west.
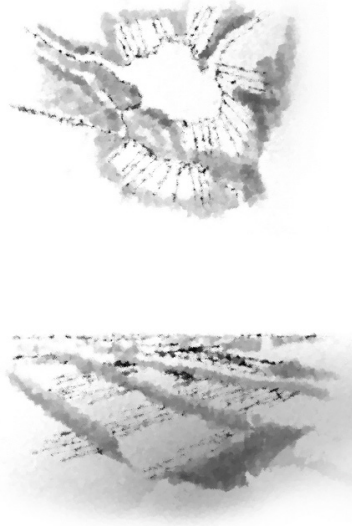

FIGURE 15

The River and the Shelterbelt. 


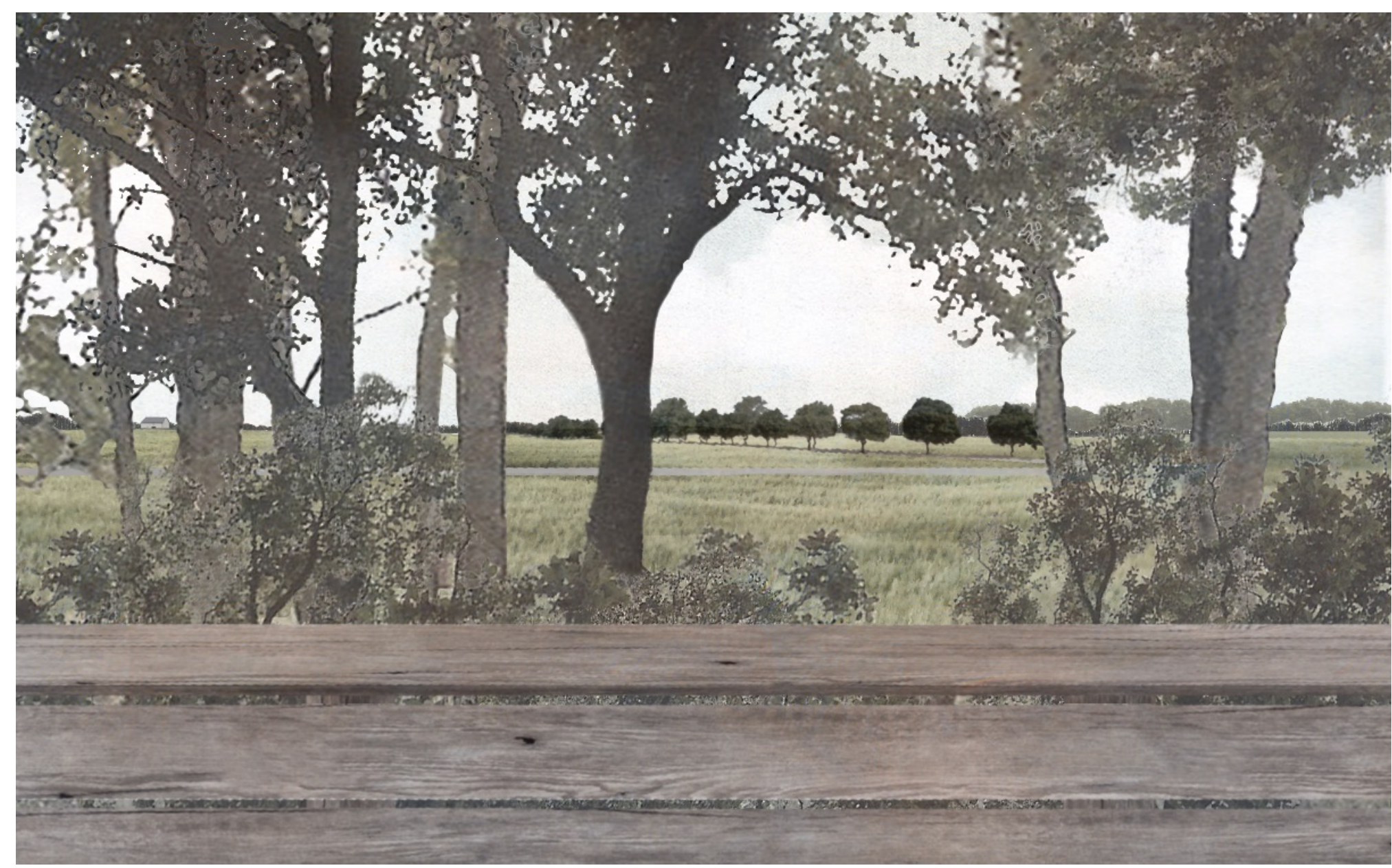

| FIGURE 16

Perspective amongst the vegetation looking north-east towards Morningside Drive. 


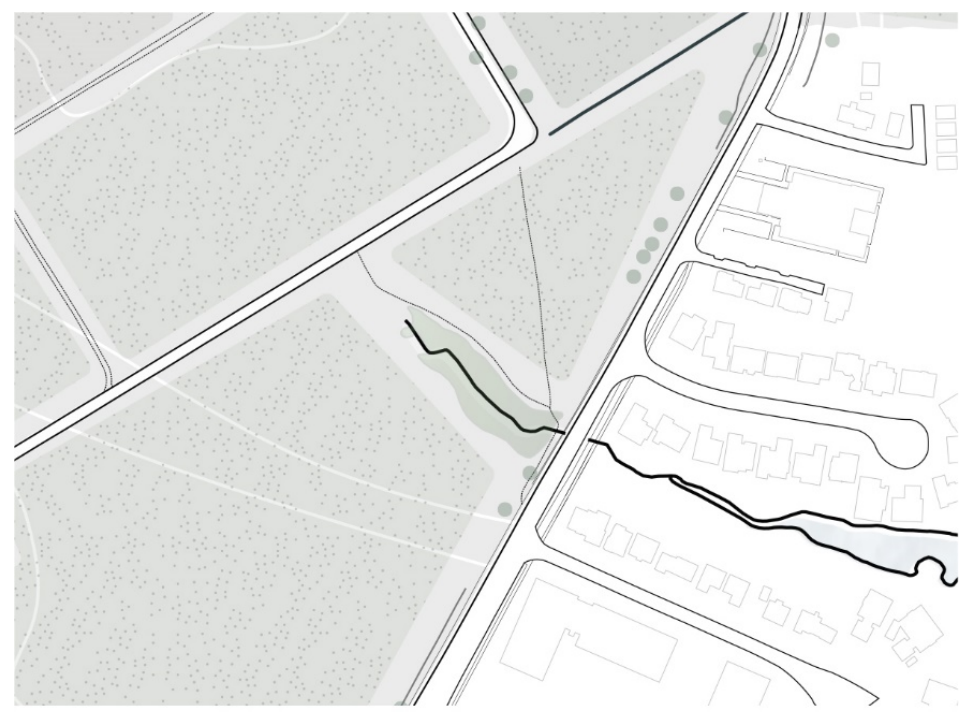

| FIGURE 17

Top: Existing Conditions, Middle:

Proposed Memory, Bottom:

Proposed Pathways.
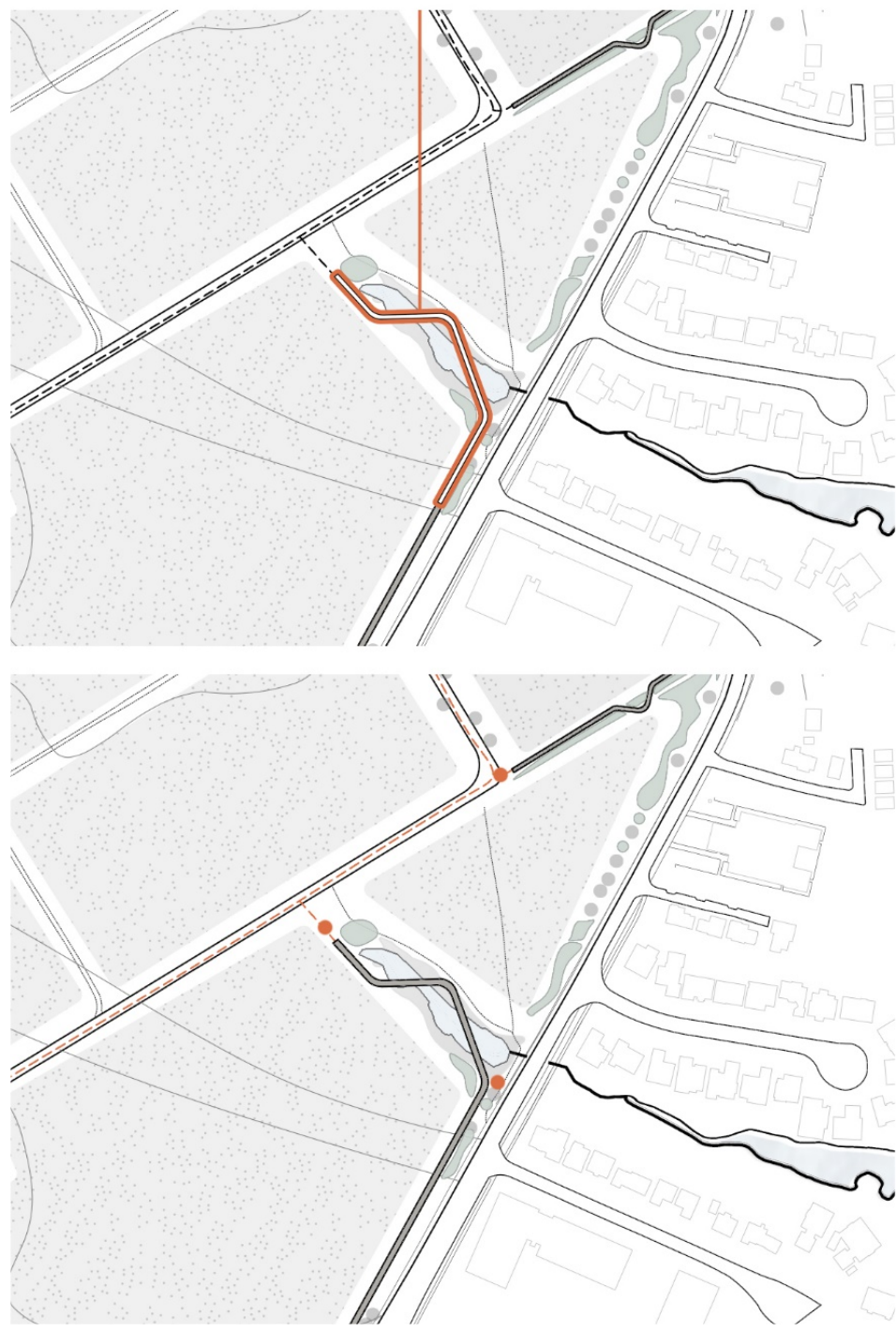


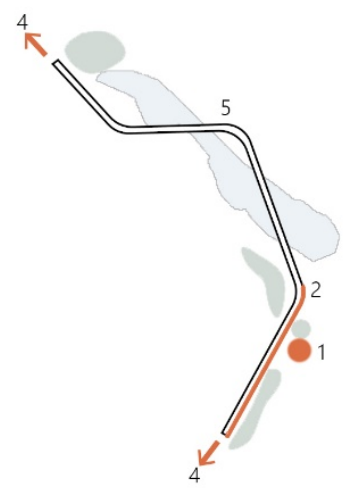

forces

1 pedestrian entry points

2 fence edge

3 protection from salt spray

4 connection to pathway network

5 pedestrian rest spots

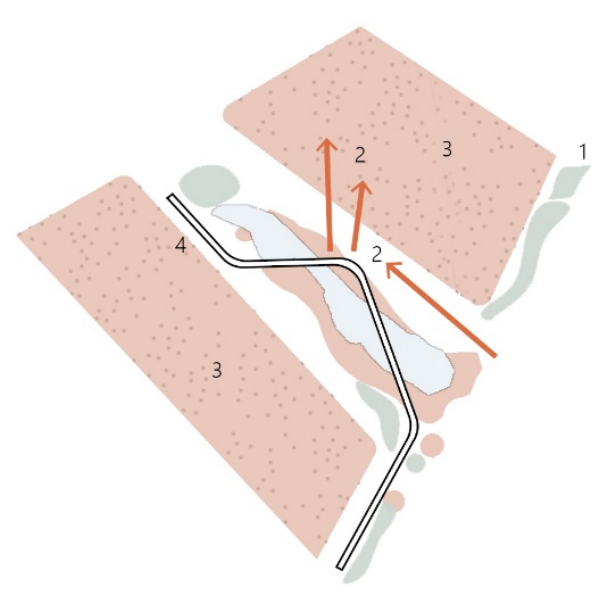

defining characteristics

1 shelterbelts

2 viewscapes

3 variety of seasonal textures

4 rectilinear planning of research fields

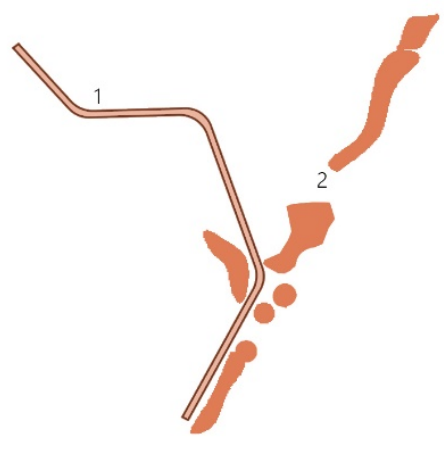

memory

2 shelterbelt 

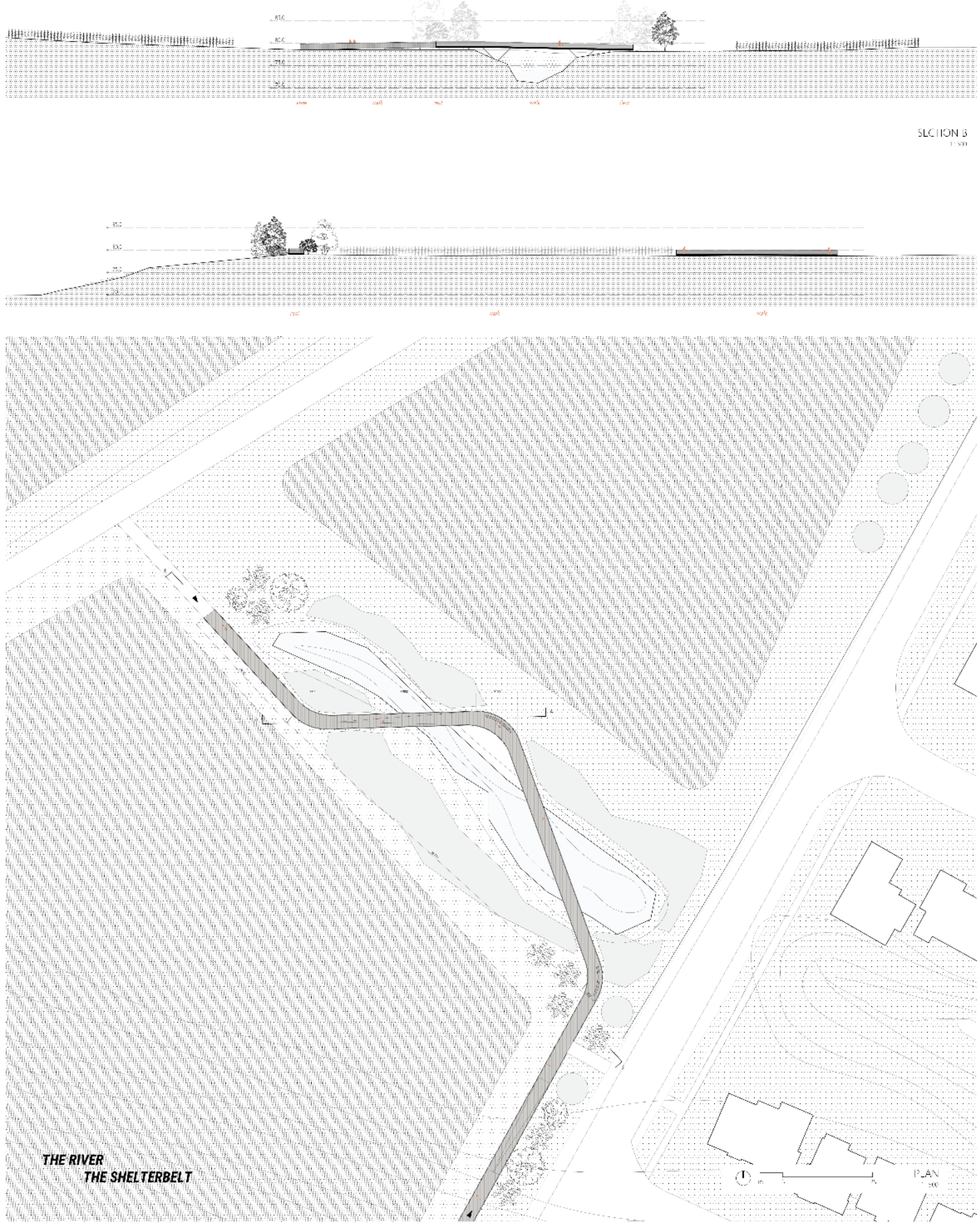


\section{Conclusion}

This thesis asks the question:

How can architecture be employed to protect both the scientific research and national historic significance of the Central Experimental Farm in the present time and for future generations, while simultaneously expressing the tangible and intangible memory of the site?

By looking at the question in terms of forces affecting the place, its character defining elements, and memories which recall the agricultural history of the lands which make up Canada, a design had been proposed to strengthen the Farm's position in the city. By harnessing the dynamic and immediate experience of the pedestrian with the landscape, the proposal seeks to move beyond the windshield of the car to experience the Farm through the engaging eyes of the walker. Utilizing inspiration from the procession of uninterrupted vehicular parkways which connect Federal sites throughout the Capital of Ottawa, the design builds upon the serendipitous result of this parkway system: the picturesque pedestrian pathways which border these parkways and continue beyond these federal sites further into the Capital region.

To provide an appropriate design proposal for the Farm, this thesis begins by first understanding landscapes as they relate to our evolving culture, as well as our role in conserving landscapes of historic value. Secondly this thesis investigates the Dominion Experimental Farm System at a national level, recognizing the role and legacy of the system in expanding agricultural production throughout the arable lands of Canada. While acknowledging the research and techniques developed by the Farm to make the expansion of agriculture across the country possible, investigating the agriculture landscapes and management of the land before Canada is vital to understand the peoples and their cultures which have formed the country. In addition, this thesis asks what are the memories of these agricultural landscapes. Concluding that an acknowledgement of the diverse and varied techniques and strategies of land management by different cultures are of significance to a place which celebrates the National system and legacy of agriculture.

At the context of the city and of the Farm, the research explores the history of the landscape from the Natural landscape, to the Inhabited landscape, to the permanently Settled landscape, as well as the evolution of cultural landscape from Designed, to Evolved, to Associative landscape. Key to the investigation of the Farm's context is the determination of its heritage value and character defining elements which emphasise the Farm's original 
planning as a picturesque landscape and evolution as an agricultural research landscape surrounded by an urban National Capital. At a city-wide scale the design extends existing pedestrian pathways into the site and make accessible the centre of the Farm from the peripheries.

The five designed nodes which provide entrance and begin the procession into the scientific landscape are represent the memories of the agriculture which have shaped the landscape. They include: the clearing, the grave, the forest, the meadow, the passage, the river, the shelterbelt, and the swamp. The simple terms are not meant to recreate a history of the agricultural landscape, but rather provide a venue into which the pedestrian can further interpret and find connection with in the Farm's landscape.

As determined in the through the investigation of place and identity early in the thesis, it was determined that our identities of place are formed through the activities of our everyday. Everyday the landscape extends beyond our eyes, into our minds, and becomes a part of who we are. These everyday experiences of walking, jogging, driving past the Farm and enjoying the scenery and glimpse of openness within the city, are ordinary, but are ordinarily sacred experiences which forms who we are. The Central Experimental Farm is an rare sanctuary within the Capital of Ottawa, and should be protected and celebrated for the enjoyment of today and future generations. 


\section{Bibliography}

LECTURES

McKay, Randall, Louis-Martin Levac, and Richard Scott. "Parks Planning, Inside and Out." Lecture, Capital Urbanism Lab Lecture Series, Capital Urbanism Lab, Ottawa, March 9, 2017.

Miguelez, Alain. "The Gréber Plan: 65 Years Later." Lecture, Heritage Ottawa Lecture Series, Dominion-Chalmers United Church, Ottawa, December 13, 2016

\section{MEDIA RELEASES AND NEWSPAPER ARTICLES}

Payne, Elizabeth "Cleanup costs for new Sir John Carling hospital site in the millions." Ottawa Sun. Accessed March 23, 2017.

http://www.ottawasun.com/2017/03/22/cleanup-costs-for-new-sirjohn-carling-hospital-site-in-the-millions.

Jones, Eric. "Friends of the Farm Presidents Warn of Development Creep." Friends of the Central Experimental Farm (Ottawa), November 13, 2014.

"The Canadian Society of Landscape Architects (CSLA) respectfully requests that landscape architects be involved in any proposed Ottawa Hospital development on the Central Experimental Farm lands." Carol Craig, AALA, FCSLA President, CSLA to The Hon. John Baird, P.C., M.P. December 12, 2014. Ottawa.

"The Coalition to Protect the Central Experimental Farm National Historic Site of Canada." The Coalition to Protect the Central Experimental Farm National Historic Site of Canada to Lawrence MacAulay, Catherine McKenna, and Mélanie Joly. November 23, 2015. Ottawa.

Rice, Waubgeshig. "Strip of Central Experimental Farm could be lost to Baseline rapid transit corridor." CBC News. February 01, 2017. Accessed February 04, 2017. http://www.cbc.ca/news/canada/ottawa/baseline-rapid-transitexperimental-farm-expropriation-1.3960257.

Tasker, John Paul. "Historic land deal with Algonquin peoples signed by federal, Ontario governments." CBCnews. October 18, 2016. Accessed March 11, 2017. http://www.cbc.ca/news/politics/ottawaontario-algonquin-agreement-in-principle-1.3809876.

Tom Spears. "Explained: What actually happens at the Experimental Farm." Ottawa Citizen. November 13, 2015. Accessed January 30, 2017. http://ottawacitizen.com/news/local-news/low-profileexperimental-farm-reveals-its-science-side. 


\section{PRINT SOURCES}

Anstey, T. H. One Hundred Harvests: Research Branch, Agriculture Canada, 1886-1986. Ottawa: Minister of Supply and Services, 1986.

"A Québec Case Study in the Repurposing of Declining Cultural Landscapes." APT Bulletin, Special Issue on Cultural Landscapes: A Tribute to Susan Buggey 47, no. 2/3. Accessed March 4, 2017. http://www.jstor.org/stable/43901890.

Berger, Markus, and Liliane Wong. Interventions/Adaptive Reuse, Difficult Memories: Reconciling Meaning. Providence: Department of Interior Architecture, Rhode Island School of Design, 2013.

Blankenship, Jeffrey D. "Reading Landscape: Mid-Century Modernism and the Landscape Idea" PhD diss., University of University of Massachusetts Amherst, 2011. http://scholarworks.umass.edu/open_access_dissertations/324

Cameron, Christina. "The Spirit of Place: The Physical Memory of Canada." Journal of Canadian Studies, Spring 2000, 77-94.

Canada. Farm Credit Canada. Canadian Agriculture and Agri-food in the Global Economy 2013-2014. Ottawa: Farm Credit Canada, 2015.

Criteria, General Guidelines, Specific Guidelines: For Evaluating Subjects of Potential National Historic Significance. Ottawa: Historic Sites and Monuments Board of Canada, Spring 2008.

Elliott, Bruce S. The City Beyond: A History of Nepean, Birthplace of Canada's Capital, 1792-1990. Nepean, Ontario: City of Nepean, 1991.

Fowler, P. J. World Heritage Cultural Landscapes, 1992-2002. Article 1. Paris: UNESCO World Heritage Centre, 2003.

Gréber, Jacques. General Report Submitted to the Nation Capital Planning Committee. Ottawa: National Capital Planning Service Ottawa, 1949.

Groth, Paul E., and Todd W. Bressi. Understanding Ordinary Landscapes. New Haven: Yale University Press, 2015.

Hanna, Beth. "Voices of the Landscape." Heritage Matters, Heritage Trust Ontario 14, no. 2 (September 2016).

Hinchcliff, Richard. Blooms: an illustrated history of the ornamental gardens at Ottawa's Central Experimental Farm. Ottawa, Ontario: Sanderling Press, 2016.

Hubbard, P., R. Kitchen, and G. Vallentine. Key Texts in Human Geography, 43-51. London: Sage, 2008.

Illustrated Historical Atlas Carleton County. Toronto: H. Beldon \& Co., 1879. Jackson, John Brinckerhoff. Discovering the Vernacular Landscape. New Haven: Yale University Press, 2009.

Longstreth, Richard W. Cultural Landscapes: Balancing Nature and Heritage in Preservation Practice. Minneapolis: University of Minnesota Press, 2008.

Mackey, Eva. "'Death by Landscape" Race, Mature, and Gender in Canadian National Mythology." Canadian Woman Studies / Les Cahiers De La Femme 20, no. 2 (Summer 2000), 125-130. 
Mann, Charles C. 1491: New Revelations of The Americas Before Columbus. New York: Knopf, 2012.

Relph, Edward. Place and Placelessness. London: Sage, 1976.

Sauer, Carl O. The Morphology of Landscape. Berkeley: University of California Press, 1925.

Schama, Simon. Landscape and Memory. London: HarperCollins, 1995.

Smith, Helen, and Mary Bramley. Ottawa's Farm: A History of the Central Experimental Farm. Burnstown, Ontario: General Store Pub. House, 1996.

Taylor, Ken. "Landscape and Memory." Paper presented the UNESCO Third International Memory of the World Conference, Australia, February 19-22, 2008.

Waugh, F. W. Iroquis Foods and Food Preparation. Honolulu, HI: University Press of the Pacific, 2003.

Williams, Ron. Landscape Architecture in Canada. Montreal: McGill-Queen's University Press, 2014.

Wilson, Chris, and Paul E. Groth. Everyday America: Cultural Landscape Studies after J.B. Jackson. Berkeley: University of California Press, 2003.

Wright, Janet. Architecture of the Picturesque in Canada. Ottawa: Ministère des Approvisionnements et services., 1984.

Report of the Select Standing Committee on Agriculture and Colonization of the House of Commons, Second Session, Sixth Parliament. Ottawa: Queen's Printer, 1888.

\section{ONLINE SOURCES}

Agriculture and Agri-Food Canada; Government of Canada. "2017 Canadian Agricultural Outlook." Agriculture and Agri-Food Canada; Government of Canada. February 17, 2017. Accessed February 20, 2017. http://www.agr.gc.ca/eng/about-us/publications/economicpublications/2017-canadian-agriculturaloutlook/?id=1487174231571.

Black, Meredith Jean. "Algonquin." The Canadian Encyclopedia. Accessed March 03, 2017. http://www.thecanadianencyclopedia.ca/en/article/algonquin/.

Central Experimental Farm Integrated Services; Agriculture and Agri-Food Canada; Government of Canada. "Central Experimental Farm National Historic Site Management Plan (9 of 20)." Central Experimental Farm Integrated Services; Agriculture and Agri-Food Canada; Government of Canada. August 05, 2015. Accessed January 03, 2017. http://www.agr.gc.ca/eng/about-us/offices-andlocations/central-experimental-farm/about-the-centralexperimental-farm/central-experimental-farm-national-historicsite-management-plan-1-of-20/central-experimental-farmnational-historic-site-management-plan-9-of20/?id $=1170436212725$. 
Central Experimental Farm Integrated Services; Agriculture and Agri-Food Canada; Government of Canada. "About the Central Experimental Farm." Central Experimental Farm Integrated Services; Agriculture and Agri-Food Canada; Government of Canada. December 23, 2015. Accessed December 2, 2016. http://agr.gc.ca/eng/aboutus/offices-and-locations/central-experimental-farm/about-thecentral-experimental-farm/?id=1169564397864.

Centre, UNESCO World Heritage. "Cultural Landscapes." World Heritage Centre. Accessed January 02, 2017. http://whc.unesco.org/en/culturallandscape/\#1.

"Central Experimental Farm." PFS Studio. Accessed January 02, 2017. http://pfsstudio.com/project/central-experimental-farm/.

ECORC; Agriculture and Agri-Food Canada;Government of Canada. "Ottawa Research and Development Centre." ECORC; Agriculture and Agri-Food Canada; Government of Canada. February 18, 2016. Accessed February 02, 2017. http://www.agr.gc.ca/eng/scienceand-innovation/research-centres/ontario/ottawa-research-anddevelopment-centre/?id=1180546650582.

Government of Canada, Treasury Board of Canada, Secretariat, Treasury Board of Canada Secretariat, Expenditure Management, Departmental Performance Reports, 2006-07 Departmental Performance Reports. "Agriculture and Agri-Food Canada." November 01, 2007. Accessed March 30, 2017. http://www.tbssct.gc.ca/dpr-rmr/2006-2007/inst/AGR/AGR01-eng.asp.

"HistoricPlaces.ca." HistoricPlaces.ca - HistoricPlaces.ca. Accessed January 02, 2017. http://www.historicplaces.ca/en/rep-reg/placelieu.aspx?id=13811.

Inside Ottawa Valley, "When continents collide our valley was formed." Inside Ottawa Valley. June 19, 2014. Accessed March 15, 2017. http://www.insideottawavalley.com/opinion-story/4587936-whencontinents-collide-our-valley-was-formed/.

Jones, Stephen Morgan. "Agricultural Research Stations." The Canadian Encyclopedia. Accessed December 2, 2016.

http://www.thecanadianencyclopedia.ca/en/article/agriculturalresearch-stations/.

Laucius, Joanne. "Planting the seed: Group aims to break ground for national botanical garden in 2017." Ottawa Citizen, June 16, 2016. http://ottawacitizen.com/news/local-news/planting-the-seedgroup-aims-to-break-ground-for-national-botanical-garden-in2017.

Plan for Canada's Capital, 2017-2067: Public Consultation Report Summer 2016. Ottawa: CNN / NCC, 2016, accessed February 04, 2017. http://www.ncc-ccn.gc.ca/sites/default/files/pubs/08.1_2017-p68e__appendix_3_-_pfcc_public_consultation_report.pdf, 38.

Parks Canada Agency, Government of Canada. "Parks Canada - Historic Sites and Monuments Board of Canada - The Evaluation Criteria of the National Commemoration Program." Parks Canada - Historic Sites and Monuments Board of Canada - The Evaluation Criteria of 
the National Commemoration Program. January 10, 2011. Accessed

November 10, 2016. http://www.pc.gc.ca/clmhc-hsmbc/ncp-

pcn/evaluation.aspx.

Parks Canada Agency, Government of Canada. "Parks Canada - National

Historic Sites - National Historic Sites." Parks Canada - National

Historic Sites - National Historic Sites. February 14, 2017. Accessed

March 02, 2017. http://www.pc.gc.ca/eng/progs/lhn-

nhs/index.aspx.

"Preservation Brief 36: Protecting Cultural Landscapes: Planning, Treatment and Management of Historic Landscapes." National Parks Service.

Accessed December 01, 2016. https://www.nps.gov/tps/how-topreserve/briefs/36-cultural-landscapes.htm.

"Quebec City Declaration on The Preservation of The Spirit of Place."

Quebec 2008 ICOMOS. Accessed March 15, 2017.

http://quebec2008.icomos.org/en/99_intro_blog.htm.

"Recommendation on the Historic Urban Landscape, including a glossary of definitions." Recommendation on the Historic Urban Landscape, including a glossary of definitions. Accessed February 02, 2017.

http://portal.unesco.org/en/ev.php-

URL_ID $=48857 \&$ URL_DO=DO_TOPIC\&URL_SECTION=201.html.

The Florence Charter. London: ICOMOS UK, 1981. 